\author{
UNIVERSIDADE DE SÃO PAULO \\ ESCOLA DE COMUNICAÇÃO E ARTES \\ PROGRAMA DE PÓS-GRADUAÇÃO EM MÚSICA
}

Riane Benedini Curi

\begin{abstract}
A análise de performances como forma de análise para a performance: um estudo de caso - Syrinx de Debussy
\end{abstract}




\author{
UNIVERSIDADE DE SÃO PAULO \\ ESCOLA DE COMUNICAÇÃO E ARTES \\ PROGRAMA DE PÓS-GRADUAÇÃO EM MÚSICA
}

Riane Benedini Curi

\title{
A análise de performances como forma de análise para a performance: um estudo de caso - Syrinx de Debussy
}

versão corrigida

(versão original disponível na biblioteca da ECA)

\begin{abstract}
Dissertação de Mestrado, submetida ao Programa de Pós-Graduação em Música da ECA/USP, Área de Concentração: Musicologia, Linha de Pesquisa: Teoria e Análise Musical, sob orientação do Prof. Dr. Rodolfo Coelho de Souza.
\end{abstract}


Autorizo a reprodução e divulgação total ou parcial deste trabalho, por qualquer meio convencional ou eletrônico, para fins de estudo e pesquisa, desde que citada a fonte.

Catalogação na Publicação Serviço de Biblioteca e Documentação

Escola de Comunicações e Artes da Universidade de São Paulo

Dados inseridos pelo(a) autor(a)

Curi, Riane Benedini

A análise de performances como forma de análise para a

performance: um estudo de caso - Syrinx de Debussy / Riane

Benedini Curi ; orientador, Rodolfo Coelho. -- São Paulo,

2021.

131 p.: il.

Dissertação (Mestrado) - Programa de Pós-Graduação em Música

- Escola de Comunicações e Artes / Universidade de São Paulo.

Bibliografia

Versão Corrigida

1. análise da performance 2. análise para performance 3 .

análise de gravações 4. Syrinx de Debussy I. Coelho, Rodolfo

II. Título.

CDD 21.ed. - 780 
A análise de performances como forma de análise para a performance: um estudo de caso - Syrinx de Debussy

Dissertação apresentada ao Programa
de Pós-Graduação em Música da
Escola de Comunicações e Artes da
Universidade de São Paulo, como
requisito parcial para obtenção do título
de Mestrado em Música.

Banca examinadora

Prof. Dr. Rodolfo Coelho de Souza

Universidade de São Paulo (USP)

$\overline{\text { Prof(a). Dr(a) Cássia Carrascoza Bomfim }}$

Universidade de São Paulo (USP)

Prof. Dr. Augusto Vieira da Silva

Universidade Estadual do Paraná (UNESPAR) 


\section{Agradecimentos}

Agradeço primeiramente ao meu marido, Daniel Catoia Quintiliano, pelo incentivo e pela ajuda sempre, não só na elaboração deste trabalho, como em todas as áreas da vida. Agradeço à minha mãe por ter me proporcionado todos os meios para que eu tivesse uma boa educação e formação e por último, mas não menos importante, agradeço a todos os professores que passaram por minha vida por terem me ajudado a formar o campo de conhecimento necessário para que eu chegasse aqui. 


\section{Resumo}

Este trabalho propõe o uso de análises da performance, mais especificamente a análise de gravações, como meio de análise para performance. Para tal propósito, um autor foi escolhido como referência, que foi John Rink. Após um breve detalhamento de suas propostas e métodos de trabalho, foi sugerido um estudo de caso. A peça musical escolhida para ser estudada foi Syrinx, de Debussy. Em seguida foram feitas diferenciações entre análise da performance e análise para performance e seguiu-se o trabalho utilizando ambos os tipos de análises na peça escolhida.

Palavras-chave: análise para performance, análise da performance, John Rink, Syrinx. 


\begin{abstract}
This work suggest the use of analysis of performances, more specifically, analisys of recordings, as a method for analysis for performances. For this purpose, na author was chosen as reference, which was John Rink. After briefly detailing his proposals and working methods, a case study was suggested. The musical piece chosen for study was Debussy's Syrinx. Then, differentiations between analysis for performance and analysis of performances were made and the work continued by using both methods of analysis on the chosen piece.
\end{abstract}

Keywords: analysis for performance, analysis of performance, John Rink, Syrinx. 
Lista de figuras

Figura 1: edição de J. Jobert............................................................25

Figura 2: transcrição do manuscrito de Bruxelas, feita por Laurell Ewell.............27

Figura 3: comparação entre a edição de J.Jobert e o manuscrito de Bruxelas....29

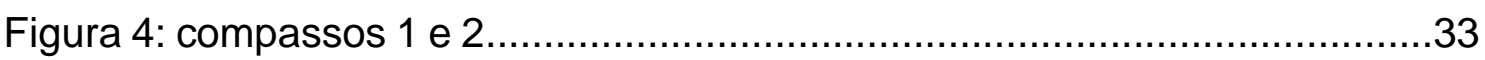

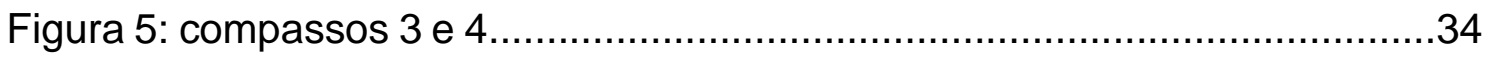

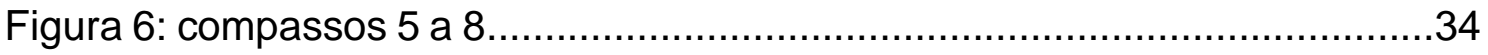

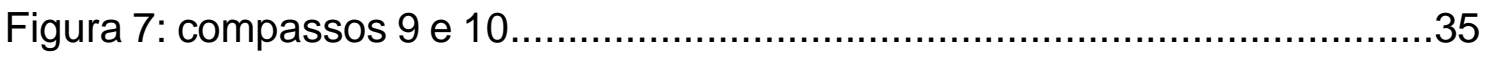

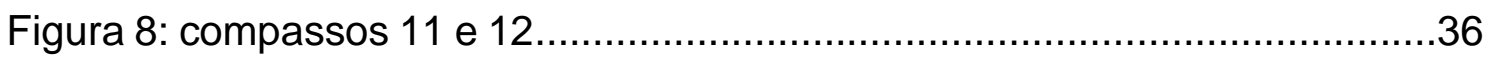

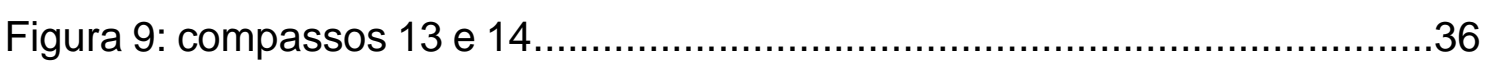

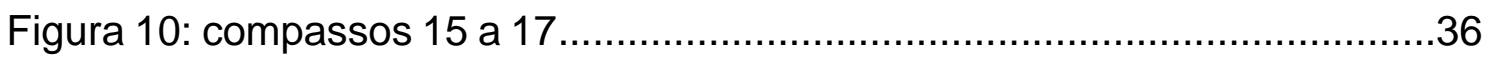

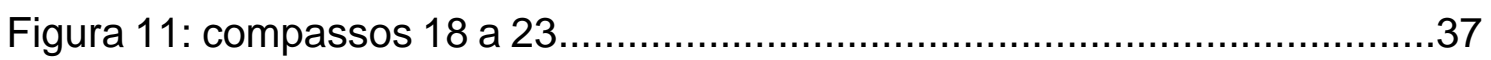

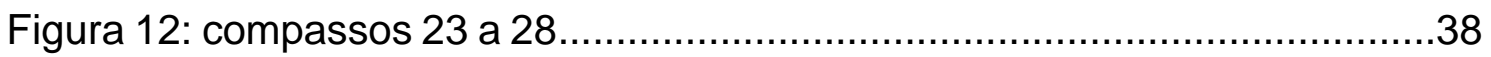

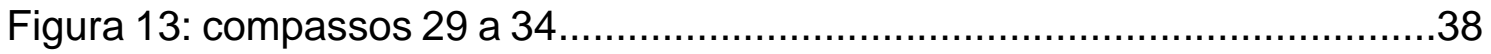

Figura 14: escalas de tons inteiros utilizadas..........................................43

Figura 15: escalas octatônicas utilizadas...............................................43

Figura 16: escalas pentatônicas utilizadas...............................................44

Figura 17: análise harmônica compassos 1 e 2 ..............................................45

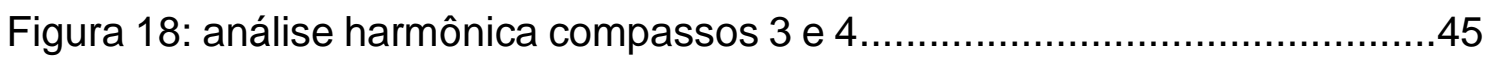

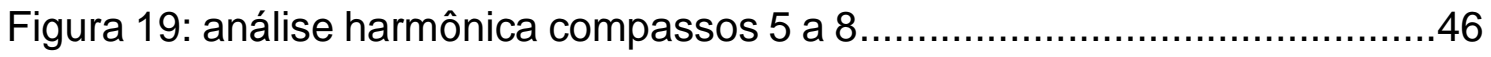

Figura 20: análise harmônica compassos 9 a 12 ...........................................46

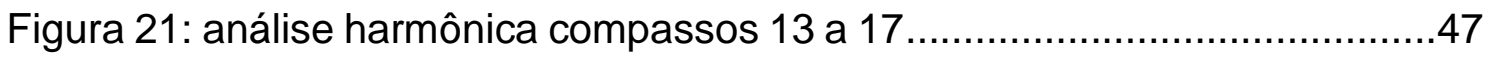

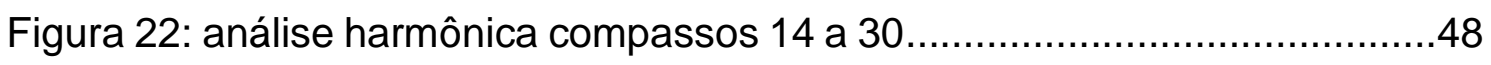

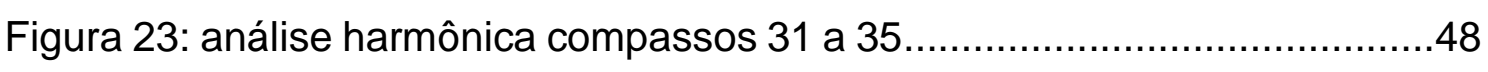

Figura 24: gráficos de tempo e dinâmica completos......................................59

Figura 25: gráficos de dinâmica e tempo com barras de compasso..................61

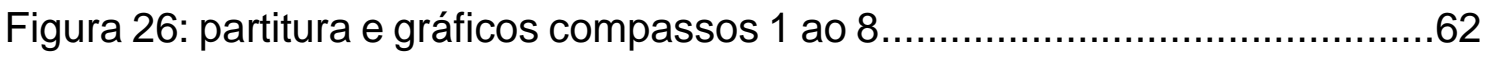

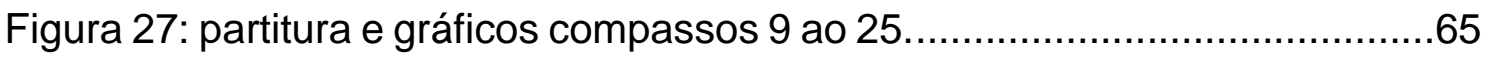

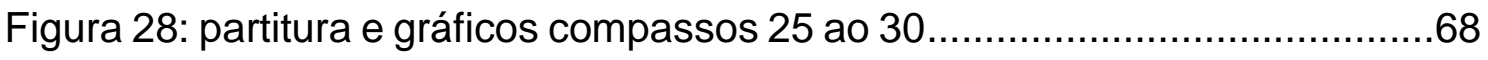

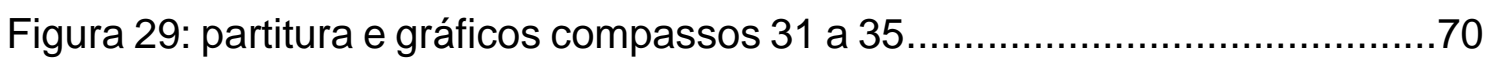

Figura 30: dinâmicas presentes em Syrinx.............................................. 72

Figura 31: gráfico gravação 1 com barras de compasso .................................73 
Figura 32: gráfico gravação 2 com barras de compasso ..................................74

Figura 33: gráfico gravação 3 com barras de compasso...................................75

Figura 34: gráfico gravação 4 com barras de compasso..................................77

Figura 35: gráfico gravação 5 com barras de compasso...................................78

Figura 36: partitura e gráficos compassos 1 e 2............................................

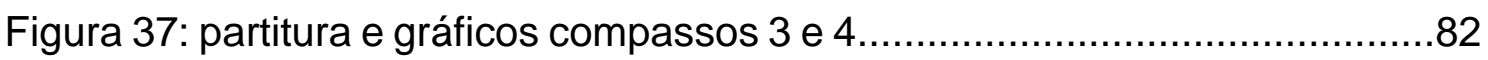

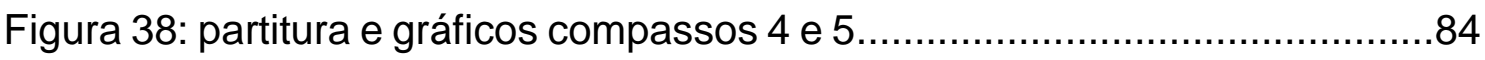

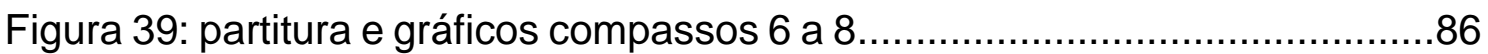

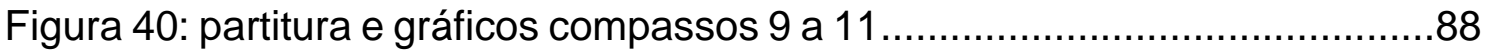

Figura 41: partitura e gráficos compassos 11 e 12.......................................90

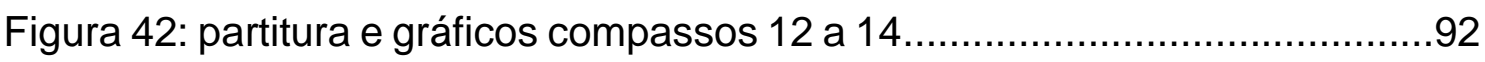

Figura 43: partitura e gráficos compassos 14 a 16...........................................

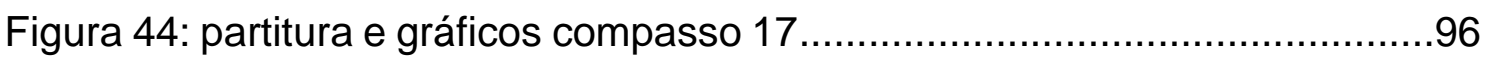

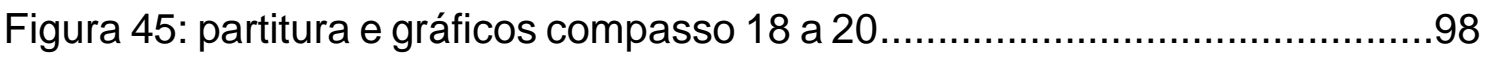

Figura 46: partitura e gráficos compasso 20 e 21.......................................100

Figura 47: partitura e gráficos compassos 22 e 23......................................102

Figura 48: partitura e gráficos compassos 23 a 25.........................................104

Figura 49: partitura e gráficos compassos 25 e 26......................................106

Figura 50: partitura e gráficos compassos 27 e 28.......................................108

Figura 51: partitura e gráficos compassos 29 e 30.....................................110

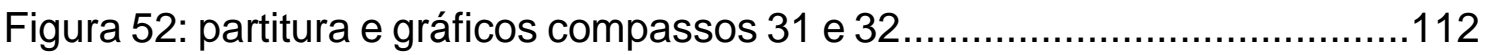

Figura 53: partitura e gráficos compassos 33 a 35......................................114 
Lista de tabelas

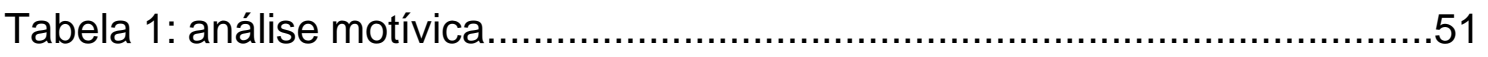

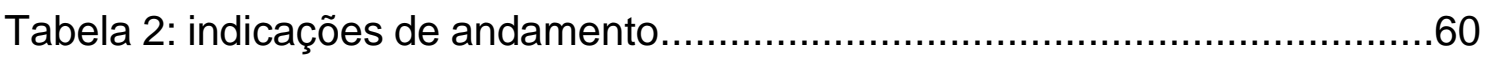

Tabela 3: quadro comparativo entre as gravações........................................116 
Sumário

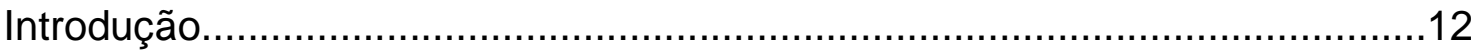

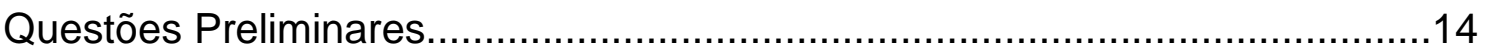

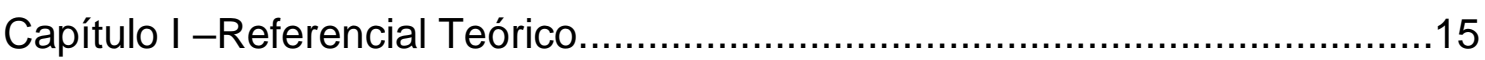

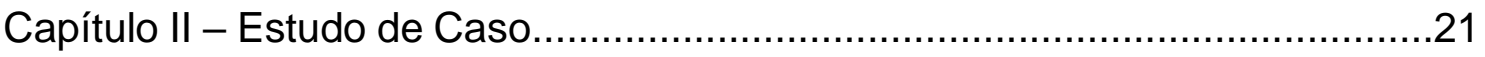

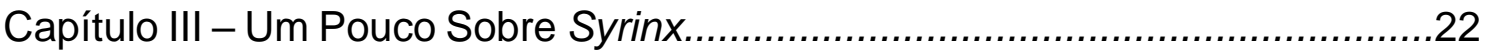

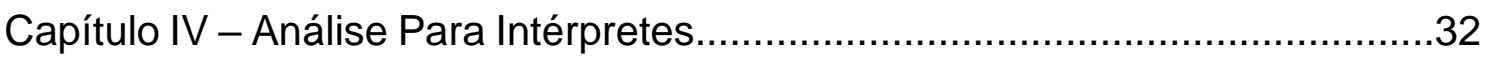

Capítulo V - Análise Harmônica...................................................................

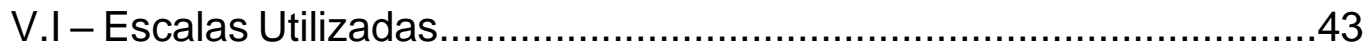

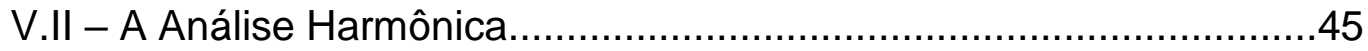

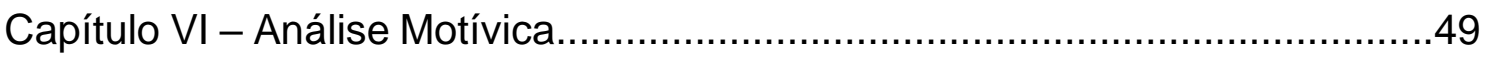

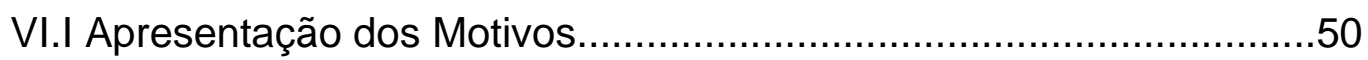

VI.II A Análise Motívica.........................................................................51

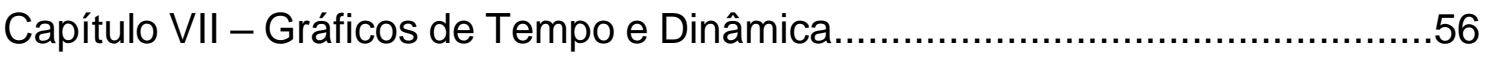

VII.I - Análise dos Gráficos em Relação à Tempo...................................59

VII.II - Análise dos Gráficos em Relação à Dinâmica................................72

Capítulo VIII - Quadro Comparativo entre as Gravações................................116

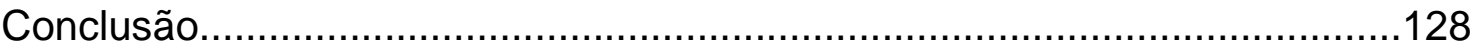

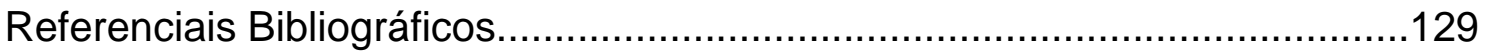




\section{Introdução}

A prática musical é uma atividade inerente ao ser humano, integrada à cultura universal e praticamente uma necessidade biológica (DUNSBY apud RINK, 2012), mas, apesar dessa universalidade, a performance musical é notoriamente resistente a explicações (RINK, 2018) e há uma crescente necessidade de uma perspectiva mais global no estudo da performance (RINK, 2012).

Uma performance depende de decisões, decisões que formulam o meio que o intérprete vai mostrar aspectos contidos na música. Essas decisões podem ser completamente intuitivas ou podem ter sido tomadas de forma analítica (RINK, 2007). Existem diversas formas de análises e "toda descoberta analítica influencia de alguma forma a performance." (BERRY apud RINK, 2007, p. 26). O intérprete, portanto, "enquanto cocriador, deveria adquirir competência teórica e analítica para saber como interpretar" (NARMOUR apud RINK 2007, p. 26), pois, "a análise está implícita na atuação do intérprete" (MEYER apud RINK 2007, p. 25).

As observações analíticas, no entanto, não impõem uma única e definitiva opção interpretativa (SCHMALFELDT apud RINK 2007), pois a interpretação pessoal reelabora uma obra de arte indefinidamente e isto é o que a faz reviver (GENTILE apud ABDO 2000). A análise poderia ser vista, então, como uma forma de auxiliar na resolução de problemas específicos da interpretação, fornecendo caminhos, sugestões e princípios pelos quais a execução pode ser informada (WINTER / SILVEIRA 2006).

Existem diversas formas de análise relacionadas à performance e a maior diferenciação existente entre elas, segundo J. Rink, é entre o que ele chama de a análise anterior e alguns autores chamam de análise para performance e a análise da performance. A análise para performance, mesmo sendo rigorosa ou pragmática, seria prescritiva e serviria como base para uma performance (RINK, 2007). Já a análise da performance seria uma análise descritiva que pode ser feita tanto em performances ao vivo quanto gravadas e que "constitui uma maneira diferente de se determinar 'o que aconteceu"' (RINK, 2012, p.39). A análise de gravações é, então, uma das formas de análise da performance e J. 
Rink reconhece a crescente importância das gravações como fonte de estudo para prática de performance (RINK, 2001, p. 435). Também afirma que os intérpretes costumam ouvir gravações de si próprios em busca de aspectos para serem melhorados e aprimorados. Porém, ainda em relação a gravações, também diz que, apesar de serem um meio concreto e acessível para vivenciar performances, são como fotografias em relação à eventos reais: não captam a totalidade dos eventos presentes (RINK, 2018).

"O desafio do intérprete-analista é decidir quais conclusões devem ser extraídas da análise e conectá-las com os procedimentos interpretativos e de execução." (WINTER / SILVEIRA 2006, p. 70). 


\section{Questões preliminares}

Apesar de haver essa diferenciação entre análise para performance e análise da performance, ambas acabam essencialmente se convergindo. A análise da performance, de certa forma, depende da análise para performance: quando performances são analisadas, são testadas hipóteses que foram feitas à priori, criadas ou descobertas através da análise para performance. Agora, e o contrário? Poderiam os resultados obtidos numa análise da performance serem utilizados como base para a formação de uma nova interpretação? Em outras palavras, poderia a análise da performance ser, essencialmente, uma das muitas formas de análise para performance?

Hoje em dia, a Internet possibilita formas totalmente acessíveis de se encontrar performances de músicos de toda parte do mundo por meio de plataformas de vídeos e áudios. Poderia o intérprete, então, ter como base para a formação de sua performance comparações entre gravações diversas? Seria essa análise das performances uma forma de análise para performance?

O trabalho proposto especularia se a análise de gravações seria útil como análise para performance, formando um leque de opções que uma vez aberto, traria ao intérprete uma base com diversas possibilidades de escolha. Com o propósito de comparação, foram utilizados outros métodos de análise e, ao final, as conclusões extraídas de cada método serão comparadas. 


\title{
Capítulo I - Referencial Teórico
}

O campo das análises de performances é extremamente amplo. Entre os diversos autores que escrevem sobre o tema, destaca-se John Rink. Sua abordagem sobre análise de performances é interessante pois em nenhum momento ele tenta impor os resultados obtidos nas análises às performances. Reconhece, obviamente, a importância das análises, mas não reprime a criatividade do intérprete.

\begin{abstract}
A análise pode estar "implícita" no que o intérprete "faz", e pode também ser explicitamente adotada por intérpretes que se utilizam destas e de outras técnicas [...]. Mas é importante não alçá-la a um status mais importante do que a performance ela tenha originado, ou usá-la como um meio de subjugar e constranger os músicos. Ao contrário, sua utilidade potencial deve ser reconhecida, assim como suas limitações, com o que quero dizer simplesmente que "a música" transcende esta e qualquer outra abordagem que tenha como finalidade compreendê-la. Projetar a música é o que mais importa e todo o resto é apenas um meio para se atingir uma finalidade. (Rink, 2007 p. 42)
\end{abstract}

Sendo assim, John Rink, suas teorias e sua forma de conduzir seus trabalhos e análises serão usados como referência para este trabalho.

John Rink estudou na Princeton University, na King's College London e na University of Cambridge, onde hoje leciona Musical Performance Studies. Também é diretor de Studies in Music na St John's College. Se especializou nos campos de estudos de performance, teoria e análise e estudos do século XIX, e entre seus seis livros publicados pela Cambridge University Press, incluem-se títulos dedicados exclusivamente à análise relacionada à performance, além de diversos artigos que incluem o mesmo tema.

Apesar do termo análise gerar controvérsia, Rink afirma que a análise relacionada à performance se divide em duas principais categorias: "(1) análise anterior, possivelmente servindo de base a uma performance em particular e (2) análise da performance" (RINK, 2007, p. 27). Chamar-se-á no presente trabalho o primeiro tipo listado como análise para performance e o segundo ficará igual, 
análise da performance. A análise para performance, sendo rigorosa ou pragmática, é prescritiva, enquanto a análise da performance é descritiva (RINK, 2007). Trataremos primeiro das possíveis maneiras de análise para performance.

Os intérpretes estão sempre envolvidos em algum tipo de análise, pois uma interpretação precisa de decisões pela parte do intérprete, conscientes ou não. Alguns usam decisões intuitivas e não sistemáticas, e outros partem para uma reflexão cuidadosa dos aspectos analíticos da peça (RINK, 2007).

Para essas decisões intuitivas, Rink propõe o nome intuição informada, alegando que esse termo reconhece tanto a relevância da intuição na formação de uma performance, quanto o fato dessa intuição não surgir simplesmente do nada, e sim ser "geralmente sustentada por alguma bagagem considerável de conhecimento e experiência, designada por uma compreensão assimilada de sintaxe, estrutura melódica, padrão rítmico e assim por diante" (RINK, 2007, p. 27).

Outro nome proposto por Rink é a análise para intérpretes, que seria 0 "estudo minucioso da partitura com atenção especial às funções contextuais e aos meios de projetá-las" (RINK, 2007, p. 27). Essa análise não seria necessariamente tão profunda quanto as análises que acontecem nos meios acadêmicos, e teria como objetivo maior a comunicação do texto musical e teria algumas implicações, que são:

1- A temporalidade reside no coração da performance e é consequentemente fundamental para a análise do intérprete;

2- Seu objetivo primordial é descobrir o contorno da música, em oposição à estrutura, assim como os meios de projetá-la;

3- A partitura é "a música", "a música" não se restringe à partitura;

4- Qualquer elemento analítico que se impõe na performance será idealmente incorporado numa síntese mais geral, influenciado por considerações sobre estilo (definido amplamente), gênero, tradição de performance, técnica, instrumento, etc., assim como pelas prerrogativas individuais do intérprete. Em outras palavras, decisões determinadas pela análise não devem ser sistematicamente priorizadas;

5- A "intuição informada" guia, ou ao menos influencia, o processo da "análise para intérpretes", embora uma abordagem mais 
deliberadamente analítica possa ser igualmente útil (RINK, 2007, p. 29).

Rink enfatiza o fato que esse tipo de análise acontece geralmente no estado evolutivo de uma interpretação: enquanto estamos estudando uma peça, formulando uma interpretação e reavaliando nossas decisões. Mas que isso não diminui sua importância e influência numa execução propriamente dita, pois as descobertas feitas assim são "assimiladas na bagagem geral de conhecimento que sustenta, mas não domina, o ato da performance" (RINK, 2007, p. 29).

A análise mais rigorosa consistiria no aprendizado de técnicas que não necessariamente seriam aplicadas diretamente à performance, mas sim que tivessem suas terminologias e conceitos assimilados para uma melhor capacidade de articulação do intérprete, para si mesmo e para os outros, do que acontece na música (RINK, 2007).

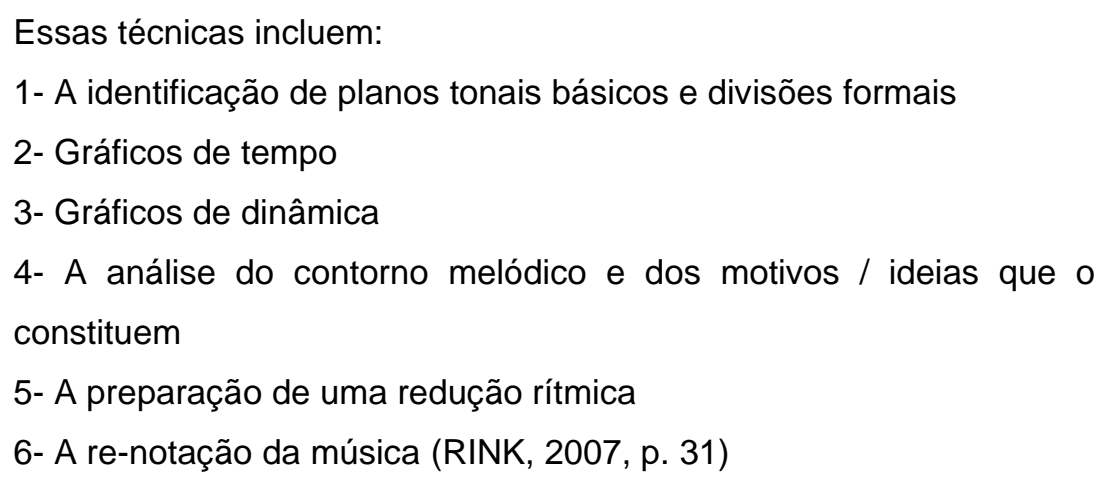

Essas técnicas seriam benéficas desde que não fossem consideradas como finalidade e sim como uma forma de...

...enriquecer a consciência do processo musical. Vale reafirmar que a temporalidade e o "contorno" são fundamentais para esta investida analítica, assim como o reconhecimento da necessidade de uma análise mais extensa (RINK, 2007, p. 31).

Ainda sobre destrinchar a partitura em busca de pistas para como se interpretar uma obra, ele afirma que apesar da escolha de um texto editado ter muitas consequências para a performance, ser estritamente fiel aos aspectos contidos na partitura é insuficiente para recriar a estética original da música e, 
ser infiel a eles, não necessariamente cria uma performance de má qualidade (RINK, 2012). Sugere, então, que a partitura seja vista como proposto por Cook: como um script e não um como texto, reorientando a relação entre notação e performance que, por muitas vezes, confunde partitura e música (RINK, 2018), pois, "por mais sofisticado que seja, nosso sistema de notação musical não consegue capturar todos os elementos de uma performance" (RINK, 2012, p. $35)$.

A escolha do texto e suas implicações aparece também quando se fala sobre a musicologia histórica. Além do estudo da partitura, que incluiria primeiras edições e manuscritos autógrafos e de copistas, Rink lista uma variedade de itens que serviriam como tópicos de investigação para os historiadores da performance que englobam muito mais do que apenas as práticas interpretativas. Questões como instrumentos remanescentes, material iconográfico, registros históricos dos mais variados tipos e tratados práticos e teóricos seriam igualmente relevantes ao estudo da partitura. A partir desses itens, então, pode-se buscar um aprofundamento em outras questões como articulação, inflexão melódica, acentuação, tempo e acentuação rítmica. Ainda há mais uma lista de implicações para o pesquisador da musicologia histórica que seria a atenção ao local usado para as apresentações, formação, recursos financeiros, mecenato, entre outros. "As investigações detalhadas de cada uma dessas evidências [...] resultaram em um monumental corpus de conhecimento acadêmico que continua a crescer e florescer" (RINK, 2012, p. 39).

Entretanto, Rink também afirma que essa busca por autenticidade que a musicologia histórica propõe é quimérica e que a presença de informações históricas numa performance, além de não garantir sua qualidade, pode não funcionar musicalmente. Seria necessário reconhecer a grande gama de fatores que estão por trás de uma performance e que the atribuem forma e resistir à tentação de dizer que um achado histórico ou um fato analítico deveriam influenciar a performance (RINK, 2012).

Aplicar os frutos das análises nas performances não é uma tarefa simples e muitos intérpretes se sentem tolhidos da liberdade que necessitam. Os musicólogos tendem a colocar a pesquisa em primeiro plano e esquecem que as performances nunca são definitivas. Originam-se prescrições doutrinárias onde conclusões analíticas deveriam ser comunicadas através do som, mesmo 
existindo a possibilidade dessas conclusões não terem absolutamente relação nenhuma com a realização temporal da música (RINK, 2012). Muitas vezes, descobertas analíticas são muito mais fascinantes e facilmente observáveis no papel (RINK, 2007).

\footnotetext{
Existe há muito tempo na musicologia uma suposição implícita, segundo a qual os acadêmicos ocupariam um patamar superior em termos de conhecimento e discernimento e que os intérpretes que não buscam assimilar avidamente os resultados dessas pesquisas em suas performances correriam o risco de se entregar a um fazer musical superficial e desprovido de sentido, que serviria apenas a eles enquanto indivíduos, ao invés de atender a um ideal mais elevado. Tal ponto de vista é insustentável e deve ser abandonado de uma vez por todas (RINK, 2012, p. 40).
}

É afirmado que as análises típicas dos trabalhos musicais tradicionais levam em conta considerações isoladas sobre a música e em oposição a isso poderia se pensar na etnomusicologia como exemplo, pois ela se concentra na performance como evento (RINK, 2012). As análises etnomusicológicas nasceram juntamente com a invenção do fonógrafo, são em parte, portanto, análise das performances, no caso, performances folclóricas. Mas, mesmo na música ocidental tradicional, "acadêmicos nos anos recentes têm se voltado cada vez mais para gravações como fonte para estudos de práticas de performances" (RINK, 2001, p. 435). A avaliação e comparação de diferentes gravações é uma forma de análise da performance.

Rink afirma que a análise da performance pode ser tanto de performances gravadas quanto ao vivo, que seu caráter é puramente descritivo e que "constitui uma maneira diferente de se determinar 'o que aconteceu'” (RINK, 2012, p.39). Pode também se utilizar de meios tecnológicos para capturar dados como oscilações de dinâmica e tempo e técnicas espectográficas. Gráficos de oscilação de dinâmica e tempo de performance gravadas e ao vivo são mostrados como exemplos das possibilidades deste tipo de análise e demonstração de como essa abordagem está de fato presente nos textos analíticos recentes (RINK, 2012 e 2007).

A importância da análise da performance é enfatizada afirmando-se que... 
...os próprios músicos normalmente analisam (ou seja, seccionam e avaliam) posteriormente suas performances, empenhando-se em descobrir formas diferentes e mais eficazes de compreender a música, visando uma próxima performance, num processo contínuo de evolução (RINK, 2007, p. 27).

Rink não cita o termo "gravação" nessa afirmação, mas pode-se concluir que essas análises que os músicos fazem de suas próprias performances são feitas através de gravações de si próprios. Se um músico se beneficia analisando suas próprias performances, pode-se concluir então que também existiriam benefícios em se analisar performances de outros músicos.

Mesmo se não estivermos ouvindo a concepção da peça que o compositor idealizou, por meio da escuta de diferentes gravações podem-se encontrar novas e distintas mensagens expressivas e, talvez, se comover de maneiras que nem o próprio compositor poderia imaginar (RINK, 2018).

"A arte envolve a habilidade de transformar a performance em algo que represente mais do que somente a soma de suas partes, incluindo as influências da história, da análise e muito mais" (RINK, 2012, p. 58). 


\section{Capítulo II - Estudo de Caso}

Em muitos de seus artigos, Rink costuma seguir um modelo: inicialmente ele apresenta diversos meios utilizados para analisar obras e performances individuais. Em seguida, se utiliza de alguns desses meios para um estudo de caso, mostrando que podem existir lacunas entre a teoria e a prática propriamente dita da análise e sugerindo modos de preenchê-las, enfatizando o que cada um dos resultados obtidos pode oferecer ao intérprete.

Rink não justifica a escolha das peças, pois, em se tratando de análise de e/ou para performance, a peça em si acaba sendo um tanto irrelevante. Porém, no caso deste trabalho, alguns quesitos foram procurados na peça a ser analisada:

1. que fosse de um instrumento solista, a fim de facilitar a visualização dos gráficos de dinâmica e tempo;

2. que tivesse nuances intencionais de tempo, sendo esse um critério a ser analisado nos gráficos;

3. que tivesse interpretações diversas, justamente procurando as diferenças que serão analisadas e...

4. que fosse relativamente curta.

A peça escolhida foi Syrinx, de Debussy. Ela se encaixa nos quesitos estipulados, além de ser parte fundamental no repertório flautístico. 


\section{Capítulo III - Um Pouco Sobre Syrinx}

O objetivo deste trabalho não é se adentrar na musicologia histórica nem criar uma performance historicamente orientada. Rink afirma que informações históricas não garantem uma performance de qualidade e que a busca por uma performance perfeitamente autêntica historicamente é uma utopia. Por outro lado, investigações sobre manuscritos autógrafos, local onde peças foram estreadas, registros históricos variados, entre outros, resultariam num bom corpus de conhecimento (RINK, 2012). Por esse motivo, serão especulados brevemente alguns aspectos sobre a peça Syrinx que podem ser relevantes para uma performance.

Na obra Metamorfoses, Ovídio conta em 15 livros a história da criação do mundo, sob o ponto de vista da mitologia greco-romana. No livro I, ele apresenta Syrinx como uma ninfa que vivia na Arcádia, seguidora da deusa Diana rainha caçadora e deusa dos bosques (BULFINCH, s/d), que sempre escapava das perseguições de sátiros, divindades dos bosques e campos com pequenos chifres e pés de cabra (BULFINCH, s/d) e deuses da floresta, conservando-se virgem. Ao ser perseguida pelo amoroso Pan, o deus dos bosques e dos campos, dos rebanhos e dos pastores, morava em grutas, amava música, vagava pelas montanhas e pelos vales e divertia-se caçando ou dirigindo a dança das ninfas (BULFINCH s/d, p. 204), Syrinx correu para as margens do rio, pedindo às suas irmãs que a ajudassem na fuga dos constantes assédios do fauno, mudando sua forma. Quando ele finalmente a alcançou e a teve em seus braços, ela já havia sido transformada em um caniço. Desiludido, Pan suspirou, produzindo assim um som suave e doce no caniço. Percebendo que tendo o caniço ele teria sua adorada ninfa, e tocado pelo maravilhoso som por ele produzido, decidiu então cortá-lo e juntar com cera os pedaços, que eram de diferentes tamanhos, fazendo assim a conhecida flauta de Pan, que ele chamou de Syrinx.

O amigo de Debussy, Gabriel Mourey, era poeta e crítico de arte. Eles tentaram trabalhar juntos por algumas vezes, e várias dessas tentativas falharam, mas, uma parceria foi completada com sucesso: o poema dramático em três atos Psyché. Segundo Anders Ljungar-Chapelon (apud EWELL, 2004, 
p. 1), o poema "reconta o mito de Psyché como contado pelo autor latino Apuleio, com a inserção da história da morte de Pan, de acordo com a versão de Plutarco, no terceiro ato". Apuleio conta uma história de amor entre Psyché, uma mortal muito bela, e Eros, mais conhecido como Cupido, onde ela tem que passar por severas provas ditadas por Vênus, ou Afrodite mãe de Eros, para no fim conseguir a imortalidade dos deuses e o eterno amor de Eros. E Plutarco, em seu livro Moralia, não dá muitos detalhes da morte de Pan, dizendo apenas que "o grande Pan está morto", e que ao ouvir essas palavras, ouviu-se o lamento não de uma, mas de uma multidão de pessoas.

De acordo com Pierre-Yves Artaud (apud D'ÁVILA s/d, p.1), todas as outras possíveis músicas feitas por Debussy para essa peça desapareceram, restando apenas Syrinx, nomeada então de La Flûte de Pan. Originalmente feita como música incidental, ela seria descritiva e tenderia a narrar uma história, mas de maneira nada explícita, gerando apenas impressões do que estaria acontecendo no palco durante sua execução, que, aliás, deveria ser feita atrás das cortinas.

O flautista que tocou na estreia da peça, em dezembro de 1913, foi Louis Fleury. Ele era professor do Conservatório de Paris, onde Debussy estudou, e um grande incentivador da música contemporânea. Fleury tocava La Flûte de Pan em seus recitais, e a partitura esteve com ele até a data de sua morte, em 1927, quando foi então editada e publicada pela Société dês Editions JOBERT, Paris (figura 1).

Foram os próprios editores que colocaram a dedicatória à Louis Fleury, como reconhecimento de sua importância na divulgação da obra, e mudaram o nome da peça para Syrinx, evitando assim possíveis confusões com uma das Chanson de Bilites que já tinha o nome de Flûte de Pan. Marcel Moyse, flautista também muito conhecido da época, foi chamado para ajudar na edição da peça, e alguns autores supõem que foi ele que colocou as marcas de respirações e as barras de compasso presentes na edição.

A edição de J. Jobert é tida como fonte primária da obra, pois a partitura original nunca foi encontrada. Porém, um manuscrito da peça foi descoberto recentemente em Bruxelas pelos pesquisadores Anders Lunjar-Chapelon e Michael Stegemann, na coleção particular da Madame Hollanders de Ouderaen, que pode ser anterior à edição de J. Jobert (figura 2). 
Michael Stegemann (apud EWELL, 2004, p. 3) conclui, após análises e comparações da caligrafia de manuscritos originais de Debussy, que o manuscrito de Bruxelas não foi feito por ele. O manuscrito pode ter sido feito pelo flautista Fleury, já que nele estão escritas a data de 1913, e algumas frases do texto da peça Psyché que indicam onde seria o momento exato de se tocar, mostrando que, talvez, foi essa a partitura que Fleury usou para tocar a obra em sua estreia.

As dúvidas sobre a autoria do manuscrito não diminuem sua importância. Nele já estão presentes as barras de compasso, o que contradiz a ideia de elas terem sido colocadas por Moyse. Não existem discrepâncias no ritmo, porém há algumas poucas diferenças entre o manuscrito de Bruxelas e a edição de $\mathrm{J}$. Jobert, que segundo Laurell Astrid Ewell são:

1) O título La Flûte de Pan em vez de Syrinx, o mesmo título que Fleury usou ao descrever essa composição em 'Music and Letters';

2) Uma inscrição indicando Act III, scéne premièr como a localização da música na peça;

3) Duas 'deixas' escritas do texto falado;

4) Três marcas de respiração diferentes da edição de Jobert;

5) Um diminuendo no compasso $34 \mathrm{em}$ vez de um acento;

6) En animant peu à peu no compasso 22;

7) Uma ligadura no compasso 3 , conectando o primeiro e o segundo tempos;

8) Marcas de dinâmica faltando nos compassos 1 e 6. (EWELL, 2004, p. 5)

A seguir, vê a edição de J. Jobert e a transcrição do manuscrito de Bruxelas completos, e em seguida, uma comparação entre ambas apenas na parte musical (as diferenças entre os títulos e as deixas escritas no manuscrito não foram consideradas nessa comparação). 


\section{Syrin $x$}

à Louis Fleury

C1. Debussy

(1913)

FLÛTE SEULE
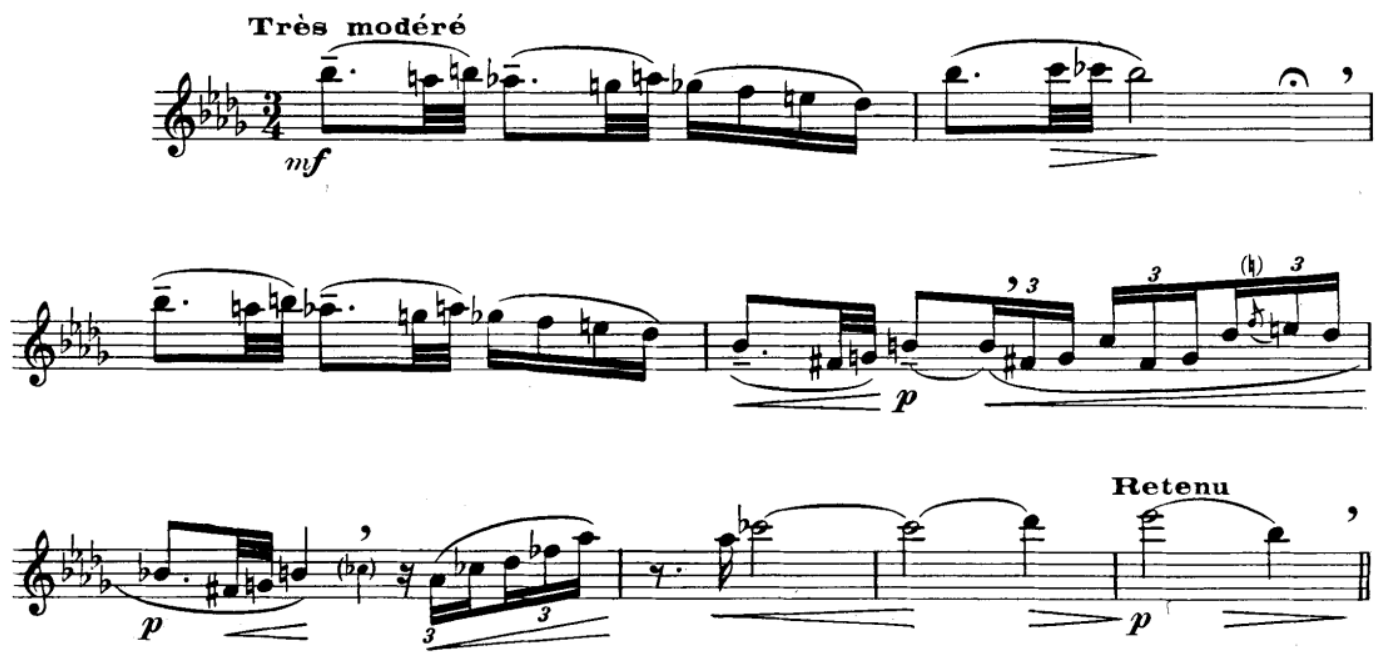

Un peu mouvementé (mais très peu)
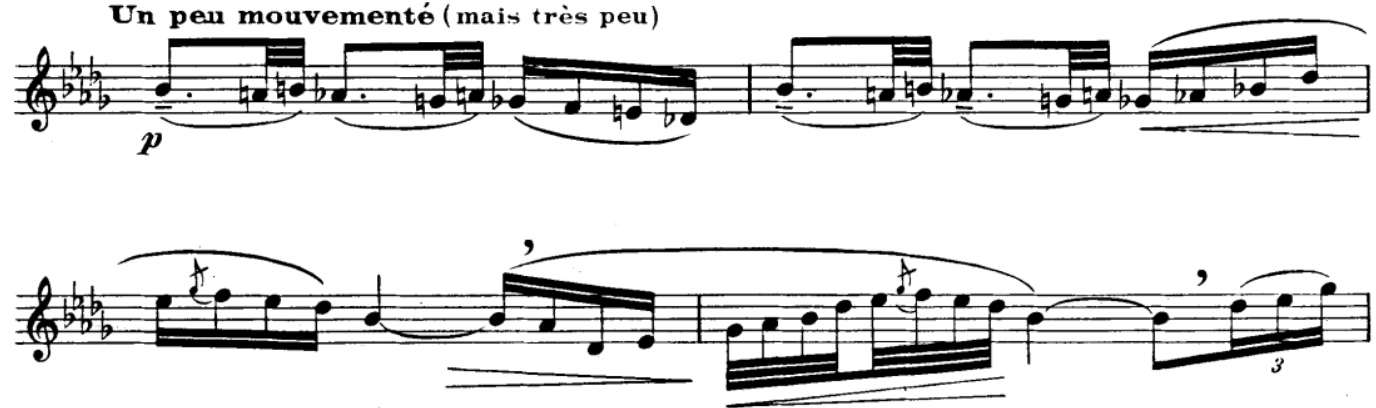

Copyrighi by J. Jobert 1927

Renouvelé 1954

Sociét'́ des Editions JOBERT

76, Kue Quincampoix

J.J. 344

Tous droits d'exécution et d'arran75003 PARIS 

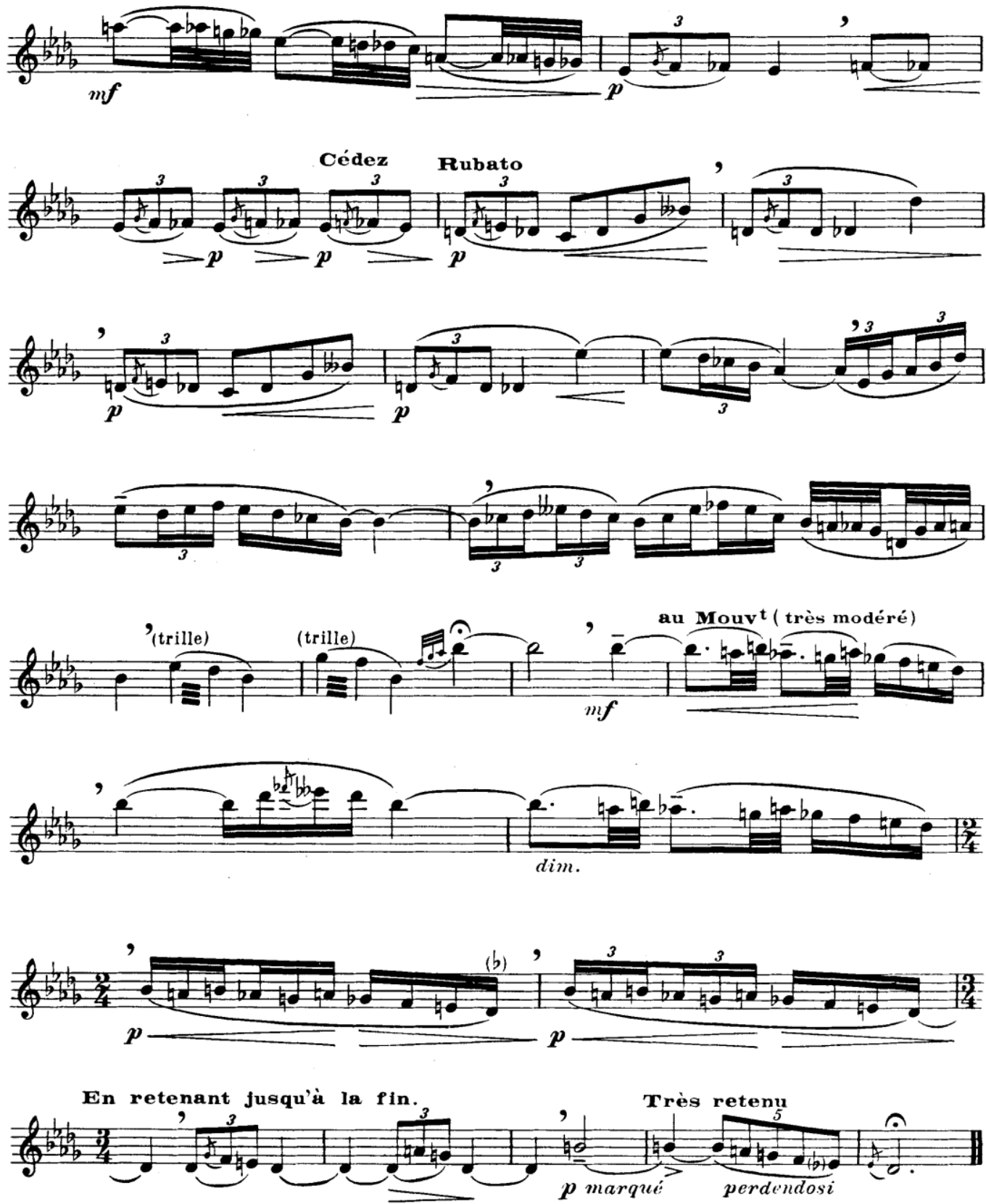

Ch. Douin grav.

Figura 1: edição de J. Jobert

Fonte: https://imslp.org 
Oreade: Mais voici que Pan recommence de sa flutte jouer

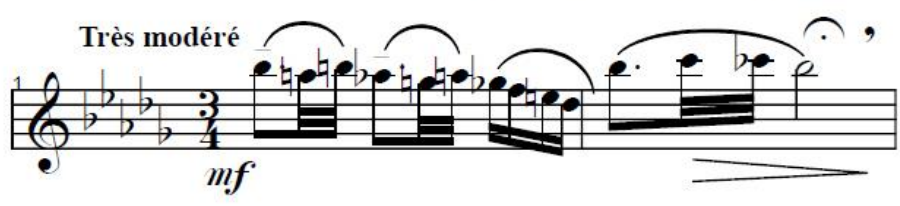

Oh! comme, dans les champs solennels du silence, Mélodieusement elles s'épanouissent!

\section{Naiade:}

Prodige! Il semble que la Nuit ait dénone Sa ceinture et qu'en écartant ses voiles Elle ait laissé, pour se jouer;

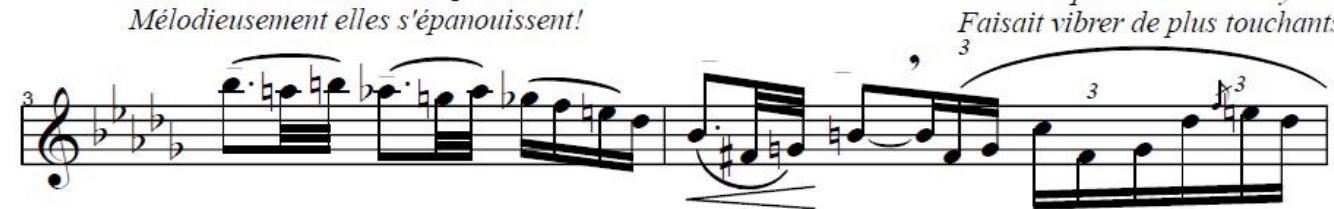

Et plus sublimes chants

Les cordes d'airain de sa lyre

Non, n'est-ce pas?

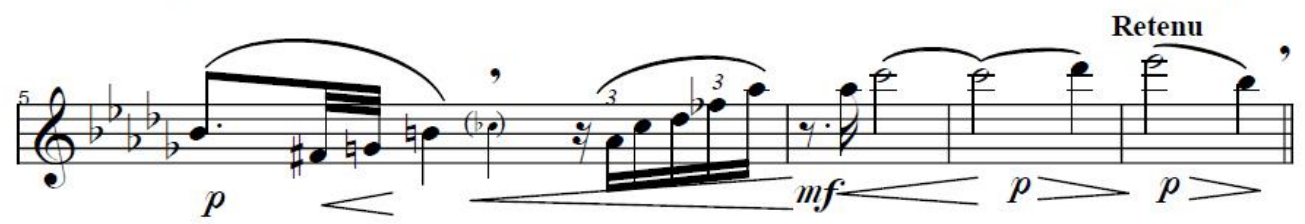

Oreade: Tais-toi, contiens ta joie, écoute

Naiade: Si tu savais quel étrange délire M'enlace, me pénètre toute!
Si tu savais... je ne puis pas te dire Ce que j'éprouve. La douceur

Un peu mouvementé mais très peu

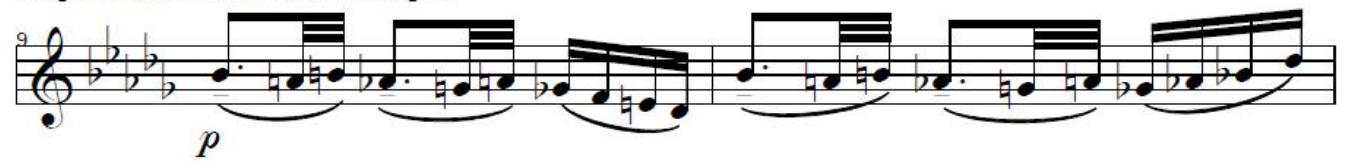

Voluptueuse éparse en cette muit m'affole... Danser, oui je voudrais, comme tes soeurs,

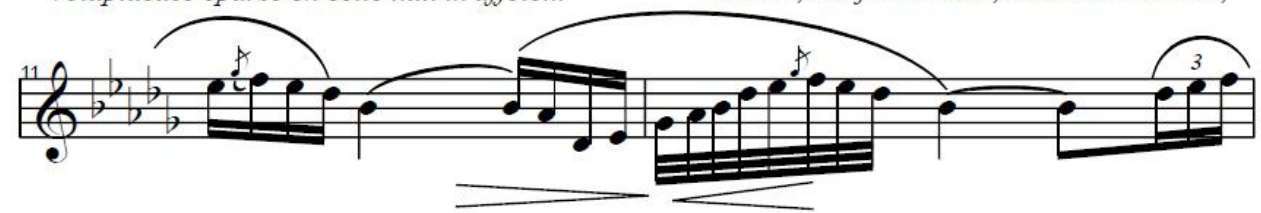

Danser.. frapper de mes pieds mus le

Avec d'harmonieuses poses, Eperdûment livrer mon corps

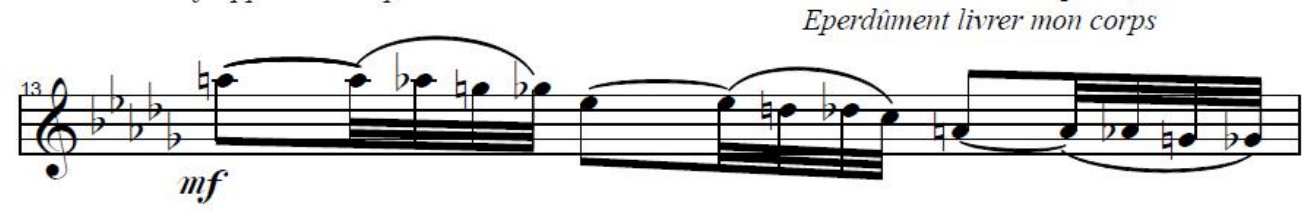

En cadence et, comme elles, sans effort,

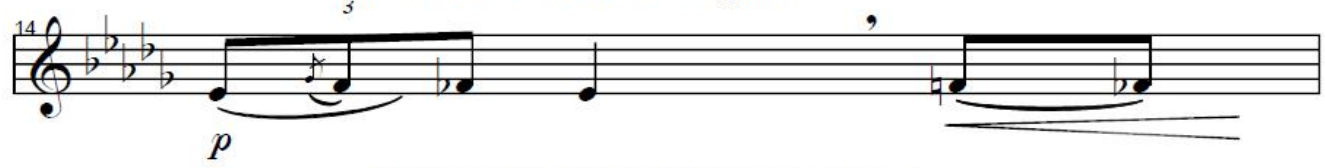

A la force ondovante et rvthmique des choses! 

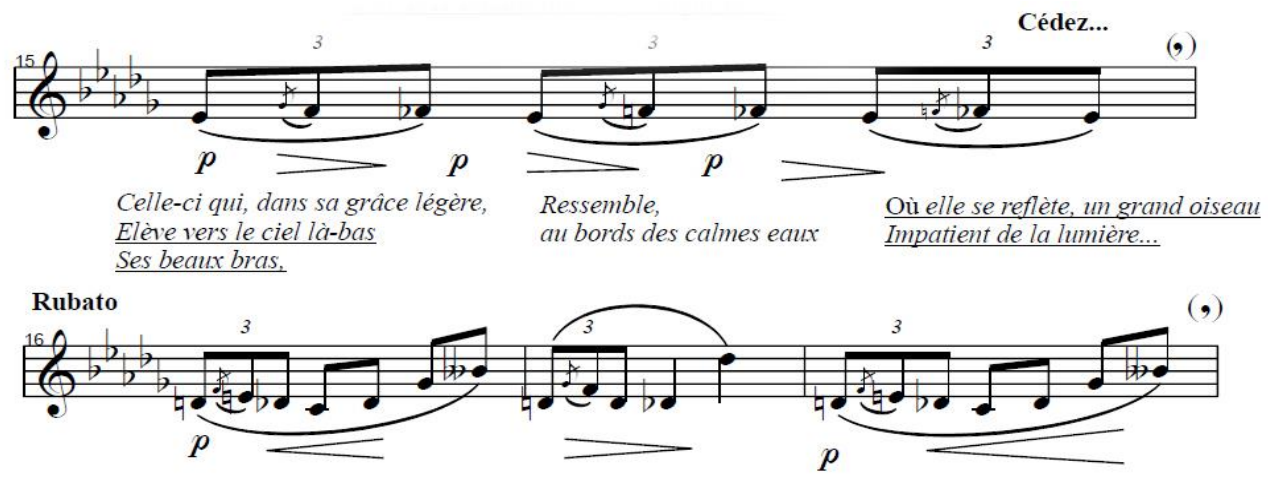

Et celle-là que des feuilles couromnent

Et qui, si complaisamment, donne

Aux lèvres de la lune à baiser ses seins blancs
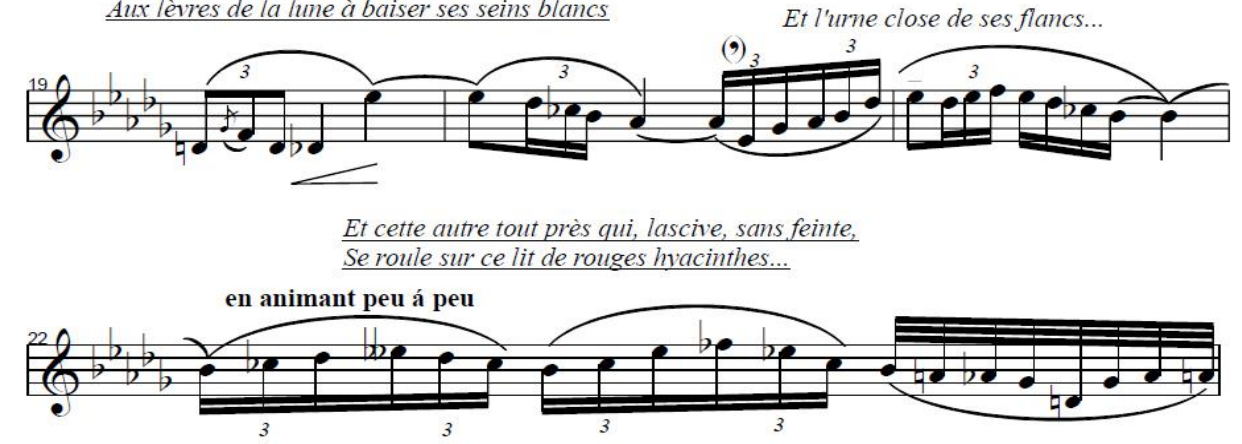

Et cette autre dont on ne voit plus que les veux Enticeler; telles deux taches

Par la chair d'elles toutes coule un feu divin

De soleil, dans la frondaison de ses cheveux

Qui l'enveloppent et la cachent...

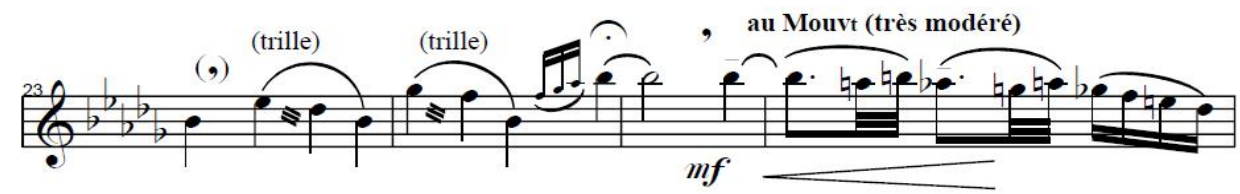

Et de l'amour de Pan toutes sont embrasées Et moi, la même ardeur s'insimue en mes veines,

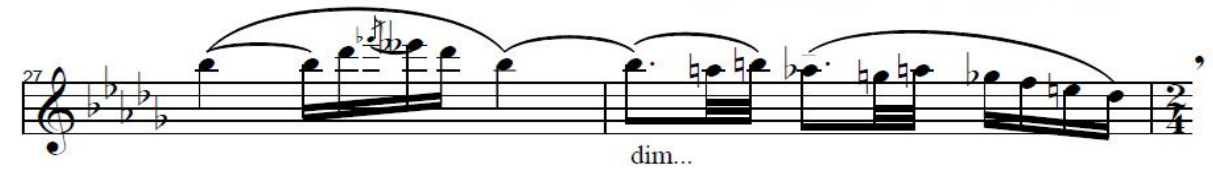

O, Pan, les sons de ta syrinx, ainsi qu'un vin

Trop odorant et trop doux, m'ont grisée'

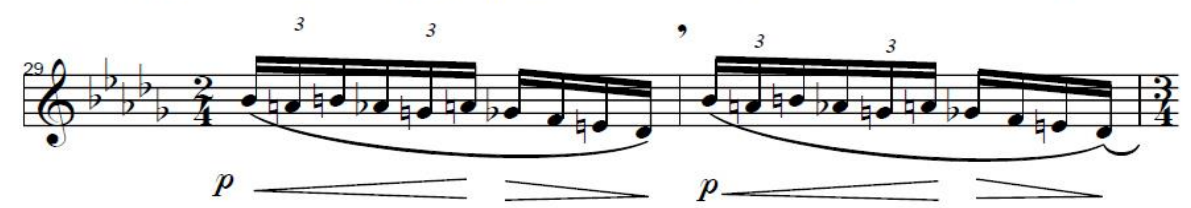

O Pan, je n'ai plus peur de toi, je t'appartiens!

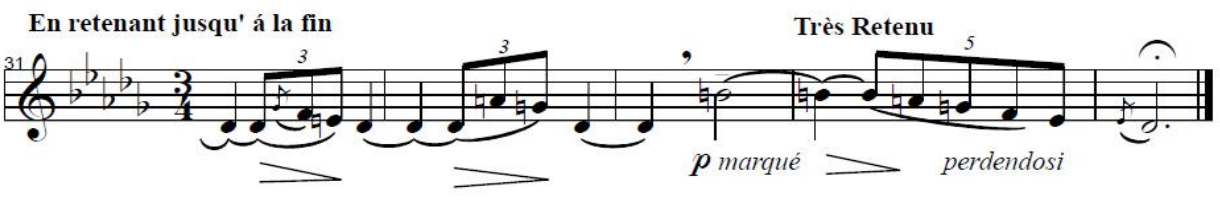

Figura 2: transcrição do manuscrito de Bruxelas

Fonte: Ewell, 2004, p. $84-86$ 
Comparação entre a edição de J. Jobert e o manuscrito de Bruxelas: as marcações que existem apenas na edição de J. Jobert estão sublinhadas de vermelho e as marcações que existem apenas no manuscrito de Bruxelas, estão sublinhadas em azul.
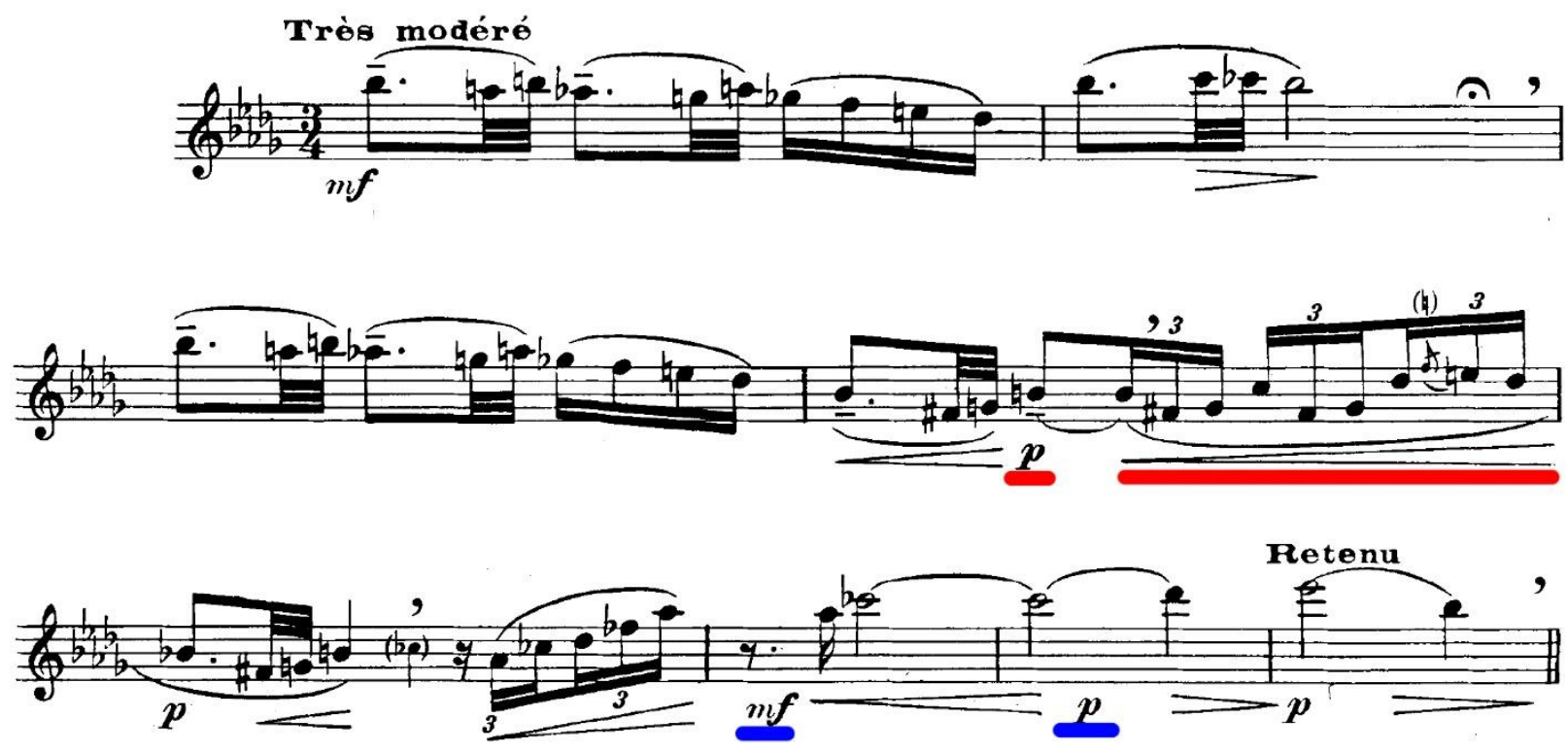

Un peu mouvementé ( mais très peu)
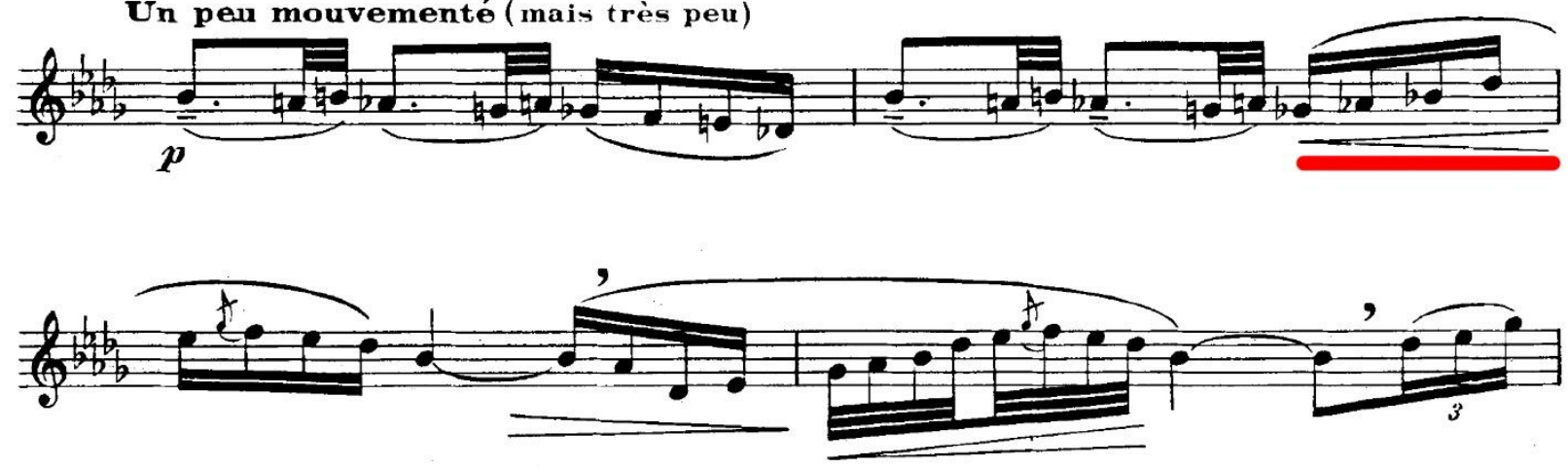

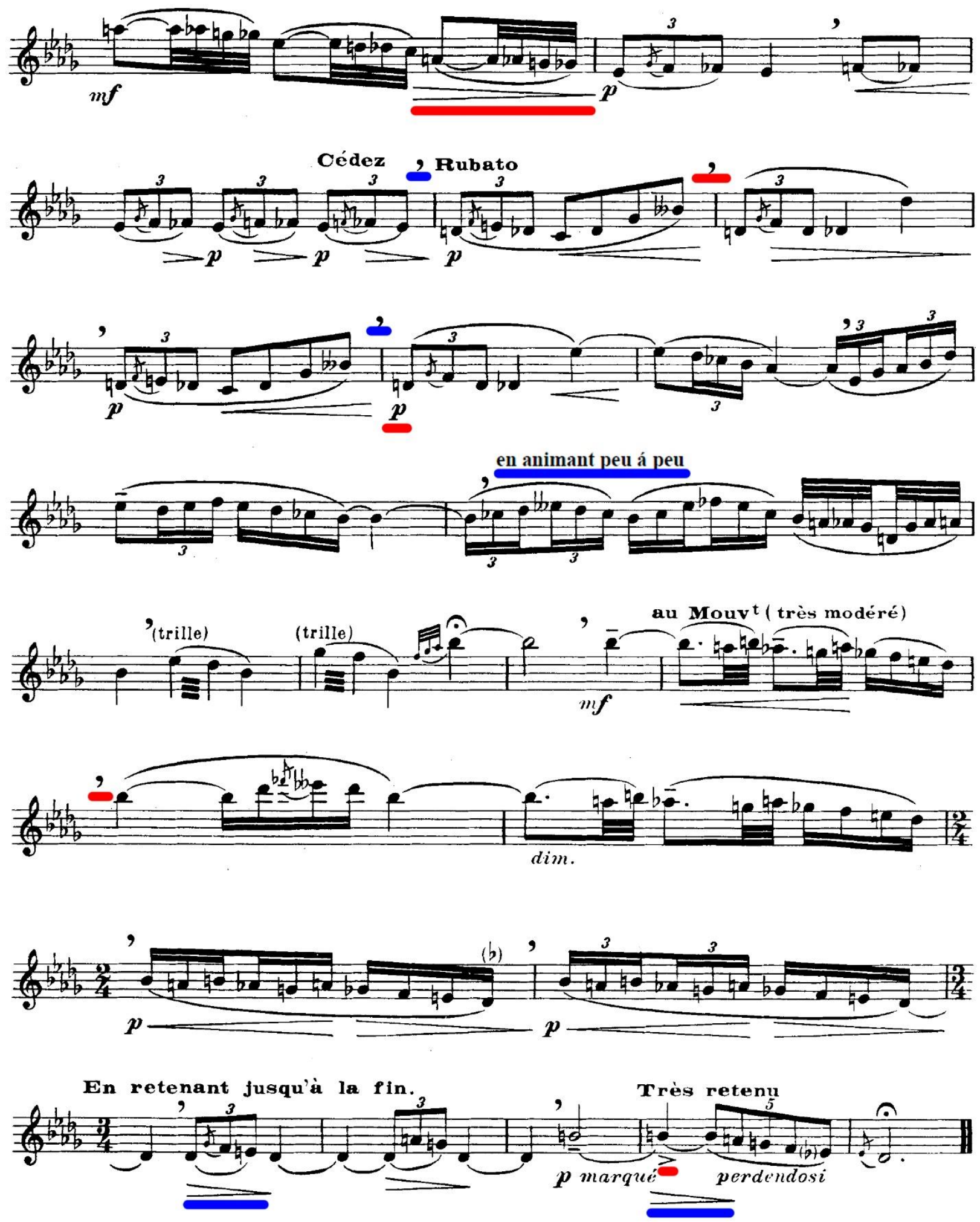

Figura 3: comparação entre a edição de J.Jobert e o manuscrito de Bruxelas 
A indicação Act III, scéne premiére causou alguma discórdia. Gabriel Mourey, em seu artigo "Memórias de Claude Debussy" diz ter requisitado à Debussy "a última melodia que Pan tocaria antes de sua morte" (MOUREY apud EWELL 2004, p. 2), e por isso Syrinx havia sido vista por muito tempo como uma composição para a cena da morte de Pan; a primeira cena, entretanto, trata da conversa de duas ninfas, uma Náiade e uma Oréade, respectivamente ninfa dos rios e ninfa das montanhas.

No início a Oréade pergunta se a Náiade nunca viu Pan, e ela responde ter medo dele; a Oréade diz então que uma vez que ela escutasse o som de sua música, ela não teria mais o que temer. A Náiade cita Syrinx e Echo como exemplos da crueldade de Pan. Echo era também uma ninfa, e falava muito. Uma versão de sua história diz que a deusa Juno a castigou fazendo com que ela só pudesse repetir o que as outras pessoas falassem, e quando o belo Narciso recusou o seu amor, desiludida, nada restou de seu corpo além da voz. Outra versão diz que ela rejeitou Pan, e este ordenou a seus seguidores que a matassem e espalhassem seu corpo por toda a terra. Mesmo morta, nas duas versões, ela continuou repetindo o que as pessoas falavam. A Oréade diz a ela que tem inveja das duas, principalmente da Syrinx, que vive até hoje através da respiração de Pan.

A Oréade narra então a história de Syrinx baseada nas Metamorfoses de Ovídio, e a última frase de sua fala é a primeira "deixa" escrita no manuscrito de Bruxelas (mais voici que Pan de sa flûte recommence a jouer; mas eis que Pan recomeçou a tocar sua flauta, tradução nossa). Então Pan começa a tocar sua flauta de dentro de uma gruta, e a Náiade se rende ao seu som e ao próprio Pan, sem mais ter medo.

Raul Costa D'Ávila relata que essa obra era tocada "durante os momentos de resignação e cólera do deus Pan junto às ninfas, culminando em sua agonia e morte". (D'ÁVILA s/d, p. 2). Além disso, também afirma que "sua inspiração se deu através de uma estátua Dernier Soupier de Pan" (D’ÁVILA s/d, p. 1), O Último Suspiro de Pan, tradução nossa.

Entretanto, Laurel Atrid Ewell diz que sua colocação da primeira cena é mais plausível, pois o som da flauta de Pan é especificado na fala das personagens, enquanto na cena da morte de Pan, além de não haver nenhuma pausa para ele tocar sua flauta, não há nada falando sobre ela. Ewell ainda cita 
alguns teóricos como Hellmut Seraphin, que diz que sua colocação na primeira cena seria mais adequada, e Roy E. Ernst e Douglass Grenn, que acreditam que a sensualidade presente na obra seria inapropriada para uma cena de morte. (EWELL, 2004, p. 6)

Independentemente de sua colocação na peça, Syrinx é a primeira peça para flauta sem acompanhamento que se tem registro desde a Sonata Solo de C. P. E. Bach de 1763, e também a primeira peça solo escrita para o mecanismo moderno de Boehm. Foi Louis Fleury que a divulgou independentemente da peça teatral, e depois de editada, Syrinx ganhou lugar fundamental no repertório flautístico, passando a ser considerada peça para ser tocada em público, como repertório de palco, e não mais atrás da cortina.

Outro exemplo que pode ser citado de modificação da função inicial de uma obra é O Cravo Bem Temperado de J. S. Bach, que nasceu como obra puramente didática, e hoje é apresentada em salas de concerto.

Então, para interpretação de Syrinx, o que seria o ideal? Tocar com o vigor de um concerto solo, ou como música funcional e descritiva de relevância secundária como ela foi inicialmente concebida? Existem muitas hipóteses interpretativas com que se podem abordar dessa obra, pois, como disse Salzman:

\footnotetext{
É erro ignorar a importância de ideias não-musicais, poéticas, no desenvolvimento das ideias musicais de Debussy, assim como no desenvolvimento das formas do seu pensamento musical, mas é igualmente importante observar que a sua intenção expressiva e poética pode ser compreendida também em termos estritamente musicais. (SALZMAN 1967, p. 30).
}

E para Raul Costa d'Ávila "a poesia dessa inigualável peça não é literária nem narrativa, mas está na criatividade musical de cada intérprete." (D’ÁVILA s/d, p. 2). 


\section{Capítulo IV - Análise Para Intérpretes}

Abordando o ramo das análises para performance e a fim de decodificar algumas intenções de Debussy, e de demonstrar as muitas possibilidades timbrísticas e interpretativas que essa peça pode proporcionar, será feita a seguir uma breve análise da partitura de Syrinx, tendo como base a edição de J. Jobert e fazendo algumas alusões ao manuscrito de Bruxelas. Além do estudo da partitura, essa análise tem em vista uma atenção especial às funções contextuais e aos meios de projetá-las, que é o que Rink chama de "análise para intérprete" (RINK 2007, p. 27), pois, apesar de a maior pista que temos das intenções do compositor ser a partitura, esta, por mais completa e sofisticada que possa ser, não consegue representar a totalidade dos elementos que existem numa performance (RINK, 2012). E, para essa peça, tocar o ritmo, as ligaduras e respirações corretas não é o suficiente para mostrar toda a beleza escondida entre as notas escritas por Debussy.

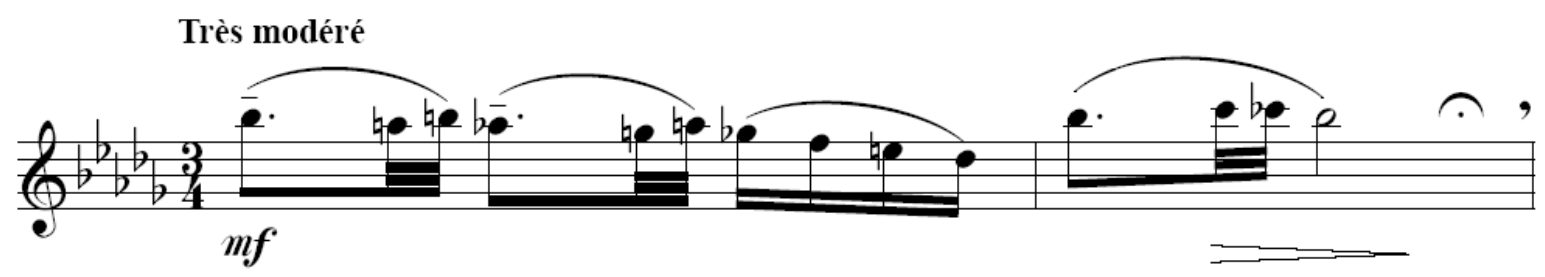

Figura $4^{1}$ : compassos 1 e 2

A música se inicia com uma frase descendente ornamentada por fusas, que gira basicamente em torno do Si bemol, terminando com um decrescendo (Tema A). Por ser descendente e cromático, o Tema A parece quase se desfazer. Algo que se desfaz geralmente perde força, sugerindo um alargamento do tempo; e a fermata presente após o Si bemol oferece o suporte necessário para que o intérprete faça um pequeno ritardando que marcará o final do tema.

\footnotetext{
1 Todas as figuras presentes nas análises têm como fonte o site https:imslp.org
} 


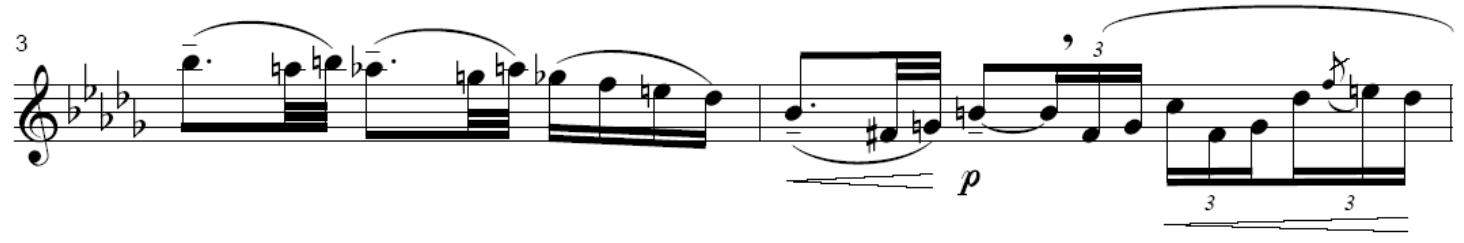

Figura 5: compassos 3 e 4

Após a marca de respiração, que segundo Raul Costa D'Ávila está "muitíssimo bem colocada, funcionando como suspiro e dando alívio ao suspense criado pelo Si bemol" (D'ÁVILA s/d, p. 4), segue o Tema A novamente, com uma variação no final. Nesse ponto não existe marcação de dinâmica, cabendo ao intérprete julgar o que deve ser feito com o som e timbre da flauta nesse momento. A flautista Barbara Kahkert sugere que, no início dessa segunda frase, mantenha-se a dinâmica pianíssimo, proveniente do decrescendo anterior.

$\mathrm{O} \mathrm{Si}$ bequadro que aparece em seguida pode ser considerado uma negação ao centro do tema que é o Si bemol. Apesar de haver um crescendo, o Si bequadro é marcado com a dinâmica piano. Talvez com a finalidade de evidenciar essa nova tensão, muitos intérpretes não correspondem a essa dinâmica. Esse antagonismo de crescendo seguido de piano aparece muitas vezes na peça e é característica de Debussy, podendo, portanto, ser enfatizado na execução. Se a opção do flautista for seguir a opinião de Barbara Kahlert, iniciando a frase em pianíssimo, deve-se nesse ponto então crescer até a dinâmica piano.

Acontece, então, uma intensificação rítmica, evidenciada pelas tercinas de semicolcheia. A apojatura que aparece pode ser bem enfatizada como efeito expressivo, demonstrando uma suposta volta à calmaria do Si bemol, que logo é desfeita pelo reaparecimento do Si bequadro.

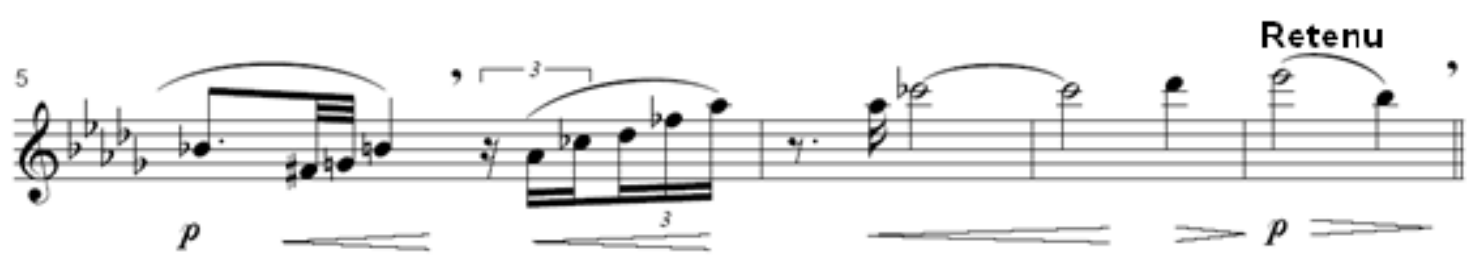

Figura 6: compassos 5 a 8 
A escala pentatônica ascendente quebra completamente o clima agitado quando seguida das mínimas (até agora a figura mais longa que apareceu). $O$ crescendo na nota Dó bemol é geralmente assinalado com um maior uso do vibrato, o Ré bemol, contudo, é marcado com um decrescendo para chegar no Mi bemol com dinâmica piano.

O Ré bemol é particularmente desafinado na flauta. Sua posição é muito aberta (é a mais aberta possível) e isso faz com que qualquer mudança de embocadura ou jato de ar traga um resultado nada desejado: uma desafinação. Cabe ao flautista dominar esse efeito, ou melhor dizendo, defeito do instrumento, o que é bastante difícil, principalmente num decrescendo.

Nesse ponto a primeira indicação de mudança de tempo aparece, o Retenu, e isso dá liberdade ao intérprete para alongar o tempo de Si bemol seguinte, decrescendo-o suavemente até que ele praticamente desapareça. A barra dupla e a marca de respiração indicam o final da primeira parte.

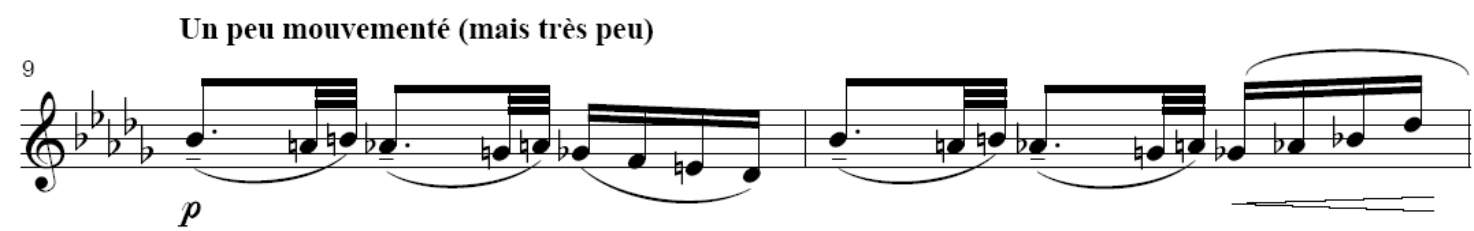

Figura 7: compassos 9 e 10

A segunda parte se inicia com a marcação un peu mouvementé. O Tema A se repete, desta vez oitava abaixo, com dinâmica piano, o que demonstra uma mudança de caráter. O grave da flauta, por ser mais rico em harmônicos, possui um som mais escuro, e a marcação de piano mostra que neste ponto, pode-se mudar o timbre do instrumento em busca de uma sonoridade mais misteriosa e enigmática. Devido a este fato, na repetição do Tema A na primeira parte, onde não há marcação de dinâmica, o intérprete não precisa criar um clima muito diferente do começo da peça, pois esse clima é esperado em seguida, na marcação un peu mouvementé. 


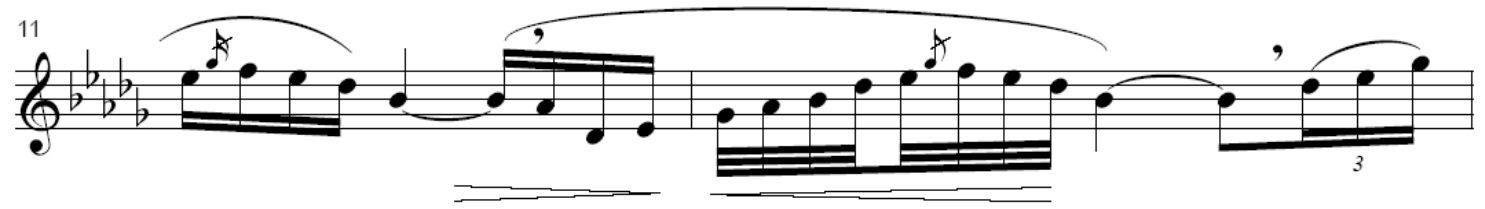

Figura 8: compassos 11 e 12

Após a repetição do Tema $\mathrm{A}$ na segunda parte, a linha da flauta desenha movimentos ascendentes com dinâmica crescente e descendentes com dinâmica decrescente, o que, de acordo com Mimi Stillman, "está de encontro com a prática da Art Nouveau de conectar linhas descendentes com um declive emocional e uma diminuição de energia" e vice-versa. (STILLMAN 2007, p. 43).

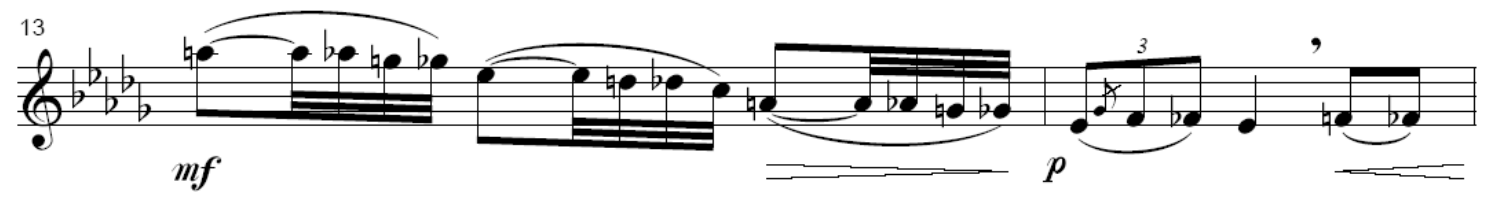

Figura 9: compassos 13 e 14

O Lá bequadro marcado com um mezzoforte é o ápice da segunda parte. As fusas em cascata e a dinâmica decrescente transformam o clima tenso do trítono Lá - Mi bemol em um novo tema de ritmo mais calmo, apresentado em tercinas de colcheia repletas de apojaturas (que já haviam sido usadas antes, mas aqui aparecem com mais força) com muitas variações de dinâmica.

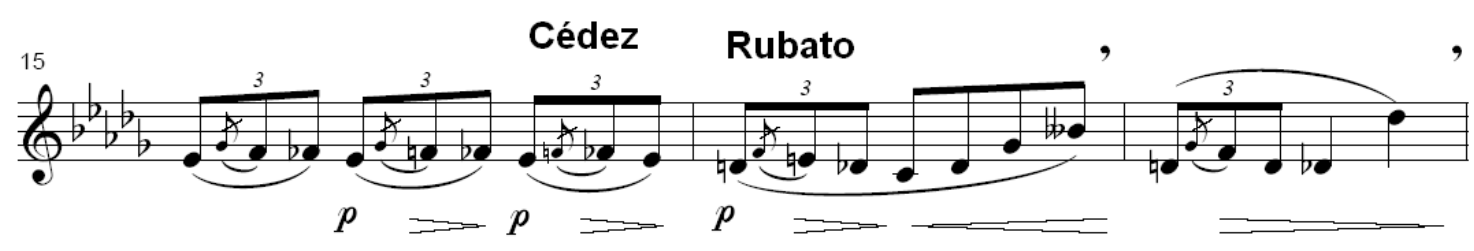

Figura 10: compassos 15 a 17

Há uma sequência de decrescendos seguidos de piano nessa parte, levando à duas interpretações possíveis: ou deve-se tocar em mezzopiano as notas entre a indicação de decrescendo e a marcação de piano, ressaltando assim as apojaturas; ou deve decrescer de piano para pianíssimo, e voltar à dinâmica piano onde indicado, ressaltando assim as primeiras notas das tercinas. A primeira opção é mais comum entre os intérpretes. 
Outra indicação de tempo aparece: o cedez, seguido do rubato. Nesse ponto estão marcados vários crescendos e decrescendos. O decrescendo na oitava ascendente de Ré bemol leva muitos intérpretes a usar um recurso puramente flautístico para deixar o timbre mais escuro e piano: o Ré bemol 2 não é feito com a posição real, e sim com um harmônico da primeira oitava, "pois esta forma timbricamente resultará numa sonoridade mais coerente com o todo do contexto musical e também ficará muito mais fácil para o intérprete" (D’ÁVILA s/d, p. 7).

Os dois Rés bemóis são seguidos por uma marca de respiração. Considerando a marca de respiração que aparece no final do compasso antecedente, essa respiração seria desnecessária. Mas ela está marcada e isso pode ser considerado um recurso expressivo para mexer com o tempo, algo como um rallentando. $O$ uso do rallentando nesse ponto também iria de encontro ao que Raul Costa D'Ávila diz a respeito desse ponto: "É como se momentaneamente tudo estivesse resolvido, já que a sensação de diluição provocada pelo Ré bemol, que sugere ser a tônica, causa a impressão do repouso." (D'ÁVILA s/d, p. 5).

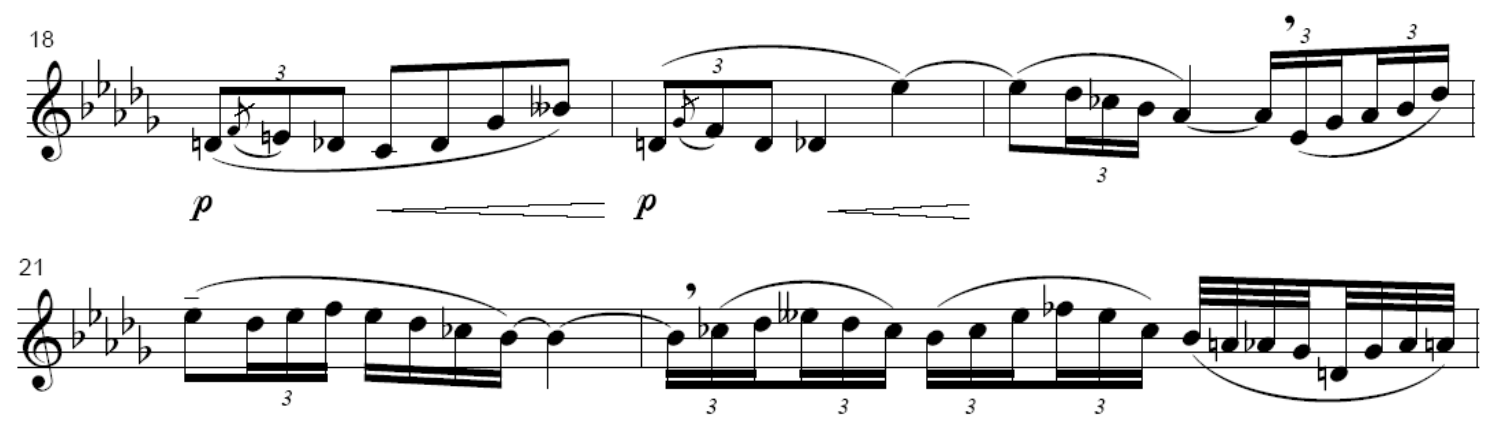

Figura 11: compassos 18 a 23

A marcação crescendo seguida de piano acontece novamente na frase em seguida, que é quase uma repetição da frase antecedente. O piano é então como uma inovação, pois anteriormente o Ré bequadro apareceu como ápice, entre um crescendo e um decrescendo, e agora aparece piano para dar espaço ao crescendo no Mi bemol. Depois disso se inicia uma série de diminuições rítmicas, que, apesar de demonstrarem claramente uma maior tensão, não são realçadas com nenhuma marcação de dinâmica nem de mudança de tempo na 
edição de J. Jobert. Apenas a volta do tema é marcada com a dinâmica mezzoforte e a indicação au mouvt. O manuscrito de Bruxelas, por outro lado, traz nesse ponto uma indicação de En animant peu à peu, no compasso 22.

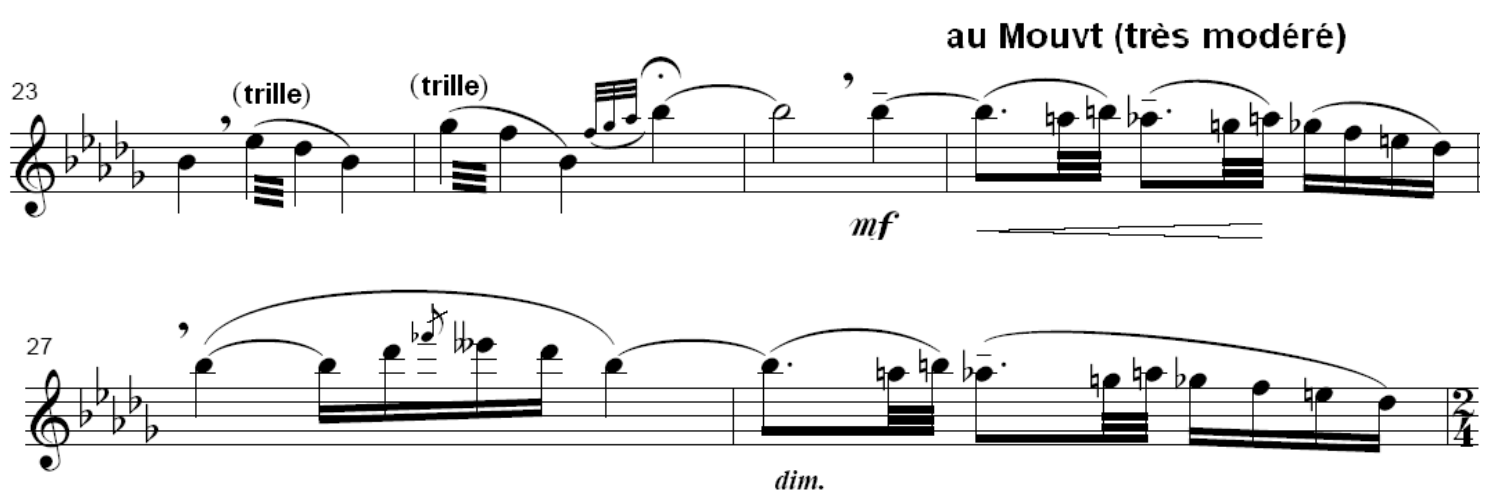

Figura 12: compassos 23 a 28

O trillo sugere o auge do agitamento rítmico, seguido da apojatura de três notas para o Si bemol, que dá espaço a um crescendo, devido à fermata. Depois da respiração, o outro $\mathrm{Si}$ bemol deve relembrar o início da peça, pois está marcado com a indicação au Mouvt (très modéré), mostrando o início da terceira parte. Mas o som deve se tornar mais forte e vibrante logo após, pois o crescendo marcado, a outra marca de respiração e o cume da nota mais aguda de toda peça, precedida ainda por uma apojatura, nos provam que esse é o ponto de maior expressão agônica em Syrinx.
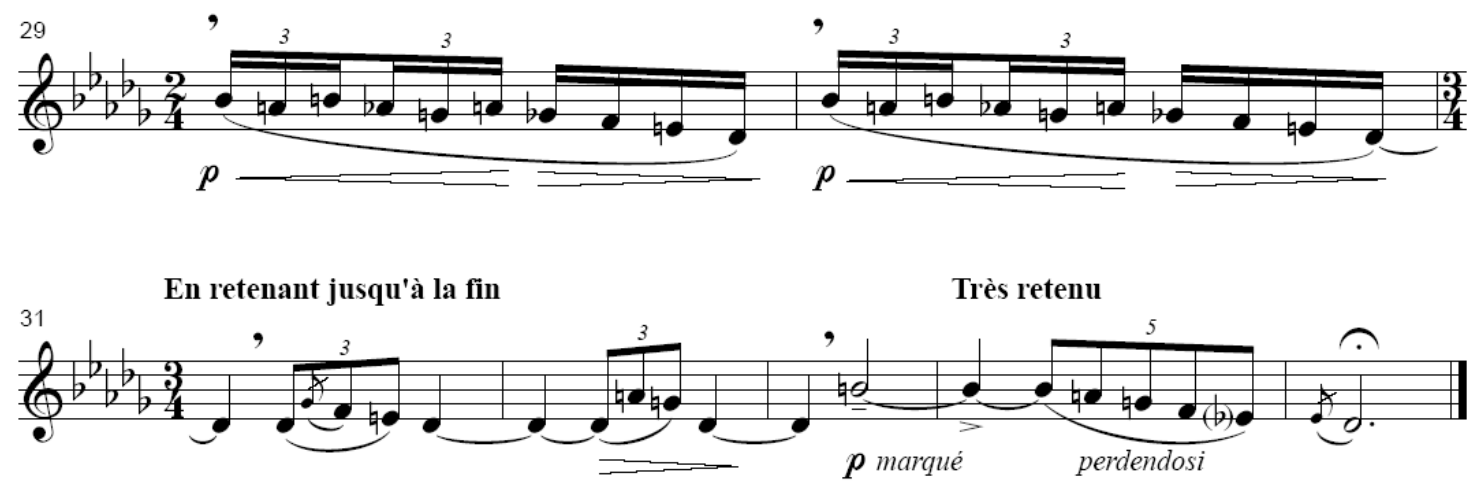

Figura 13: compassos 29 a 34

Depois do diminuendo do compasso 28, o tema aparece variado, diluído, com indicação de piano e um crescendo e decrescendo, que são muitas vezes 
esquecidos pelos intérpretes. Voltando a dinâmica piano na marcação en retenant jusqu'à la fin, o flautista pode, então, criar um timbre escuro, nebuloso e sem muito vibrato.

O Si bequadro que aparece depois da respiração tem um acento e a indicação marqué, e no próximo Si bequadro, que está ligado a esse, existe um acento. Isso leva muitos intérpretes a fazer um crescendo nessa nota, que não está indicado. Outra interpretação comum é um acento feito com o ar nesse ponto.

No manuscrito de Bruxelas, porém, em vez de um acento no Si bequadro, está marcado um diminuendo, o que iria mais de encontro com o caráter do final da peça, visto que ele está marcado com várias indicações de diminuição rítmica (très retenu e perdendosi). Em seu artigo, Laurel Astrid Ewell cita a opinião de Jean-Pierre Rampal sobre o acento: “Jean-Pierre Rampal descreve o efeito como a 'exalação final' de Pan." Ela também diz que de acordo com o manuscrito, fazer um acento nessa nota seria um erro e cita a opinião de Trevor Wye que implora aos flautistas para "pararem de tocar esse soluço bobo antes do final dessa peça maravilhosa”. (EWELL 2004, p. 55)

O Si ligado talvez foi acentuado na edição de J. Jobert para demonstrar que ele não deve decrescer tão rapidamente, e sim ser todo marcado (como pedido pela indicação marqué). Sendo assim, ele negaria os tantos Si bemol que apareceram no início da peça e foram salientados como centro tonal. Ele está marcado com as indicações très retenu, e perdendosi, que afirmam (e reafirmam) que o final da peça deve ser feito de tal maneira que o som vá se apagando brandamente até chegar ao silêncio.

Syrinx se mostra então como uma peça de grande liberdade interpretativa. Mimi Stillman diz que "Debussy frequentemente escreveu linhas em arabesco para a flauta, por exemplo, em Syrinx, percursos sinuosos dão a peça um caráter de espontaneidade" (STILLMAN 2007, p. 42). Essa "espontaneidade" dá liberdade ao intérprete para executar o ritmo quase como um elástico: onde há mais notas sente-se um acelerando e vice-versa, fazendo assim com que tudo pareça uma grande improvisação de tempo impreciso e muito uso de rubatos. Ao intérprete, por não haver muitas marcações, também cabe um vasto uso de variações de dinâmica e timbre. 
Em relação ao controle de dinâmica e nuances, entra uma dificuldade flautística que pode vir a atrapalhar um pouco a execução dessa peça: apesar de o sistema atual do instrumento (sistema Boehm) ter ajudado bastante, a flauta ainda traz alguns problemas de afinação. Geralmente o que acontece é que quando se joga mais ar no instrumento, num crescendo, ou num forte, por exemplo, a afinação tende a subir, e o contrário também é válido: num decrescendo ou num piano, a afinação tende a cair. Numa peça solo como essa, a afinação fica bem visível e transparente, deixando entrever quaisquer problemas de afinação que possam aparecer. O que se sente algumas vezes é que, mesmo na interpretação de bons flautistas, há uma preocupação tão grande tocar sempre tudo forte, que na hora de executar com precisão uma passagem delicada, em piano, ou às vezes um decrescendo, esse problema de afinação do instrumento não consegue ser contido.

Outra especificidade do instrumento é que ele não tem naturalmente um som muito potente e aberto nos graves. Mas, nem sempre a flauta necessita de um som exageradamente forte, e Syrinx é um ótimo exemplo disso; Raul Costa D'Ávila inclusive diz para "não ultrapassar o limite de intensidade mezzoforte. Debussy explora, com todo requinte, a região que é natural da flauta". (D'ÁVILA s/d, p. 7). O que acontece é que alguns flautistas, talvez querendo mostrar que possuem um som potente nos graves, não respeitam a dinâmica que Debussy escreveu tão sabiamente.

Todos esses aspectos devem ser levados em consideração ao interpretarse Syrinx, que, segundo Raul Costa D'Ávila:

...exige certa maturidade por parte do flautista para ser bem executada. Esta maturidade se reflete no encontro da verdadeira poesia sonora, uma vez que esta poesia não se limita apenas ao ritmo e as notas, mas numa compreensão do todo que inclui: sonoridade expressiva; timbres variados; crescendos e decrescendos bem executados; sendo tudo isto aliado a um íntegro espírito de comunhão com a ideia de concepção da peça. (D’ÁVILA s/d, p. 7). 


\section{Capítulo V - Análise Harmônica}

Ainda no campo da análise para performance, será feita agora uma análise harmônica. Essa forma de análise está no que Rink chama de análise mais rigorosa. Para ele, essa forma de análise consiste na utilização de técnicas que tivessem suas terminologias e conceitos assimilados para uma melhor capacidade de articulação do intérprete, porém, não necessariamente seus resultados seriam diretamente aplicados à performance (RINK, 2007).

\footnotetext{
O problema de encontrar novas maneiras do discurso musical, de substituir os princípios clássicos de desenvolvimento e variações de tonalidade por novos conteúdos e nova forma expressiva, ocupou as melhores mentalidades musicais em torno de 1900 (SALZMAN 1967, p. 27).
}

Para ir ao encontro com o que buscavam os compositores dessa época, Debussy criou um estilo que foi contra a educação musical, fiel aos princípios clássicos, que recebeu no Conservatório de Paris, onde permaneceu por onze anos. "Debussy rejeitou aspectos musicais e formas que julgou rígidas em favor de uma música que enfatizava cores, texturas e contraponto." (STILLMAN 2007, p. 43).

A harmonia que Debussy utilizou em Syrinx funciona muito bem para flauta solo, pois estrutura-se em "mutações modais", isto é, em mudanças sucessivas de escalas vigentes na época. Tentando evitar as relações tonais hierárquicas que as escalas maior e menor estabelecem, as escalas que Debussy utiliza em Syrinx são escalas simétricas, pois, em sua música...

\footnotetext{
...os sons e os padrões de sons relacionam-se um ao outro através de critérios auditivos arbitrários e sensuais, em vez de se relacionarem através das antigas necessidades de movimento e de resolução governadas pela lógica linear, tonal. (SALZMAN 1967, p. 29).
}

Apesar do uso da escala de tons inteiros ser frequentemente apontado como única forma composicional de Debussy, uma análise harmônica de Syrinx comprova que "as relações de tons inteiros são usadas por Debussy em 
concomitância com ou parte de um grupo de utilizações harmônicas e melódicas muito mais complexo." (SALZMAN 1967, p. 30).

Identificando as escalas utilizadas e suas mutações, identificar-se-á também o movimento harmônico da peça. Esse movimento, em Debussy, determina o colorido tonal, abrangendo também a linha melódica. Uma análise harmônica de Syrinx, portanto, mostraria ao intérprete opções timbrísticas, e de colorido sonoro.

Para melhor compreensão dessa análise serão explicitadas previamente as escalas que utilizadas na confecção da teia harmônica dessa peça. 


\section{V.I - Escalas Utilizadas}

Uma escala muito usada por Debussy em Syrinx é a escala de tons inteiros. Como o próprio nome já diz essa escala não possui nenhum intervalo de semitom. Sendo assim, existem apenas duas variações possíveis (considerando os enarmônicos), e a soma dessas duas variações é o total cromático.

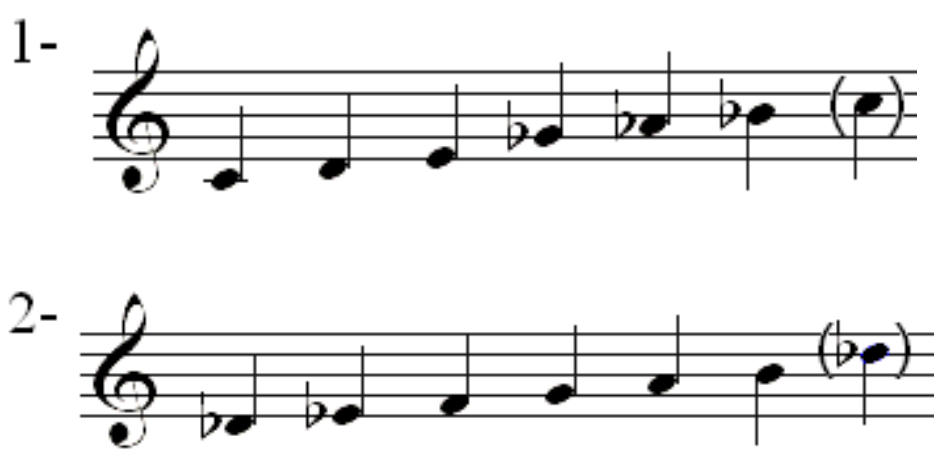

Figura 14: escalas de tons inteiros utilizadas

Outra escala que aparece na peça é a escala octatônica. Essa escala é formada pela sequência de tom e semitom, o que gera uma escala com o total de oito sons. Para ela, existem três variações possíveis (considerando também os enarmônicos).

$1-$

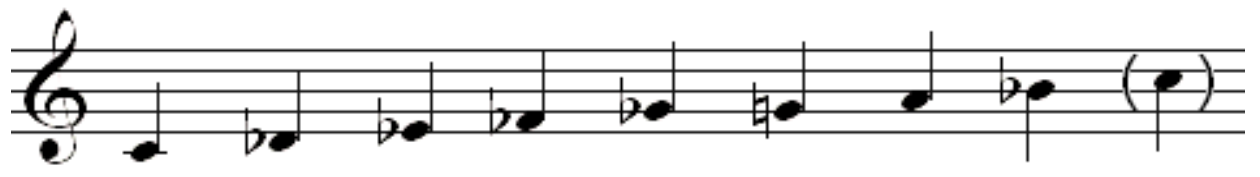

2-

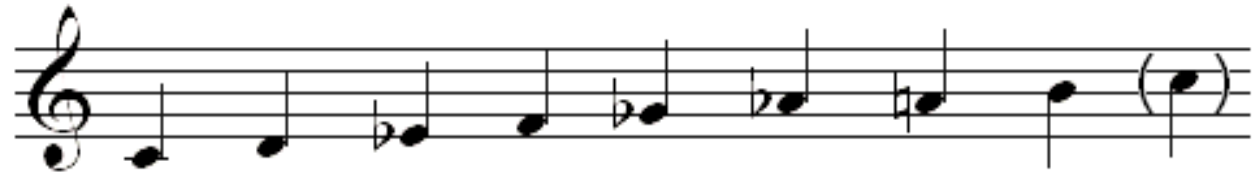

3-

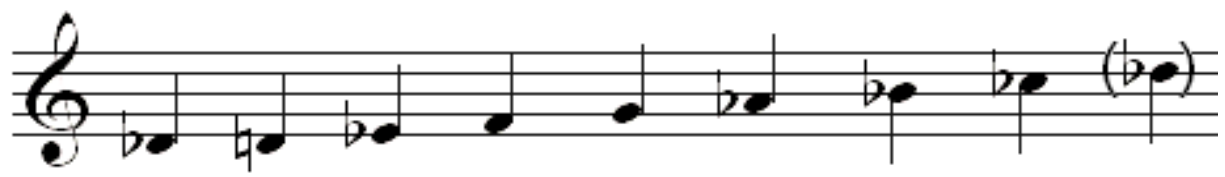

Figura 15: escalas octatônicas utilizadas 
A escala pentatônica também é usada por Debussy em Syrinx. Essa escala se forma pela sequência dos intervalos de tom / tom / tom + semitom / tom / tom + semitom e suas alternâncias, formando uma escala de apenas cinco sons. Para ela existem cinco variações e cada uma das cinco pode ser transposta para todos os 12 sons da escala cromática. Aqui serão mostradas as cinco variações possíveis, todas começando pela nota Dó.

$1-$

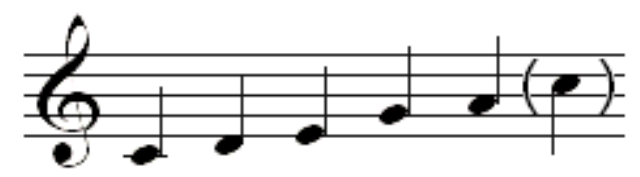

2-

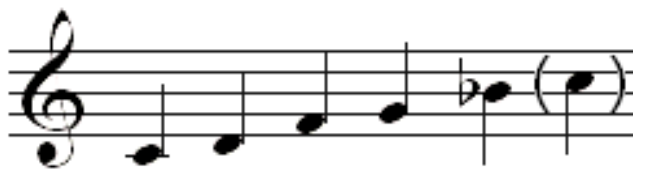

$3-$

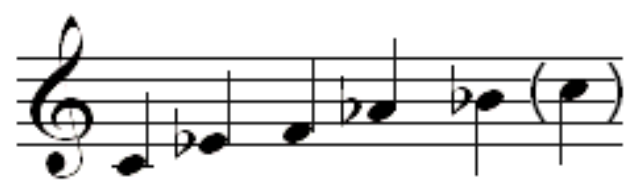

$4-$

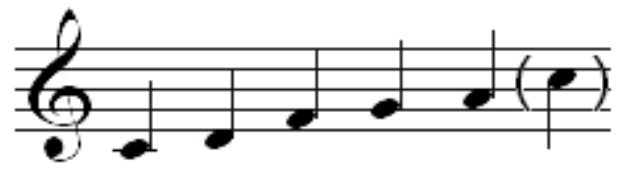

$5-$

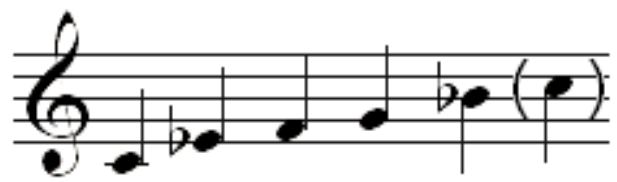

Figura 16: escalas pentatônicas utilizadas 


\section{V.II - A Análise Harmônica}

Apresentadas as escalas, a seguir será feita a análise harmônica da peça. Para melhor visualização na partitura, foram atribuídas cores diferentes para cada escala utilizada.

Na primeira pauta, Debussy alterna as duas variações possíveis da escala de tons inteiros, que serão chamadas de TI-1 e TI-2. Uma delas aparece nas notas mais longas, e a outra nas notas de ornamento. Apenas no final da frase uma nota da escala TI-1 aparece nas fusas, o Dó natural, que está deslocado (fator que pode dar ao intérprete a liberdade de fazer, nesse ponto, um rallentando para evidenciar esse deslocamento).

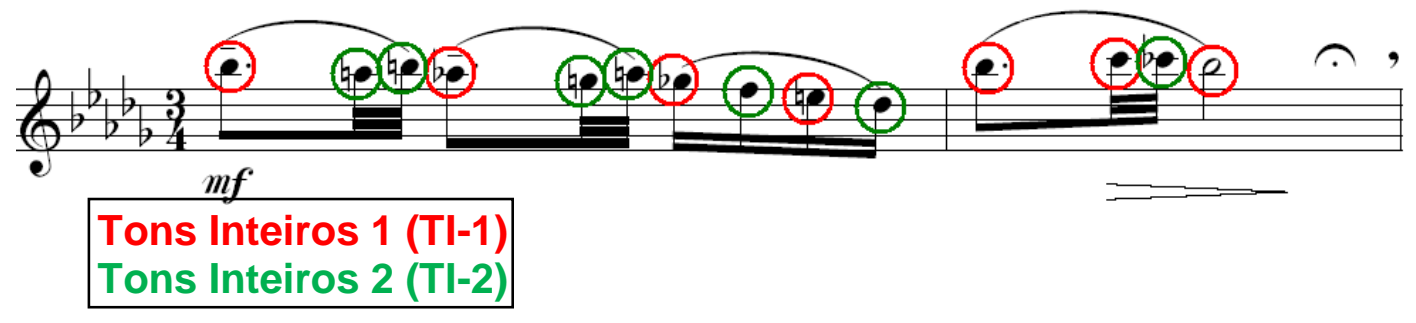

Figura 17: análise harmônica compassos 1 e 2

A escala TI-1 é nesse ponto mais importante que a escala TI-2. O Si bemol aparece com bastante força nessa frase, o que gera uma dúvida de que talvez o tom da peça fosse Si bemol menor, e não Ré bemol maior.

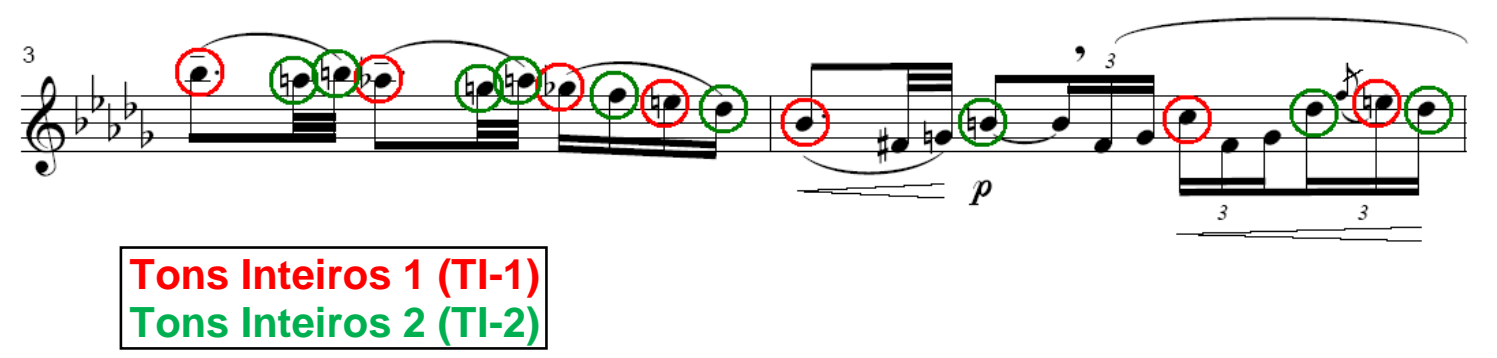

Figura 18: análise harmônica compassos 3 e 4

A segunda pauta traz as escalas Tl-1 e Tl-2 alternadas novamente, e na terceira pauta surgem duas escalas pentatônicas, chamadas de P-1 e P-2, de acordo com a ordem de seu aparecimento na obra. As duas pentatônicas não 
aparecem completas nesse ponto, faltando a nota Sol bemol em ambas as escalas. O Si bemol que finaliza a frase pertence à escala TI-1, mostrando uma volta ao teórico "tom" da obra.

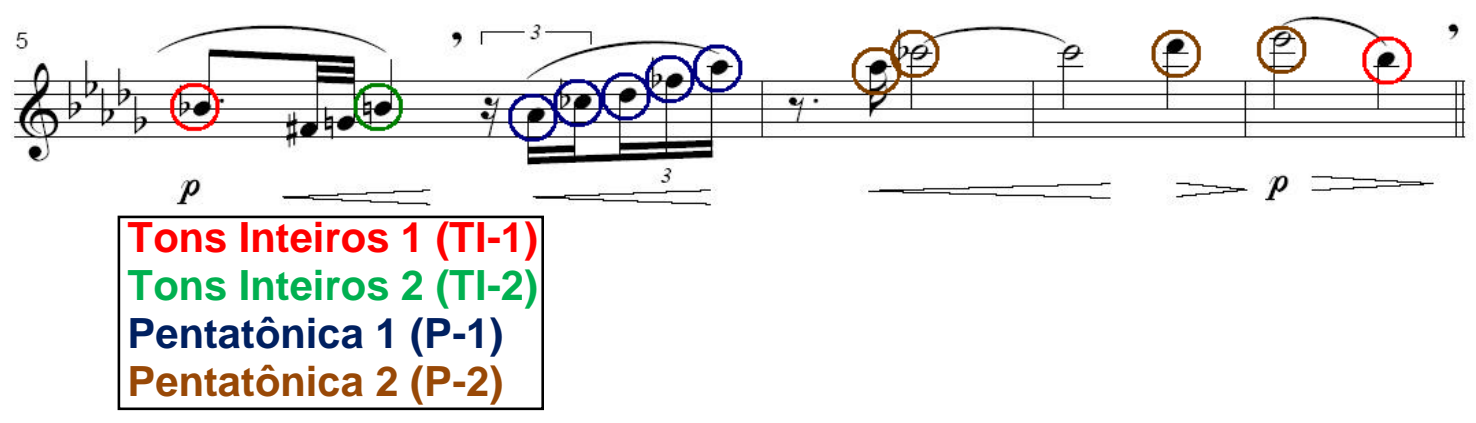

Figura 19: análise harmônica compassos 5 a 8

No final da quarta pauta, aparece uma terceira escala pentatônica, chamada de P-3, que se desenvolve plenamente na pauta seguinte.

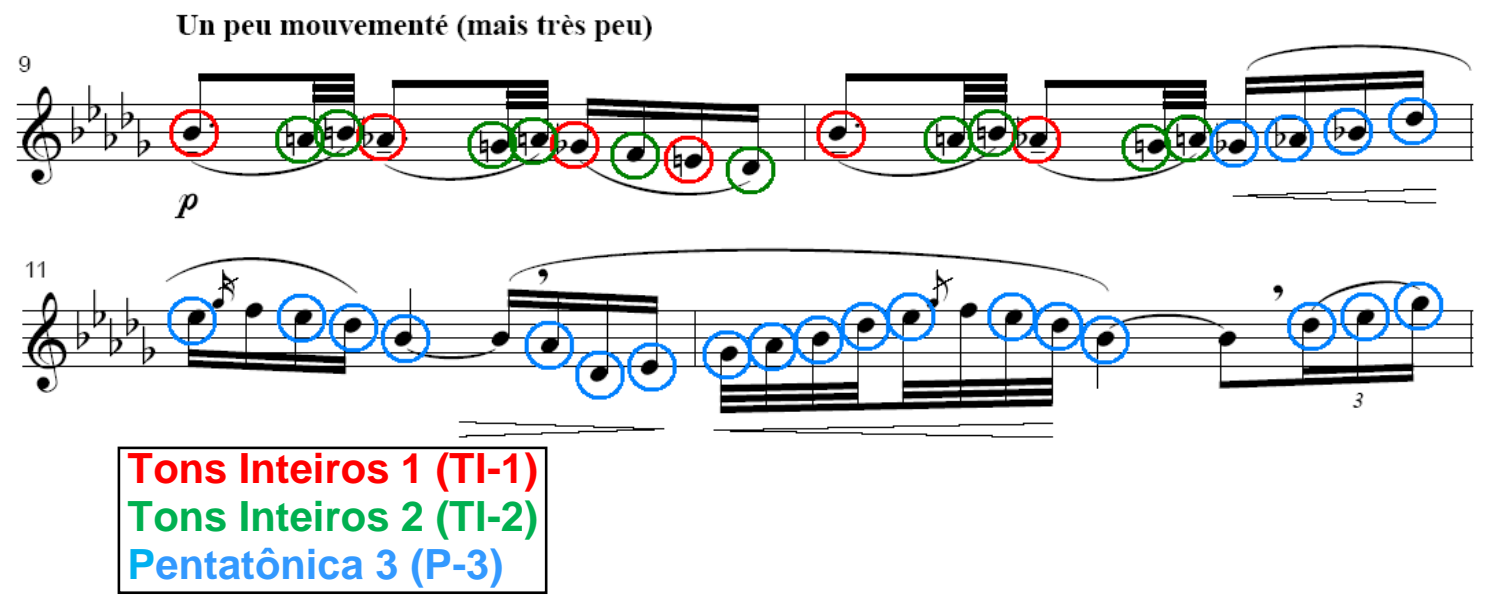

Figura 20: análise harmônica compassos 9 a 12

As escalas Tl-1 e TI-2 continuam intercalando-se, até que, no compasso 16, surge a primeira escala octatônica da peça $(0-1)$. Logo em seguida, nos compassos 17 e 19, aparecem as outras duas formas possíveis da escala octatônica (0-2 e 0-3, assim chamadas de acordo com a ordem que aparecem na peça e também nos exemplos anteriores à análise). 


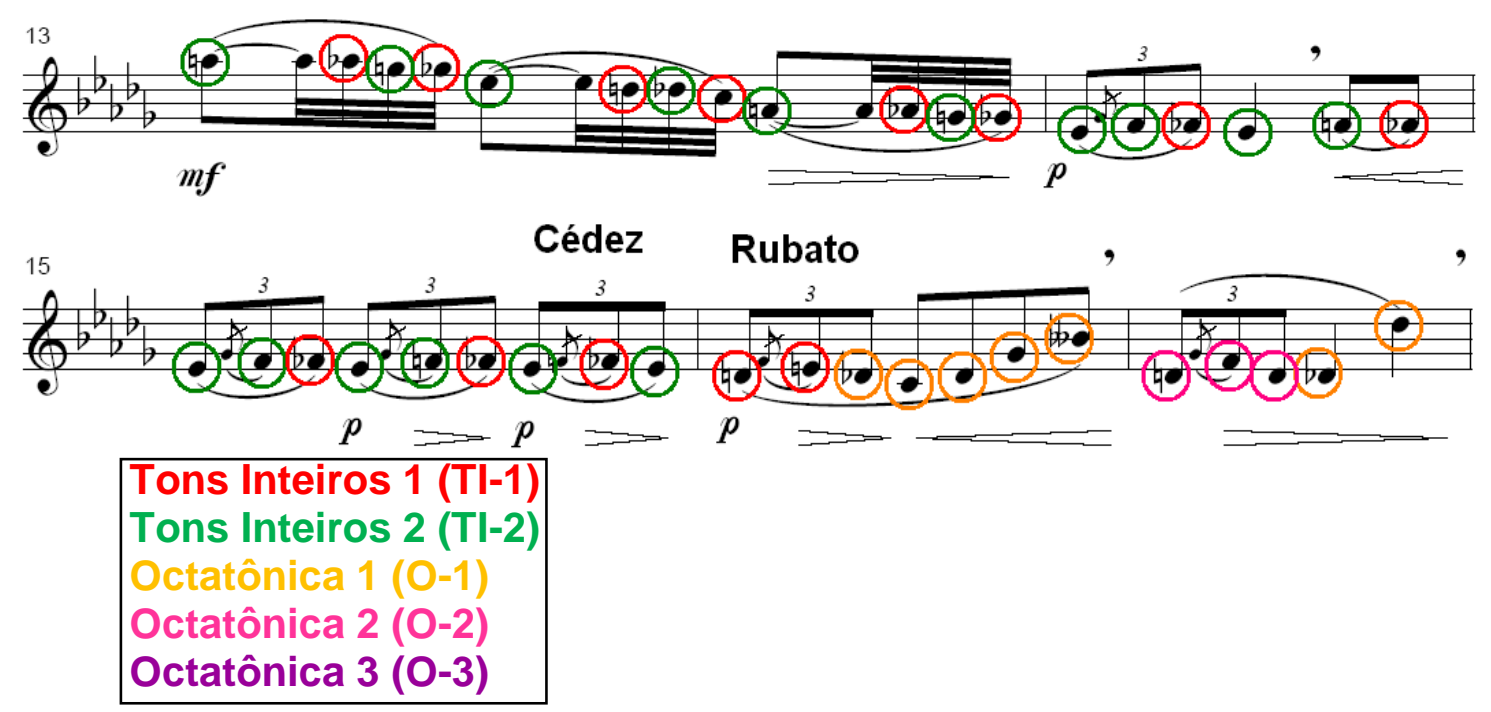

Figura 21: análise harmônica compassos 13 a 17

A passagem que se inicia no compasso 20 é de grande intensidade harmônica, pois utiliza as escalas P-3, TI-2, 0-3, O-2 e P-3 novamente. O compasso 26 volta ao tema inicial da obra, que se desenvolve até o compasso 30, sempre alternando as escalas TI-1 e TI-2.
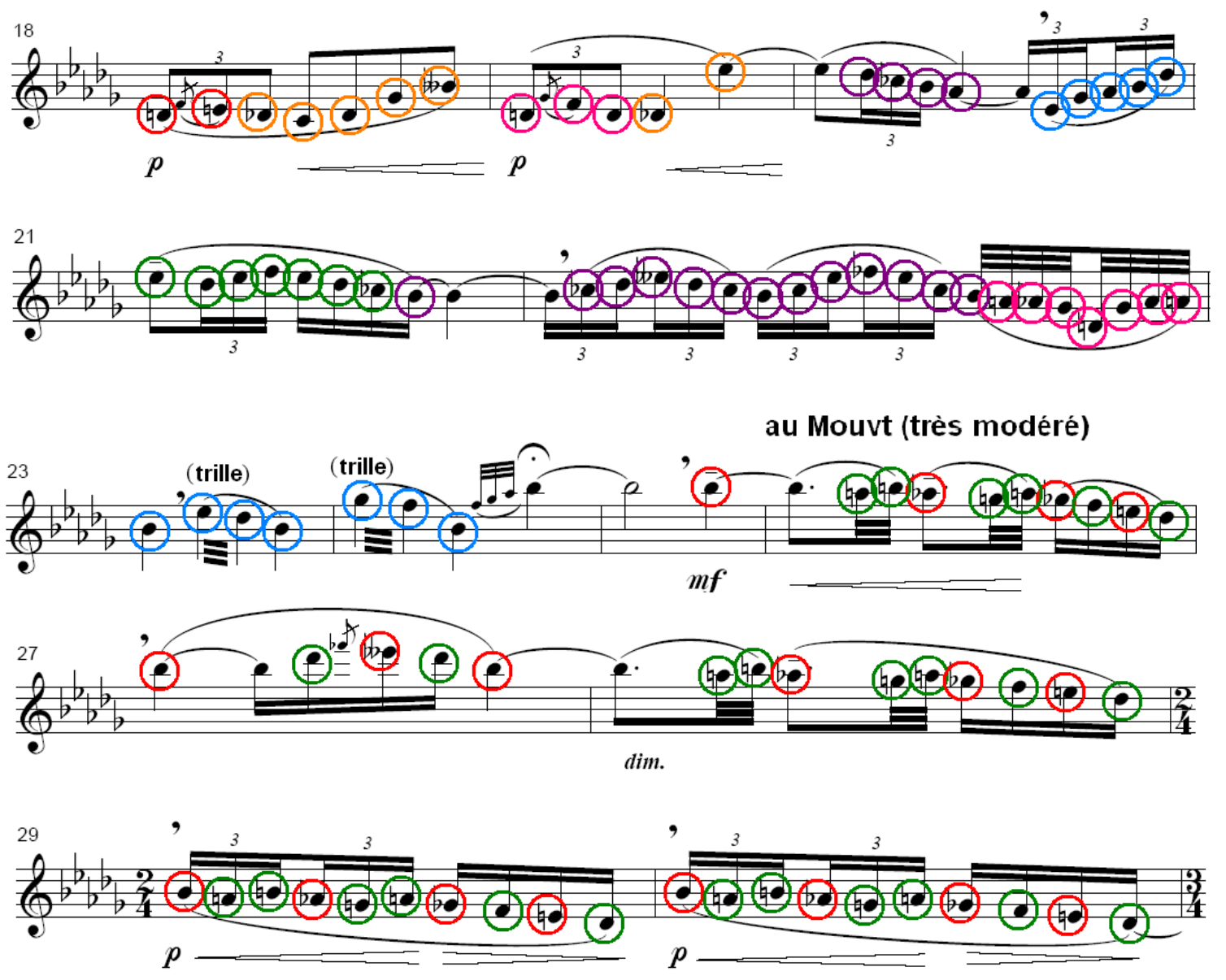

47 


\begin{tabular}{|l|}
\hline Tons Inteiros $1(\mathrm{Tl}-1)$ \\
Tons Inteiros $2(\mathrm{TI}-2)$ \\
Pentatônica $3(\mathrm{P}-3)$ \\
Octatônica $1(\mathrm{O}-1)$ \\
Octatônica $2(\mathrm{O}-2)$ \\
Octatônica $3(\mathrm{O}-3)$ \\
\hline
\end{tabular}

Figura 22: análise harmônica compassos 14 a 30

Na última pauta, a TI-2 ganha mais espaço que a TI-1, e no compasso 34, ela aparece em sua forma completa, dissolvendo a dúvida que o Si bemol tinha gerado em torno do tom da peça.

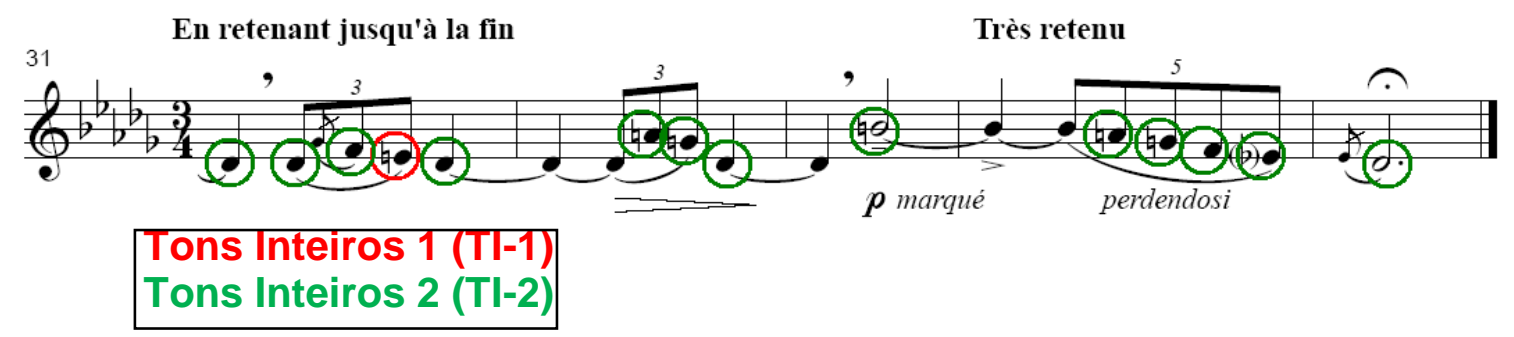

Figura 23: análise harmônica compassos 31 a 35 


\section{Capítulo VI - Análise Motívica}

A análise motívica, como o próprio nome diz, busca encontrar os motivos musicais que formam uma peça, e as relações que o compositor estabeleceu entre eles.

Para Nicholas Cook, analisar motivicamente uma obra musical significa

em primeiro lugar, cortá-la em unidades que possuem algum grau de significância dentro da peça, e, em segundo lugar, analisar o modo que essas unidades são distribuídas durante a peça, com a menção de descobrir os princípios que governam essa distribuição (COOK 1994, p. 151).

Uma análise motívica de Syrinx, portanto, visa mostrar para o intérprete um meio de comunicar os significados da música através dos motivos que possui. 


\section{VI.I - Apresentação dos Motivos}

Foram identificados em Syrinx três motivos principais, e todos eles aparecem na primeira pauta da partitura: o primeiro é uma nota longa, que não tem relações com notas ou motivos anteriores; o segundo são as fusas cromáticas; e o terceiro são as notas em escala descendente, terminando em ascensão. Os outros motivos que aparecem ao longo da peça são derivados desses três motivos principais e de suas variações.

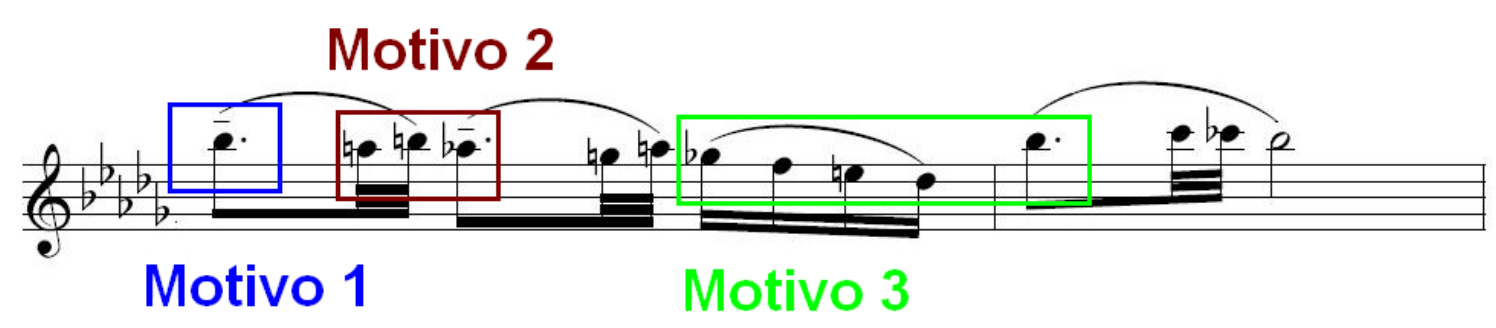




\section{VI.II - A análise Motívica}

A tabela a seguir traz todos os motivos encontrados na peça organizados da seguinte maneira: os três motivos principais estão dispostos em três fileiras, as variações foram colocadas na fileira do motivo que correspondem e indicadas no momento em que aparecem. Algumas notas foram colocadas entre parênteses porque fazem parte tanto do motivo que estão, quanto do anterior. Se o quadro for lido linha por linha, da esquerda para a direita, identificar-se-á a partitura de maneira integral

\begin{tabular}{|c|c|c|}
\hline Motivo 1 & \begin{tabular}{|l|} 
Motivo 2 \\
\end{tabular} & Motivo 3 \\
\hline \multirow[t]{3}{*}{ 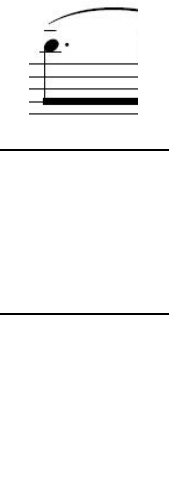 } & 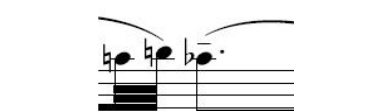 & \\
\hline & ho he be & $(b 0) \cdot 40: ?$ \\
\hline & $\begin{array}{c}\text { Variação } 1 \text { (V1) } \\
\ldots e\end{array}$ & \\
\hline \multirow[t]{5}{*}{ 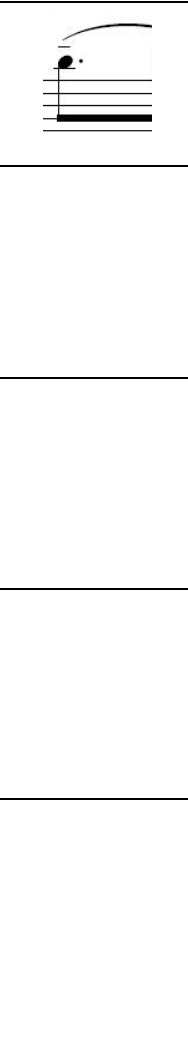 } & topele & \\
\hline & betobé & 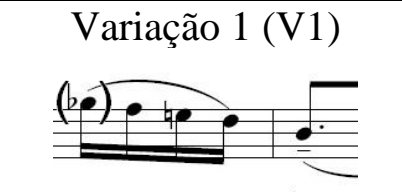 \\
\hline & Inversão da V1 (IV1) & \\
\hline & $\begin{array}{l}\text { IV1 } \\
\stackrel{3^{\prime}}{=} \\
=\end{array}$ & \\
\hline & IV1 & 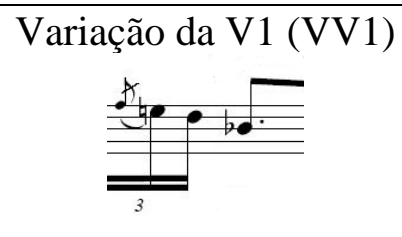 \\
\hline
\end{tabular}




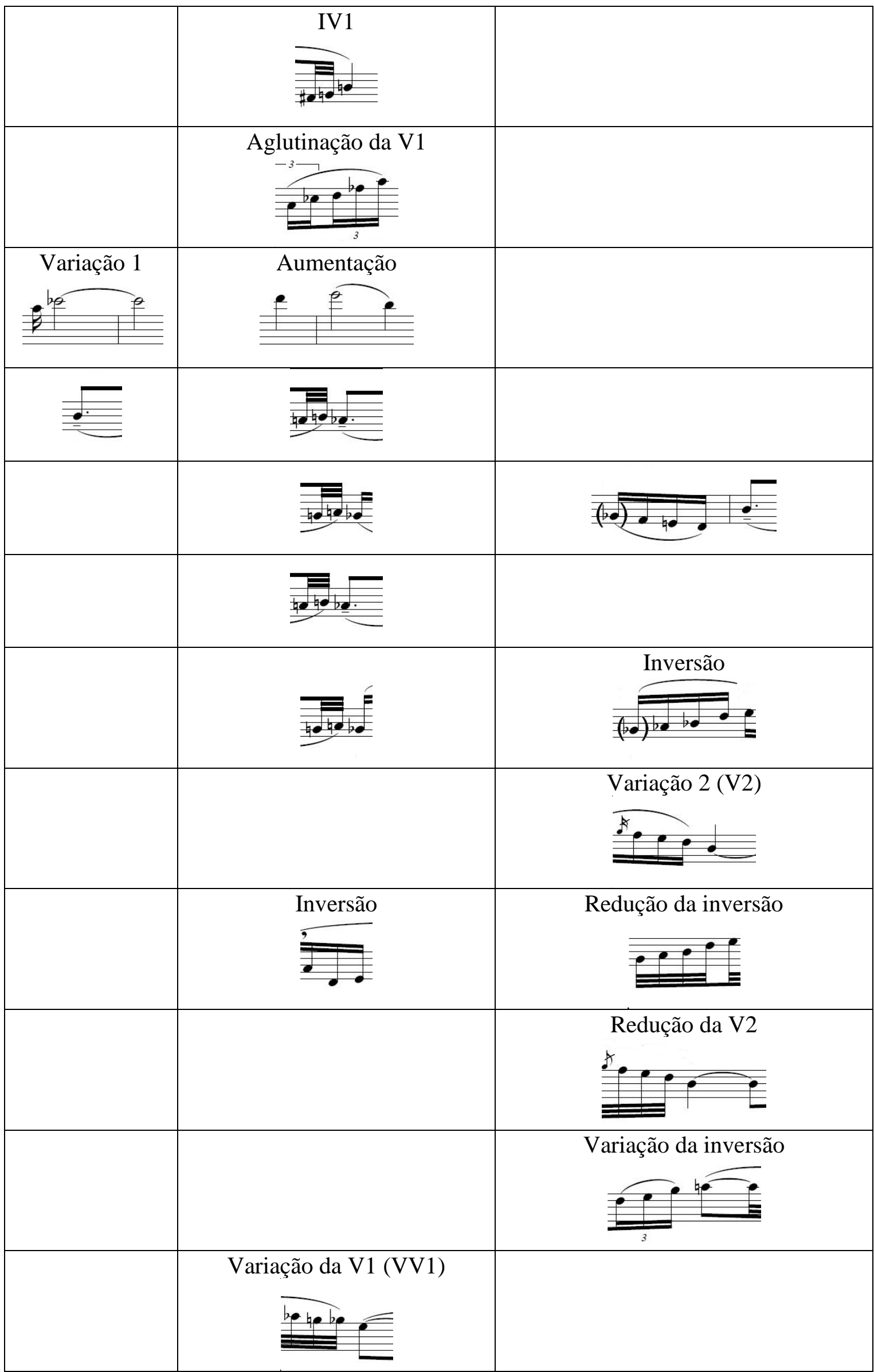




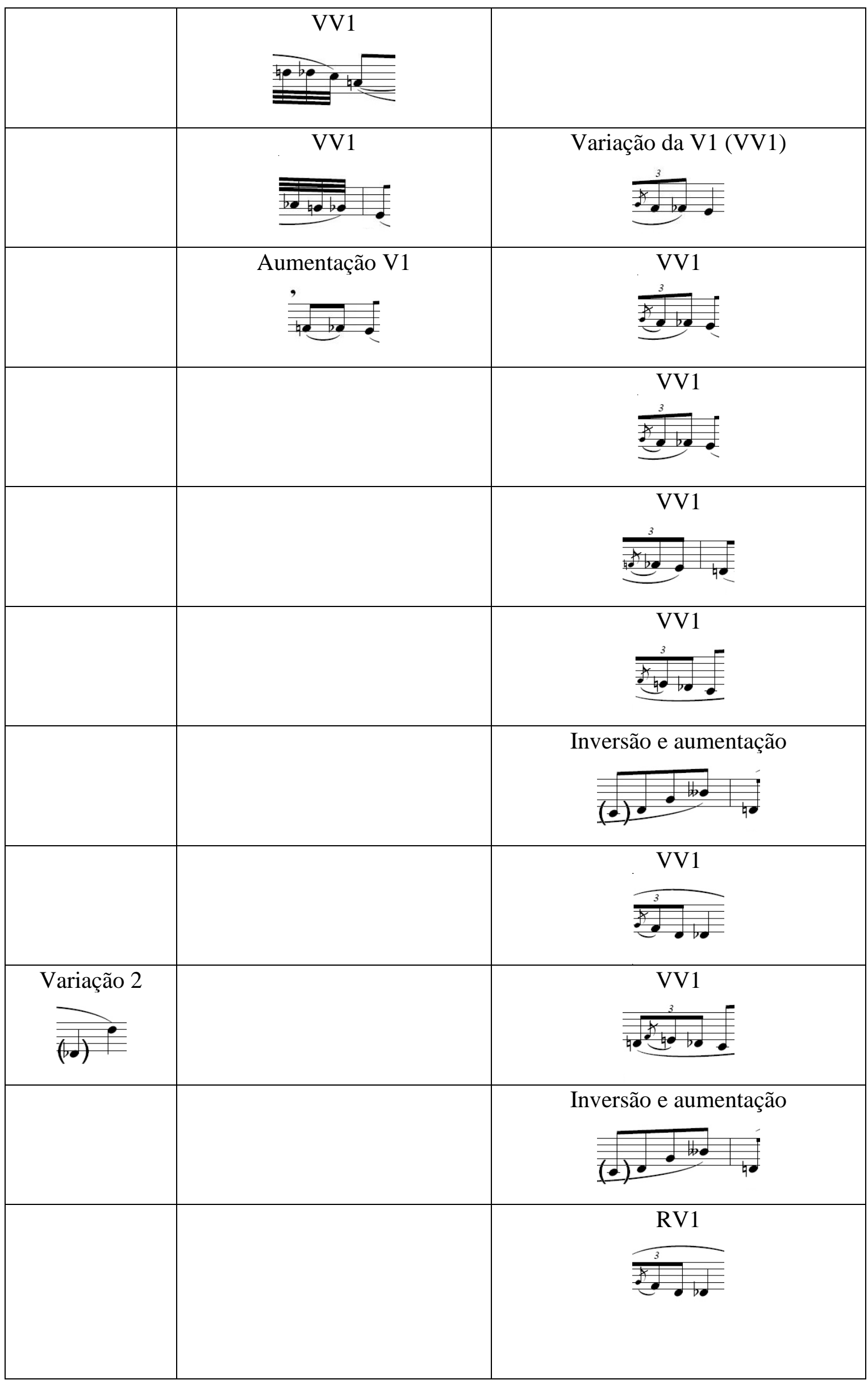




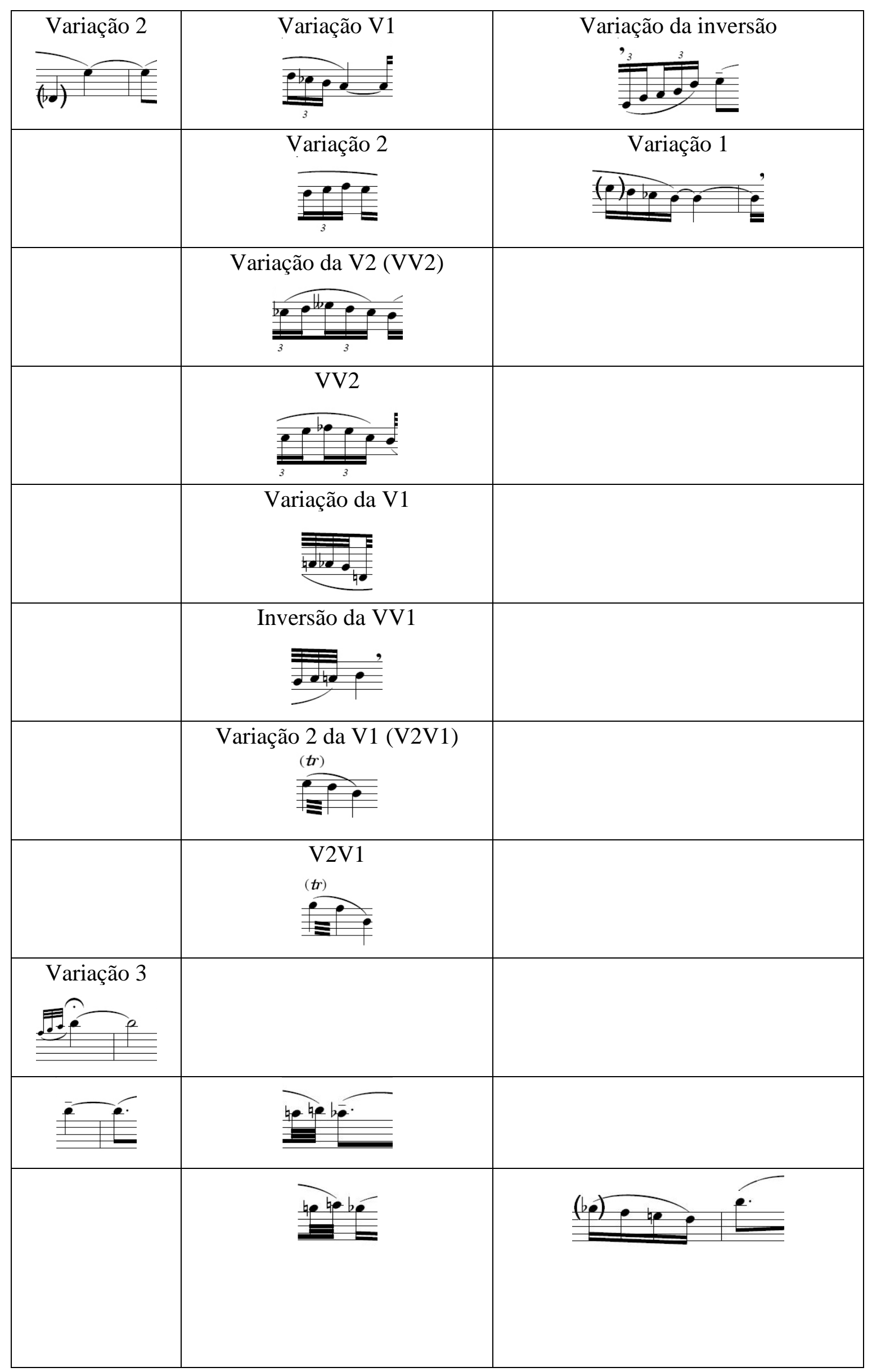




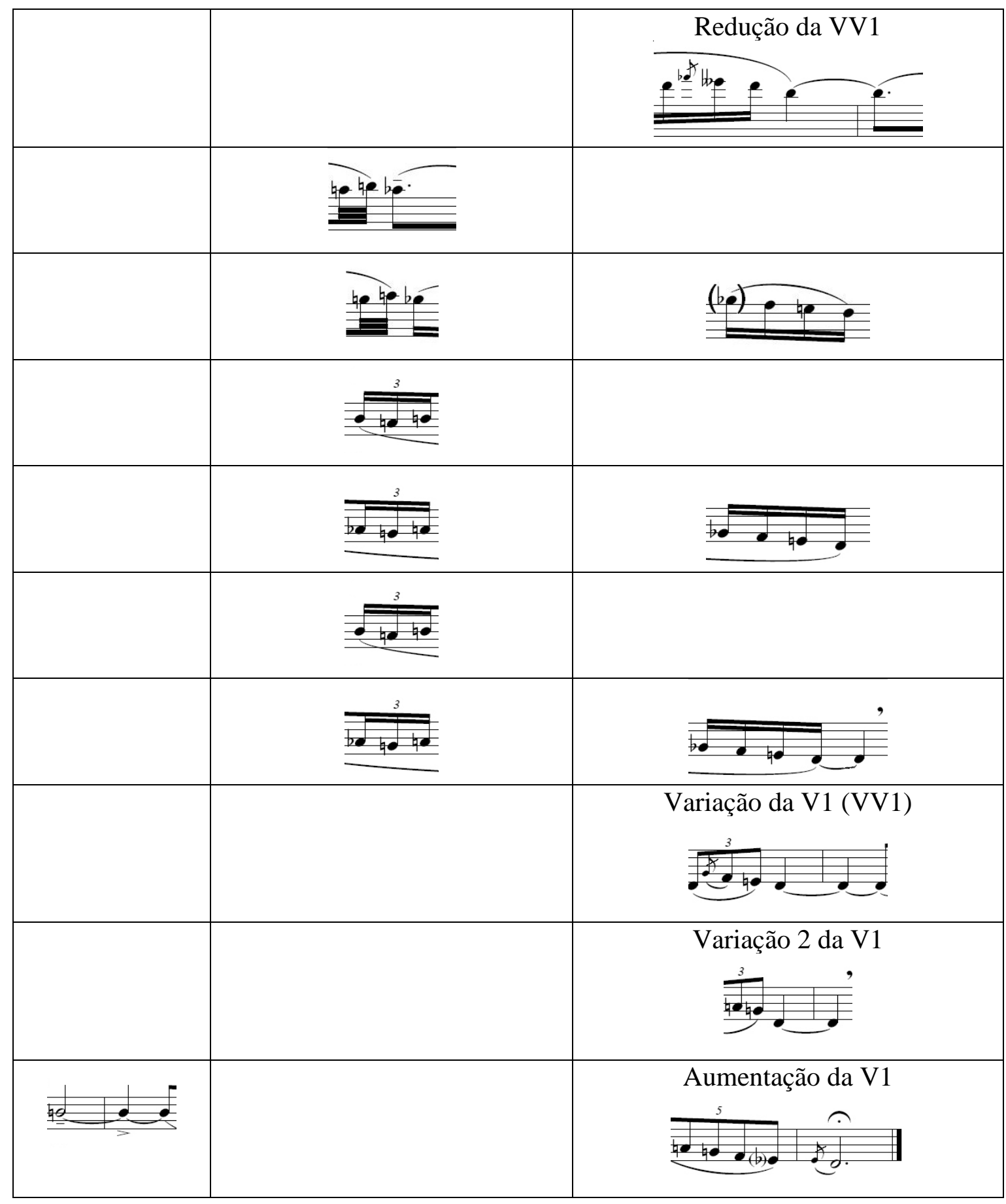

Tabela 1: análise motívica 


\section{Capítulo VII - Gráficos de Tempo e Dinâmica}

A partir do momento que uma obra musical existe na partitura, ela também existe como realidade sonora (PAREYSON apud ABDO, 2000), mas, só compreendem essa realidade aqueles que também compreendem a própria partitura. O intérprete surge então como meio de tornar "real uma composição pré-existente" (SLOBODA apud SANTIAGO 2006, p. 2) para, com teria dito Shoenberg, "uma plateia cuja infelicidade é não conseguir ler a música impressa" (NEWLIN apud COOK 2007, p. 5). Uma performance musical, "ao contrário das partituras, está no coração do mundo do ouvinte... [enquanto] as obras musicais, no mundo dos ouvintes, simplesmente não existem". (MARTIN apud COOK 2007, p. 8).

Mas, uma performance, ou interpretação musical, não é unicamente a reprodução da partitura, nela estão implícitos também características do intérprete, pois uma "performance musical é a construção e articulação de significado musical, na qual convertem todos os atributos cerebrais, corporais, sociais e históricos do executante." (CLARKE apud SANTIAGO 2006, p. 3). Todas essas implicações que 0 intérprete traz para a performance, não acrescenta a ela "nada que já não seja seu, que já não pertença à sua natureza" (PAREYSON apud ABDO 2000, p. 22).

A lei única da interpretação é a própria obra. [...] A obra e o intérprete são os dois pólos fundamentais da relação interpretativa, [...] a intencionalidade do intérprete [...] só se define como tal em contato com a obra; a intencionalidade da obra, por sua vez, só se revela quando a intencionalidade do intérprete a capta como tal. (ABDO 2000, p. 20)

Com isso, temos para uma obra musical, várias interpretações válidas, pois "nenhuma performance exaure todas as possibilidades de uma obra musical", (COOK 2006, p. 9).

A performance poderia ser compreendida como um subconjunto de um universo mais amplo de possibilidades. Mas uma maneira melhor de se pensar sobre isto é que, como coloca GODLOVITCH (1998, p.3), 'as obras subdeterminam fortemente suas performances'. Há decisões 
de dinâmica e timbre que o performer precisa tomar, mas que não estão especificadas na partitura; há nuanças de andamento que afetam essencialmente a interpretação e que fogem das especificações metronômicas explicitadas na partitura. (COOK 2006, p. 10).

Assim, para melhor executar uma obra musical, o intérprete pode optar por conhecer algumas das interpretações anteriores à sua própria, adentrando na chamada análise da performance. "A maneira mais óbvia de se estudar música enquanto performance é, simplesmente, estudar as performances que engrossam o legado das gravações." (COOK 2006, p. 15)

Existem maneiras diversas de se analisar performances gravadas. As novas tecnologias disponíveis fornecem ferramentas acessíveis para observação e análise de diversos dados da performance musical. Programas de computador tornam possível observar a abordagem do intérprete em relação à dinâmica, tempo, articulação e até mesmo vibrato.

Serão utilizadas a seguir 5 gravações que, através de gráficos gerados por um programa, serão analisadas e comparadas em alguns aspectos. Em busca de diversidade nos estilos de interpretação, foram escolhidas as seguintes gravações:

Gravação 1: Christian Lardé - francês

Gravação 2: Emmanuel Pahud - franco-suíço

Gravação 3: James Galway - irlandês

Gravação 4: Roger Bourdin - francês

Gravação 5: Terri Mitchell - americana

Todas as gravações foram editadas para terem o mesmo nível de sinal, facilitando assim as comparações de dinâmica. Também foram reguladas para terem 2 segundos de espera antes do primeiro som e outros 2 segundos depois da extinção do último som.

O programa utilizado para gerar os gráficos chama-se Sonic Visualizer, um software gratuito disponível para download no site www.sonicvisualizer.org . Seu objetivo é ser o primeiro programa utilizado para quando se quer estudar mais a fundo uma gravação, ao invés de apenas ouvi-la. O desenvolvimento desse programa se deu no Center for Digital Music, na Queen Mary University of London, tanto para que os pesquisadores do próprio centro pudessem utilizá-lo, 
como também para que o público em geral pudesse desfrutar de alguns resultados de pesquisas sobre informática obtidos ali. É útil para musicólogos e estudiosos da performance devido à gama de possibilidades de observação do fenômeno sonoro gravado, através de espectogramas e visualização de ondas (CANNAM, LANDOME \& SANDLER, 2010).

Iniciaremos a análise dos gráficos falando sobre o tempo e, a seguir, falaremos dobre dinâmica. 


\section{VII.I - Análise dos Gráficos em Relação à Tempo}

Como foi dito anteriormente, foram adicionados 2 segundos de silêncio antes do primeiro som e após o último, o que possibilita a comparação do tempo total das gravações.

Esses são os gráficos completos das gravações:

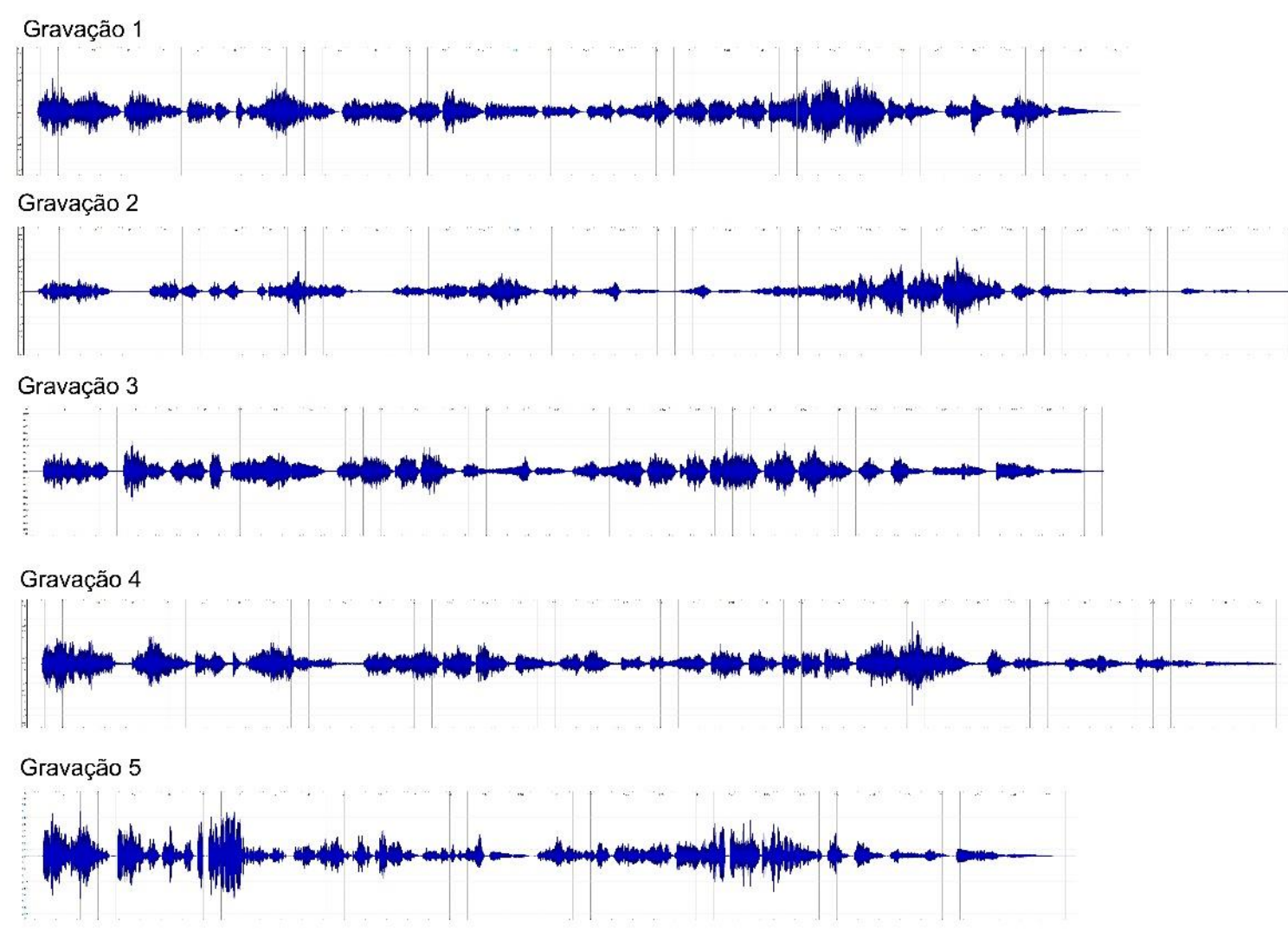

Figura 242: gráficos de tempo e dinâmica completos

Ao vermos essa imagem é possível notar que cada intérprete escolheu um tempo diferente para executar a peça, isso porque cada gráfico tem um tamanho diferente. Apesar de os gráficos das gravações 1, 3 e 5 não terem uma diferença de tamanho tão gritante (o que mostra que esses intérpretes escolheram um tempo similar), os gráficos 2 e 4 são mais longos. Assim, concluise que os intérpretes 2 e 4 escolheram um tempo mais lento.

\footnotetext{
2 Todos as imagens de gráficos têm como fonte o software SonicVisualizer
} 
Mas também é possível notar que a gravação 2 possui mais momentos de silêncio, pois seu gráfico tem vários momentos em linha reta. Seu intérprete, portanto, pode ter escolhido um tempo relativamente similar aos outros que estão sendo analisados aqui, mas deu mais ênfase às pausas e respirações, o que tornou sua gravação mais longa que as demais.

As marcações de tempo presentes na partitura de Syrinx, edição de J. Jobert, são:

\begin{tabular}{|l|l|}
\hline Compasso & Notação \\
\hline 01 & Très modéré \\
\hline 08 & Retenu \\
\hline 09 & Un peu mouvementé (mais trés peu) \\
\hline 15 & Cédez \\
\hline 16 & Rubato \\
\hline 26 & Au Mouvt (très modéré) \\
\hline 31 & Em retenant jusqu'à la fin \\
\hline 34 & Très retenu \\
\hline
\end{tabular}

Tabela 2: indicações de andamento

A seguir vemos os gráficos divididos em compassos. O software Sonic Visualizer até faz uma divisão de compassos aproximada, porém, essa peça não tem marcações precisas entre um compasso e outro, o que tornou a divisão feita pelo software não muito precisa. As divisões de compasso, então, foram feitas manualmente. É necessário pontuar que essa divisão é aproximada, não é absolutamente precisa, pois alguns compassos iniciam-se com uma nota ligada. 
Gravação 1

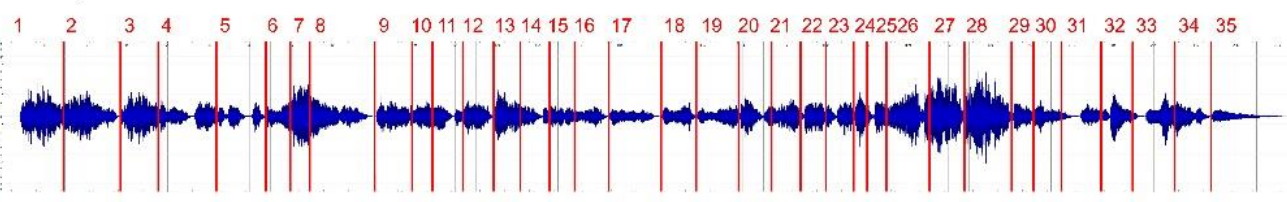

Gravação 2
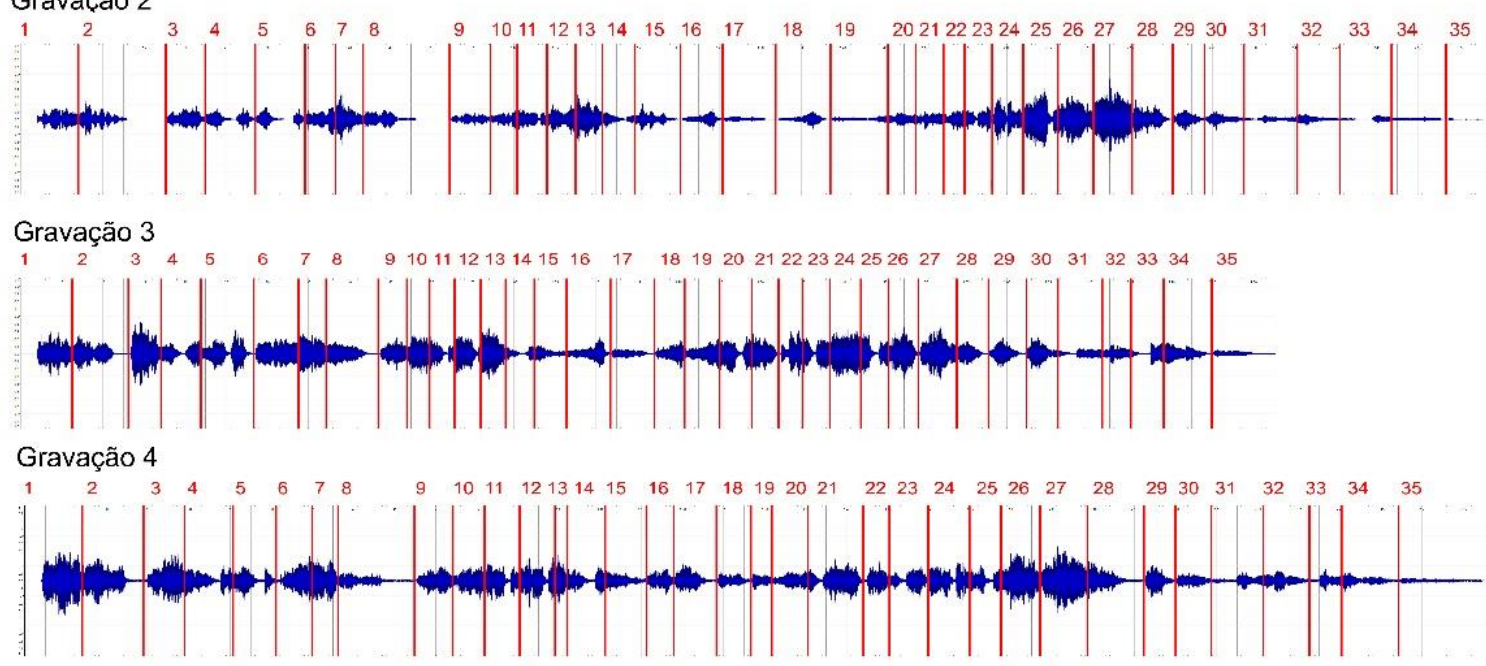

Gravação 5

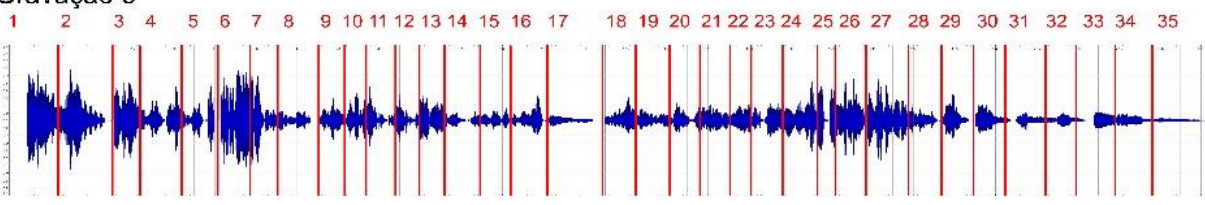

Figura 25: gráficos de dinâmica e tempo com barras de compasso

De início já pode-se notar que o tempo dessa peça é, em geral, bem livre. Em uma música com tempo fixo, os compassos teriam, no gráfico, todos o mesmo tamanho. Aqui vê-se diferenças entre os tamanhos dos compassos dentro da mesma gravação, mostrando que, realmente, o tempo dessa peça não é fixo.

Os 8 primeiros compassos têm a marcação de andamento Très modéré, o compasso 8 tem a marcação Retenu Abaixo temos a partitura e os gráficos com os compassos de 1 a 8 . 

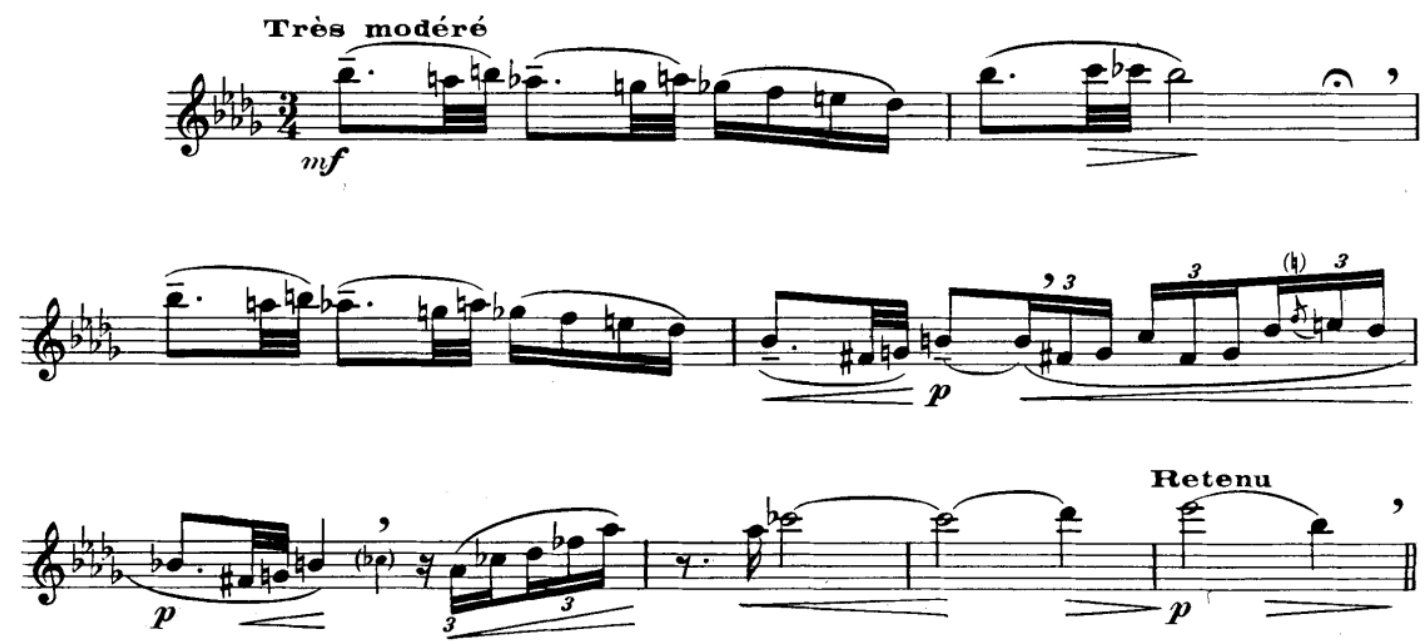

Gravação 1

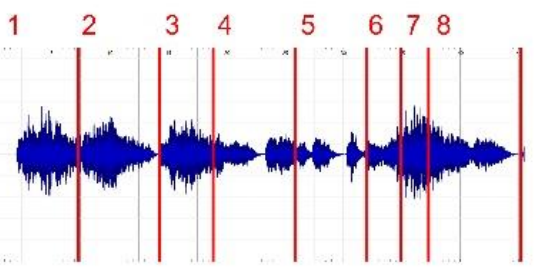

Gravação 2

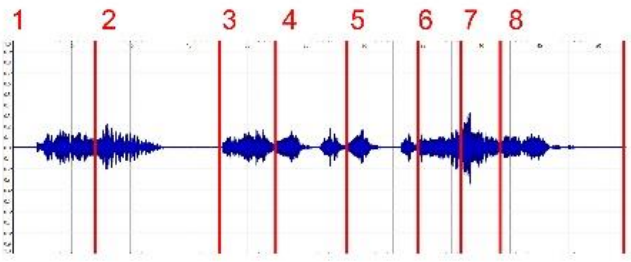

Gravação 3

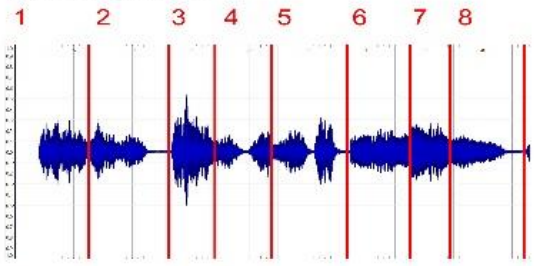

Gravação 4

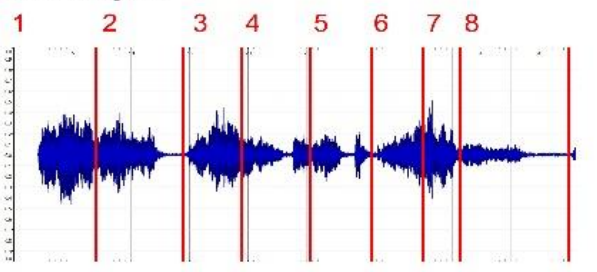

Gravação 5

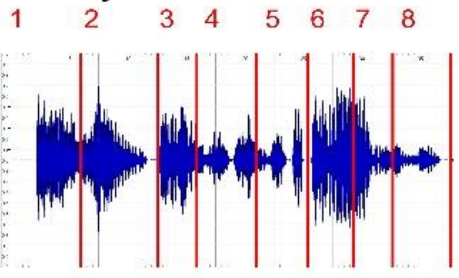

Figura 26: partitura e gráficos compassos 1 ao 8 
Em relação ao primeiro e segundo compassos, o compasso 3 ficou mais andado em todas as gravações, apesar de ser exatamente igual ao primeiro. Isso mostra que todos os intérpretes buscaram fazer algo diferente nessa repetição, talvez para que a música não soasse repetitiva.

Por serem ligados por uma nota longa, a divisão entre os compassos $6 \mathrm{e}$ 7 não é precisa. Entretanto, o início do sexto compasso e o final do sétimo são. É possível notar que esses dois compassos foram feitos mais rápido em todas as gravações. Talvez ninguém tenha pensado em dar tanta ênfase à nota longa que está presente nesses compassos, ou então os intérpretes escolheram fazer essa nota mais curta porque segurar uma mesma nota por tanto tempo pode não ser tão agradável aos ouvintes. Nessa visão, os intérpretes escolheram fazer a nota longa mais andada para que a frase dos compassos 6, 7 e 8 fizesse mais sentido aos ouvintes.

O compasso 8 é mais longo em todas as gravações, porém, na gravação 2 o tempo em silêncio é maior que todas as outras.

Do compasso 9 ao 25, a marcação de andamento é Un peu mouvementé (mais trés peu), tendo no compasso 15 uma marcação de Cedez e no 16 uma de Rubato. 
Un peu mouvementé (mais très peu)
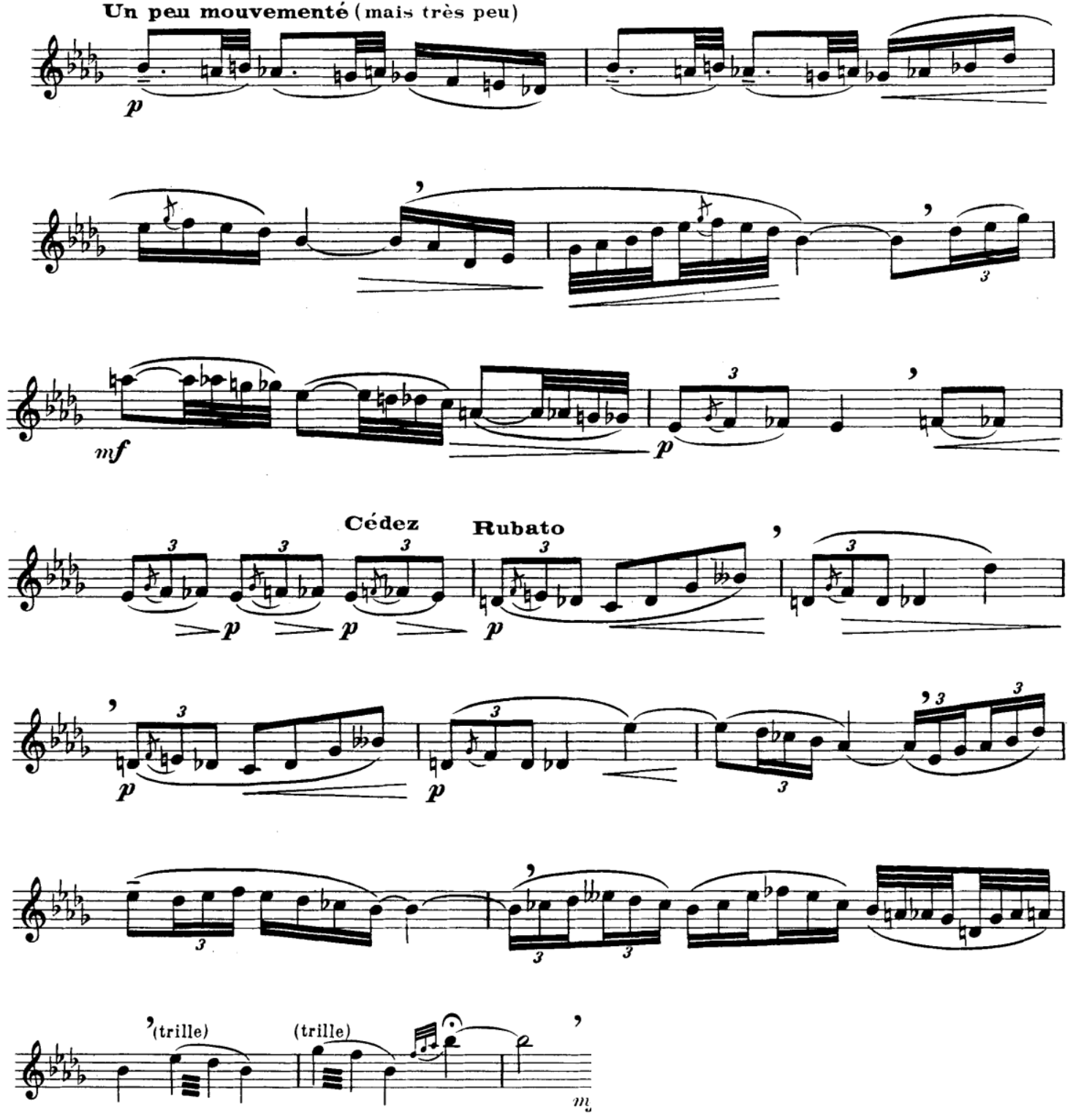


\section{Gravação 1}

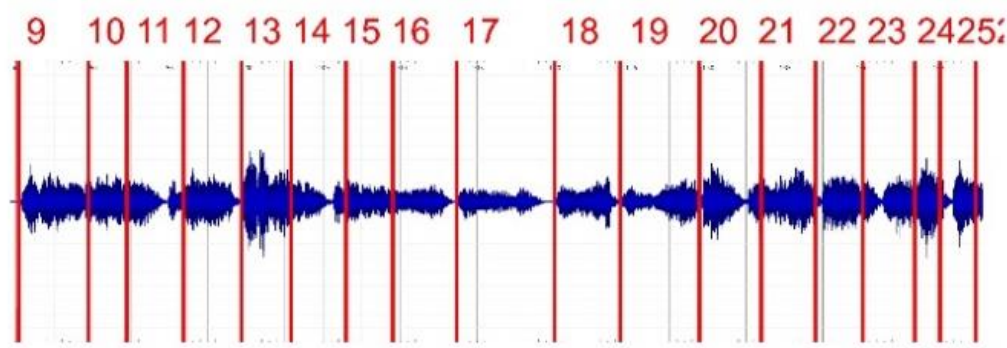

Gravação 2

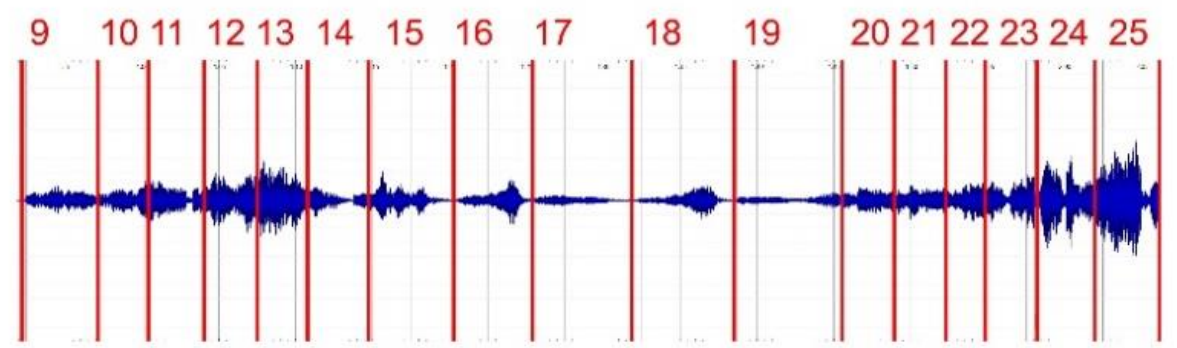

\section{Gravação 3}

$910111213141516 \quad 17 \quad 1819202122232425$ :

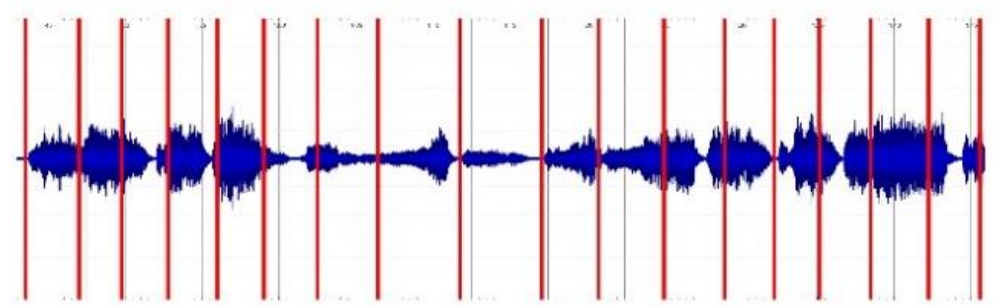

Gravação 4

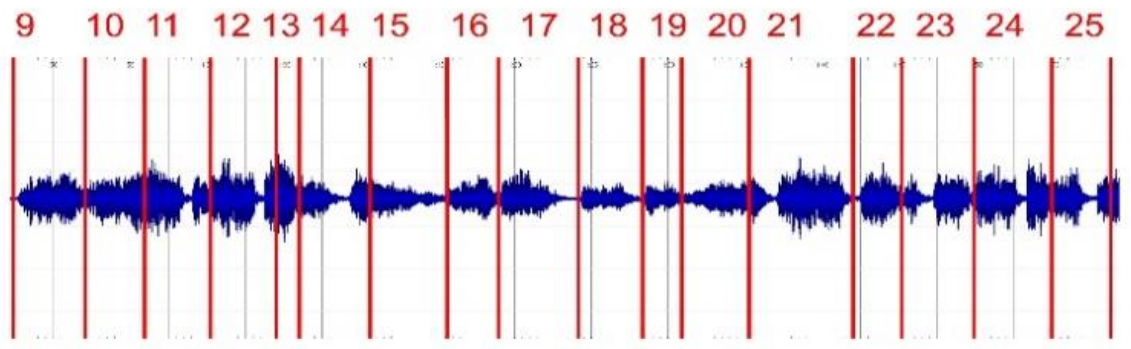

\section{Gravação 5}

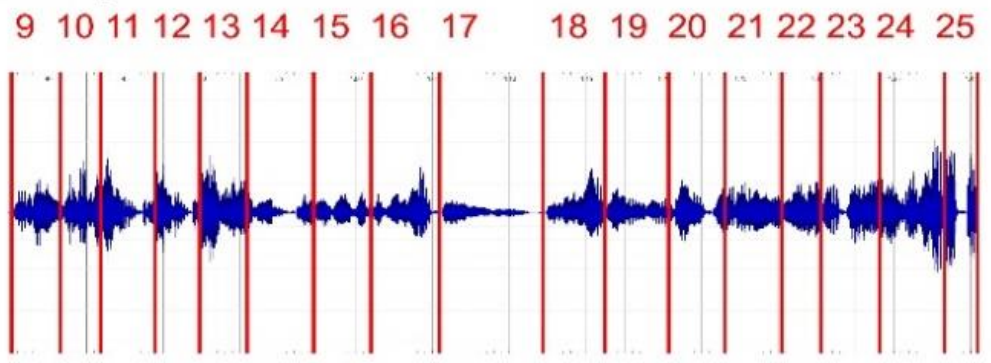

Figura 27: partitura e gráficos compassos 9 ao 25 . 
Novamente é necessário ressaltar que as divisões entre os compassos 19 e 20, e 20 e 21 não são totalmente precisas, pois esses compassos possuem uma nota ligada entre eles.

Nota-se que todas as gravações realmente fizeram o tempo um pouco mais agitado, como foi pedido na partitura. Apesar de o ritmo dos compassos 9 e 10 ser igual, os intérpretes das gravações 1,2 e 4 escolheram fazer 0 compasso 9 um pouco mais lento. É possível notar esse fato pois o gráfico mostra o compasso 9 maior que o 10. Como não há indicação nenhuma para essa mudança de andamento, conclui-se que essa é uma escolha performática.

O compasso 15 tem a marcação Cedez. Entretanto, nos gráficos não se nota nenhuma diferença gritante em seu tamanho, o que mostra que o tempo desse compasso foi feito quase igual ao tempo anterior.

No gráfico da gravação 1, os compassos 13, 14 e 15 tem praticamente o mesmo tamanho. O compasso 16, que está marcado com Rubato, é um pouco maior. No gráfico 2, o compasso 15 é um pouco maior que o 13 e o 14, mas seu tamanho é quase igual ao compasso 16. No terceiro gráfico, o compasso 15 é também um pouco maior que o 13 e 14, mas é menor que o 16. No gráfico 4, 0 compasso 13 é pequeno, o 14 e o 15 tem basicamente o mesmo tamanho e o 16 é menor que o 15. No último gráfico, o compasso 14 é maior que o 13, e quase do mesmo tamanho que o 15 e o 16 . Isso mostra que cada intérprete escolheu um modo de fazer esse trecho, independente das marcações de tempo.

O compasso 17 é mais longo em todas as gravações. Apesar de não haver nenhuma indicação de mudança de tempo nele, todos os intérpretes o fizeram mais longo.

Nos gráficos 1, 3 e 5, os compassos 18, 19, 20 e 21 tem basicamente 0 mesmo tamanho, mostrando que os intérpretes mantiveram o tempo constante nesse trecho. No gráfico 2, os compassos 18 e 19 estão maiores que os próximos, e no gráfico 4, os compassos 18 e 20 tem mais ou menos o mesmo tamanho, enquanto o 19 é menor e o 21 é maior. Considerando que o ritmo começa a se intensificar no final do compasso 20 e no compasso 21, pode-se concluir que 0 intérprete da gravação 2 escolheu fazer o tempo mais agitado juntamente com a intensificação do ritmo escrito. $O$ intérprete da gravação 5 talvez possa ter buscado essa agitação fazendo mais curta a nota longa do final do compasso 19. 
Não é possível determinar com certeza onde o compasso 24 termina e o 25 começa, mesmo assim algumas observações podem ser feitas. Na gravação 1 , os compassos 24 e 25 foram feitos mais rápidos que os compassos 22 e 23 , enquanto que nas gravações 2,3 e 4, foram feitos basicamente no mesmo andamento. Na gravação 5, o compasso 25 é feito bem rápido, o que pode ter sido proposital, mas também existe a possibilidade da nota longa ter ficado mais curta por falta de ar.

A próxima marcação de andamento encontra-se no compasso $26, A u$ Mouvt (très modéré), e mantem-se até o compasso 30.
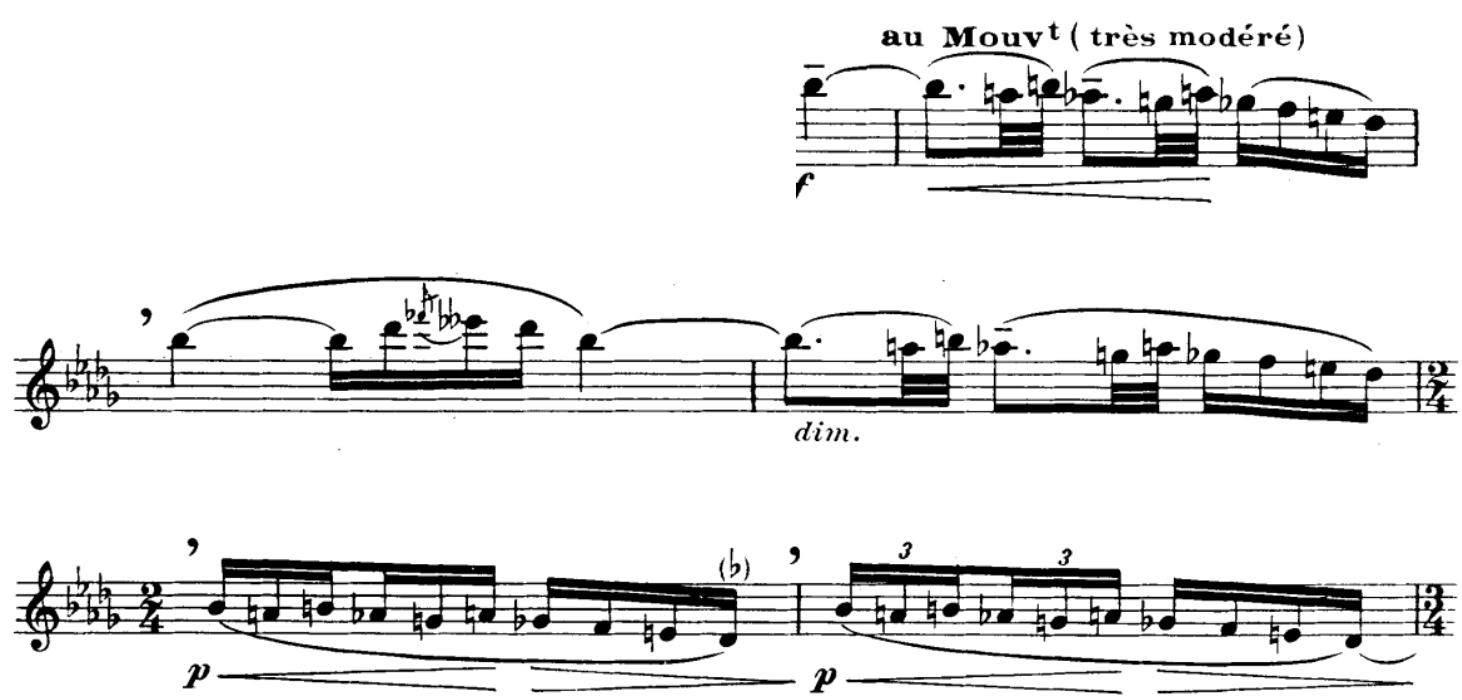


\section{Gravação 1}

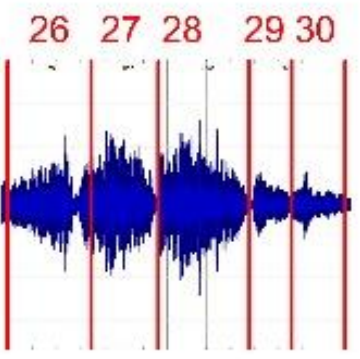

\section{Gravação 2}

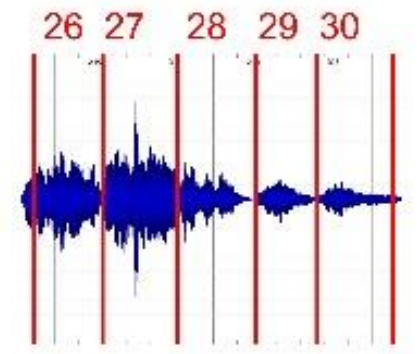

Gravação 3

$\begin{array}{lllll}26 & 27 & 28 & 29 & 30\end{array}$

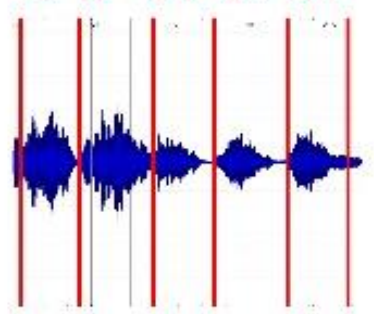

Gravação 4

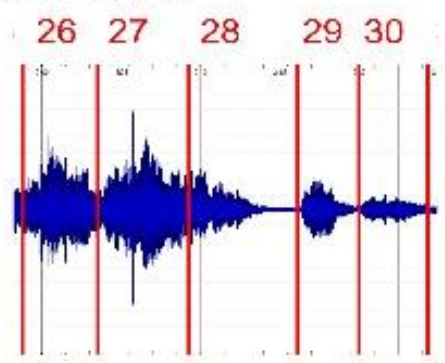

Gravação 5

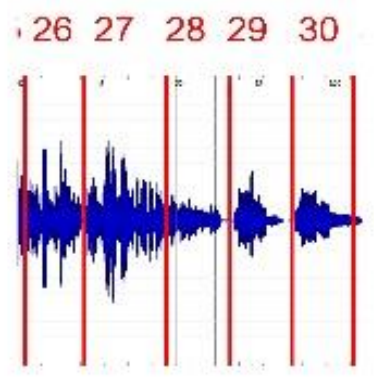

Figura 28: partitura e gráficos compassos 25 ao 30 
Na gravação 1, os compassos 26, 27 e 28 são feitos quase no mesmo andamento, e os compassos 29 e 30 são feitos mais rápido, apesar de não haver indicação de mudança de andamento. Porém, a mudança de oitava e a indicação de diminuendo no compasso 28 dão margem a uma escolha interpretativa nesse momento. No caso da gravação 1, o intérprete escolheu fazer os compassos 29 e 30 mais rápidos que os anteriores. O intérprete também escolheu fazer 0 compasso 28 mais longo, coisa que os intérpretes das gravações 2 e 4 também escolheram fazer. Na gravação 2, o compasso 30 é feito ainda mais longo que 0 29.

As próximas marcações de tempo se encontram nos compassos 31 e 34 . 
En retenant jusqu'ù la fin.

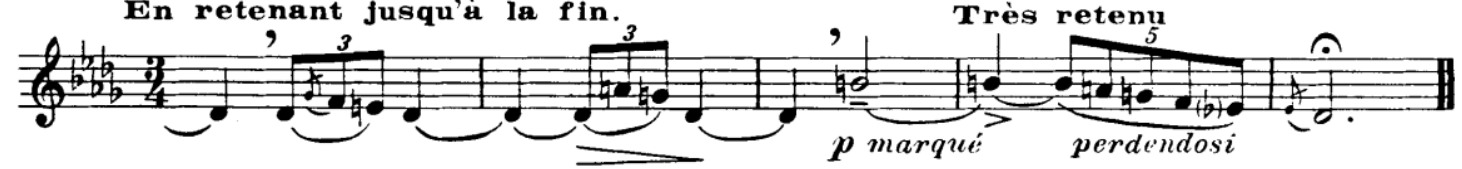

Gravação 1

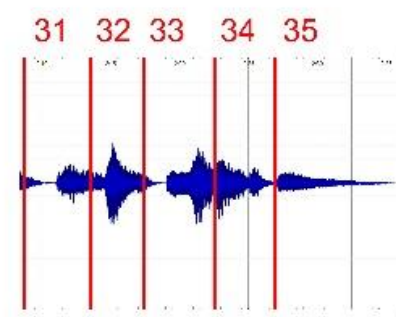

\section{Gravação 2}

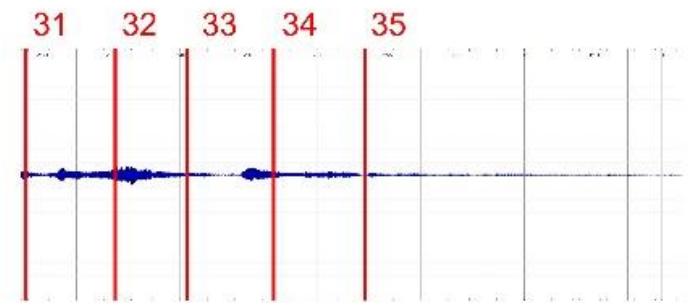

Gravação 3

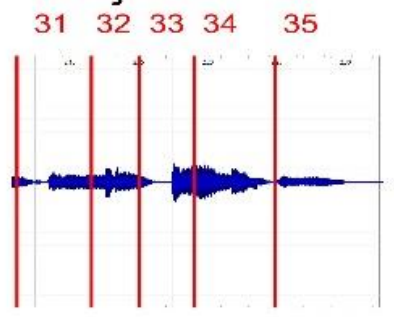

Gravação 4

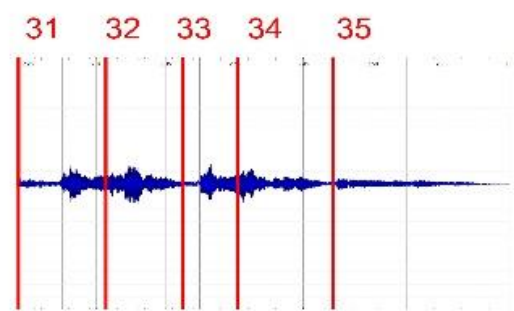

Gravação 5

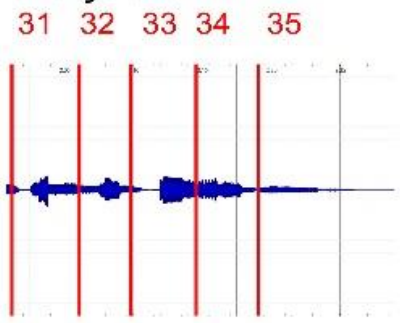

Figura 29: partitura e gráficos compassos 31 a 35 
Com exceção da gravação 3 , que fez os compassos 32 e 33 mais rápidos que os outros desse trecho, todos os intérpretes analisados aqui seguiram a indicação de fazer o tempo mais lento. Porém, não se vê nos gráficos um aumento do tamanho dos compassos até o fim, que seria o esperado de acordo com a indicação En retenant jusqu'a la fin. O compasso 34 é marcado com a indicação Très retenu, e apenas nos gráficos 3 e 4 pode-se ver que este compasso foi feito um pouco mais lento que os anteriores. O compasso 35 é o último da música, uma nota longa com uma fermata após indicações de redução do tempo. É esperado que os intérpretes o façam de forma bem lenta, o que se pode verificar nos gráficos, sendo o mais longo de todos o da gravação 2 . 


\section{VII.II - Análise dos Gráficos em Relação à Dinâmica}

A partitura de Syrinx pede para que o início da música seja tocado em dinâmica mezzoforte. Aparecem 3 mezzofortes em toda a peça: no compasso 1, no compasso 13 e no 25 . A seguir será mostrada um "mapa" das dinâmicas pedidas na partitura.

\begin{tabular}{|c|c|c|c|}
\hline 1 & 2 & 3 & 4 \\
\hline$m f$ & $=\mathrm{A}$, & & $\longrightarrow p, \Longrightarrow$ \\
\hline 5 & 6 & 7 & 8 \\
\hline$=p$, & 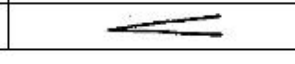 & $=$ & $p=$, \\
\hline
\end{tabular}

\begin{tabular}{|l|l|l|l|}
\hline 9 & 10 & 11 & 12 \\
\hline $\boldsymbol{p}$ & $-\underline{二}$ &,$\quad$ \\
\hline
\end{tabular}

\begin{tabular}{|c|c|c|c|}
\hline 13 & 14 & 15 & 16 \\
\hline $\boldsymbol{m} \boldsymbol{f}=\boldsymbol{p}$ & $\boldsymbol{p}, \boldsymbol{p} \rightleftharpoons \boldsymbol{p}$ & $\boldsymbol{p} \rightleftharpoons$ \\
\hline
\end{tabular}

\begin{tabular}{|c|c|c|c|}
\hline 17 & 18 & 19 & 20 \\
\hline$=$ & $p$ & $p$ & $\boldsymbol{p}$ \\
\hline
\end{tabular}

\begin{tabular}{|l|l|l|l|}
\hline 21 & 22 & 23 & 24 \\
\hline & $\boldsymbol{9}$ & $\boldsymbol{9}$ & $\curvearrowright$ \\
\hline
\end{tabular}

\begin{tabular}{|c|c|c|c|}
\hline 25 & 26 & 27 & 28 \\
\hline, $\boldsymbol{m} \boldsymbol{f}$ & - &, & dim. \\
\hline
\end{tabular}

\begin{tabular}{|c|c|c|c|}
\hline 29 & 30 & 31 & 32 \\
\hline $\boldsymbol{p}=$ &, $\boldsymbol{p} \rightleftharpoons$ &, & $\Xi$ \\
\hline
\end{tabular}

\begin{tabular}{|c|c|c|}
\hline 33 & 34 & 35 \\
\hline $\boldsymbol{p}$ marque & $\boldsymbol{p e r d e}$ ndosi & $\curvearrowright$ \\
\hline
\end{tabular}

Figura 30: dinâmicas presentes em Syrinx

Não será abordado aqui o nível de decibéis de cada dinâmica escrita e sim as relações entre dinâmicas. Serão examinadas relações entre uma gravação e outra e também dentro de uma mesma gravação. Iniciaremos com 
as gravações individuais. Para facilitar a visualização, serão novamente utilizados os gráficos divididos em compassos.

\section{Gravação 1}

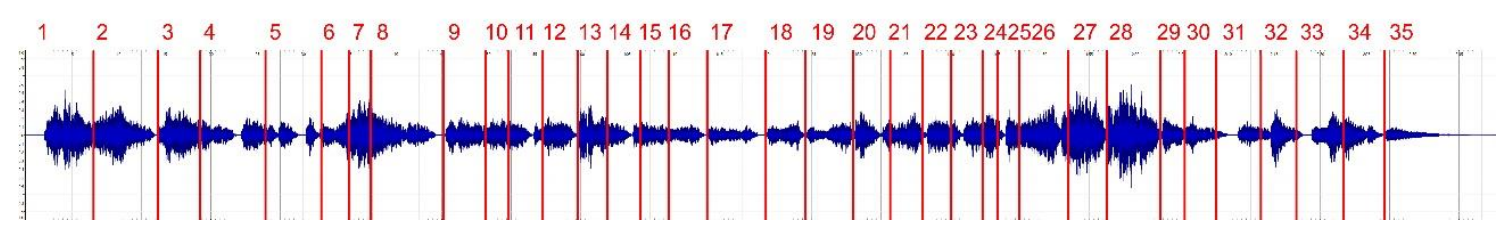

Figura 31: gráfico gravação 1 com barras de compasso

A dinâmica do compasso 1 mantem-se até o compasso 2, onde 0 intérprete faz um crescendo antes de fazer o decrescendo que está escrito na partitura. O compasso 3 inicia-se um pouco mais piano que o compasso 1 , mas apenas um pouco, a dinâmica é praticamente a mesma e há, nesse compasso, um decrescendo, pois o compasso 4 está mais piano. Na partitura, não há dinâmica marcada no compasso 3, e no compasso 4 há um crescendo seguido de um piano. Esse intérprete fez o piano apenas. Ainda no compasso 4, não houve o crescendo marcado. A escolha da dinâmica dos compassos 6,7 e 8 foi diferente do que está escrito na partitura. Esse intérprete fez um grande crescendo nos compassos 6 e 7, culminando no compasso 8, e só então fez um decrescendo.

Os compassos 9, 10 e 11 mantem-se basicamente na mesma dinâmica, que é bem mais suave que a dinâmica do início da peça. Pode-se ver o decrescendo marcado no compasso 11, porém o crescendo do compasso 12 não acontece. O compasso 13 é marcado com mezzoforte, e pode-se ver que o intérprete da gravação 1 fez uma dinâmica mais intensa quase que súbita. Comparando-se esse mezzoforte com o mezzoforte do compasso 1, vê-se que a dinâmica do compasso 13 é menos intensa que a do compasso inicial da peça. É possível ver, também, que o decrescendo escrito no compasso 13 aconteceu. Os compassos 15, 16 e 17, mantém-se praticamente na mesma dinâmica.

No compasso 18 para o 19 vê-se bem o crescendo seguido de piano. No compasso 20 há um pico na dinâmica, seguindo o crescendo que está marcado. Os compassos 21, 22 e 23, mantém-se quase na mesma dinâmica. O compasso 
24 tem a dinâmica um pouco mais intensa que os compassos anteriores. $O$ compasso 25 tem um mezzoforte marcado, pelo gráfico vê-se que esse intérprete iniciou a nota do compasso 25 na mesma dinâmica do compasso 24 , fazendo o crescendo do compasso 26 conforme indicado na partitura. Os compassos 27 e 28 são, em toda peça, os mais fortes. No compasso 28 podese ver que o intérprete seguiu o diminuendo que está marcado.

No compasso 32 há um aumento da dinâmica que não está marcado na parte. No compasso 33 há o marcato, que na edição de J. Jobert é um acento escrito na nota e uma marcação de marqué, porém, no manuscrito de Bruxelas é um decrescendo. Pelo gráfico é possível ver que esse intérprete escolher fazer o marcato sugerido pela edição de J. Jobert, seguindo-se de um grande diminuendo até o final da peça.

\section{Gravação 2}

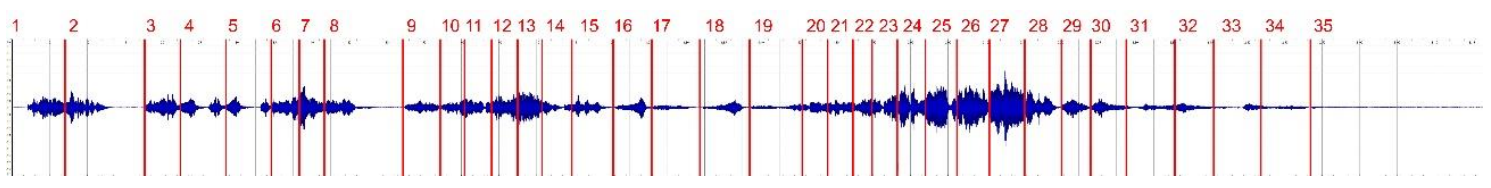

Figura 32: gráfico gravação 2 com barras de compasso

Pode-se ver por esse gráfico, que o intérprete da gravação 2 escolheu fazer um pequeno diminuendo no compasso 1 , retomando (na verdade, indo até um pouco mais além) a dinâmica no compasso 2. Vê-se, nesse compasso, que o diminuendo escrito realmente acontece.

No compasso 4, pode-se ver que o intérprete fez o crescendo enquanto o compasso 5 se inicia mais piano. Nos compassos 6, 7 e 8, é visível o crescendo e o diminuendo marcados na partitura.

O compasso 9 está marcado com um piano, e, comparando-se com a dinâmica do compasso 1 , vê-se que o intérprete seguiu a dinâmica escrita na partitura. Vê-se também um leve crescendo seguido de um decrescendo.

O compasso 13 está marcado com um mezzoforte. Comparando desenho gerado pelo gráfico nesse compasso com o do compasso 1 , é visível que a dinâmica do compasso 13 está um pouco mais forte do que a do compasso 1. 
O compasso 14, marcado com piano, tem a dinâmica mais suave do que os compassos 4 e 5, que também estão marcados com piano. Os compassos 15 e 16 têm crescendo e decrescendos que são visíveis. No compasso 18, pode-se ver o crescendo seguido de um piano no compasso 19.

A próxima marcação de dinâmica é no compasso 25 , mas no gráfico é visível que o intérprete da gravação 2 escolher fazer um grande crescendo que iniciou-se no compasso 20 , recuou um pouco no compasso 24 , e voltou com mais intensidade para chegar no compasso 25. Mas o ápice de intensidade se dá no compasso 27, onde, apesar de não haver nenhuma dinâmica escrita, pode-se entender um cume da dinâmica, pois no compasso 26 há um crescendo e no 28 um diminuendo.

Nos compassos 29 e 30, vê-se que a onda aumenta e diminui, mostrando que o intérprete fez os crescendos e diminuendos marcados nesses compassos. Depois disso segue-se um grande diminuendo até o final da peça.

Agora em se tratando do marqué do compasso 33, esse intérprete escolheu fazer um pequeno acento no início da nota, e seguir com um diminuendo. Percebe-se pelo gráfico que ele escolheu não fazer o acento no meio da nota longa.

O compasso 35 é feito tão piano que chega a ser um pouco difícil visualizá-lo no gráfico. Quase não se vê onde termina a nota final.

\section{Gravação 3}

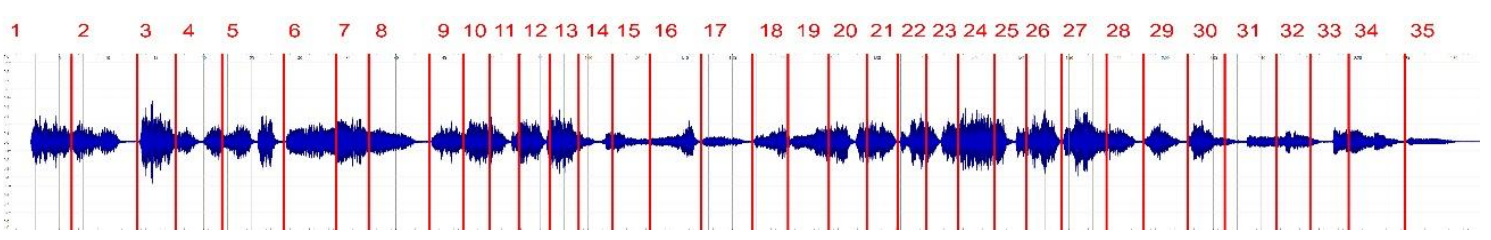

Figura 33: gráfico gravação 3 com barras de compasso

A dinâmica nessa gravação mantém-se estável durante o primeiro compasso e o início do segundo, seguindo-se do diminuendo marcado na parte. O terceiro compasso inicia-se numa dinâmica mais intensa que o primeiro, apesar de não haver marcação nenhuma de dinâmica nele. Sendo o terceiro 
compasso é uma repetição do primeiro, pode-se dizer que esse intérprete escolheu fazer essa mudança para que o tema ficasse diferente nessa repetição.

O compasso 4 está marcado com um crescendo seguido de um piano, mas pelo gráfico nota-se que o intérprete da gravação 3 escolheu fazer um diminuendo no compasso 4, ou, talvez até um piano súbito, pois o gráfico diminui bruscamente de tamanho nesse local. Porém, fica visível que o intérprete seguiu - crescendo seguido de piano marcados no compasso 4 para o 5 e os crescendos e diminuendos marcados nos compassos 5, 6 e 7. O compasso 8 tem a marcação de piano com decrescendo e pode-se ver que o intérprete seguiu o que está escrito na partitura. Também é interessante ver que os compassos 4, 5 e 8, que são os que têm marcação de piano, têm seu desenho no gráfico quase do mesmo tamanho.

O compasso 9 tem a marcação de piano e o crescendo está marcado no compasso 10, mas é possível ver que no compasso 10 esse intérprete não fez um crescendo e sim uma dinâmica mais intensa subitamente. O decrescendo do compasso 11 é visível no gráfico, porém, no compasso 12 novamente não há um crescendo e sim um aumento súbito na dinâmica. O compasso 13, nesse trecho, é o mais intenso, o que vai de encontro ao que está escrito na partitura, que é um mezzoforte. O decrescendo marcado no final do compasso 13 é bem rápido e brusco, pois o compasso 14 tem a dinâmica mais suave que apareceu nessa gravação até agora.

O compasso 14 tem um crescendo indo para o compasso 15, e logo após há três decrescendos e dois pianos marcados, neste mesmo compasso. É possível ver que o decrescendo do início do compasso 15 aconteceu nessa gravação. Mas, depois disso, esse compasso se mantém basicamente na mesma amplitude de dinâmica. O compasso 16 tem um crescendo que culmina no início do compasso 17, e depois há um decrescendo. Esse intérprete, entretanto, escolheu fazer um grande crescendo no final do compasso 16, seguido de um piano súbito no início do compasso 17.

No compasso 18, o intérprete seguiu o que foi pedido na partitura, piano, crescendo seguido de piano no início do compasso 19. Do compasso 19 até o 24, pode-se ver que há um aumento na intensidade da dinâmica, que culmina no compasso 23 e 24. A dinâmica do compasso 25 é igual à do compasso 24 , apesar do mezzoforte escrito na partitura. O compasso 26 se inicia mais suave 
que o 25, o crescendo marcado acontece e no compasso 27 há um pequeno pico na dinâmica, que não ultrapassa a dinâmica usada nos compassos 24 e 25.

Nos compassos 33 e 34 fica claro que esse intérprete escolheu fazer 0 marcato escrito na nota longa. Depois segue-se um grande diminuendo até o final da peça.

\section{Gravação 4}

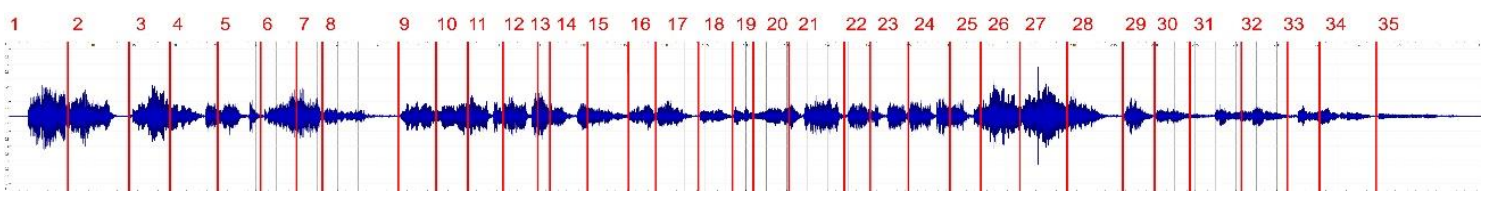

Figura 34: gráfico gravação 4 com barras de compasso

O intérprete da gravação 4 fez um diminuendo no compasso 2 conforme está indicado na partitura. A dinâmica do compasso 3 se inicia mais suave que a do compasso 1, mostrando que nessa repetição do tema, o intérprete escolheu fazer uma mudança de dinâmica, mesmo sem estar escrito na partitura. Ele inicia o compasso mais piano e faz um crescendo seguido de um decrescendo, e começa o compasso 4 numa dinâmica mais suave, não seguindo o crescendo seguido de piano que está escrito. Nos compassos 6,7 e 8 , vê-se que o intérprete seguiu os crescendos e diminuendos marcados.

A dinâmica do compasso 9 está bem mais suave que a dinâmica do início, mostrando que o intérprete seguiu o piano escrito nesse compasso. Nesse trecho não há muita alteração de dinâmica, apenas no compasso 13 um pequeno aumento na intensidade da dinâmica, que é onde há um mezzoforte marcado na partitura. Comparando-se esse compasso com o primeiro, que também está marcado com mezzoforte, vê-se que o compasso 13 foi feito com a dinâmica mais suave que a dinâmica inicial. A diferença de dinâmica entre os compassos 13 e 14 também não é muito grande, apesar deles estarem marcados com mezzoforte e piano, respectivamente.

O compasso 15 é feito com um diminuendo que dura o compasso todo, e do 16 para o 17 pode-se ver o crescendo seguido de diminuendo. Os compassos 18 e 19 são feitos bem piano e há um pequeno crescendo no compasso 20 . O final do compasso 25 está marcado com um mezzoforte, mas ele não acontece, 
pois a dinâmica mantem-se igual à dos compassos anteriores. No compasso 26 é possível ver que houve um aumento meio súbito na dinâmica, que mantem-se no compasso 27. O compasso 28 tem o diminuendo sugerido na partitura.

No compasso 29, vê-se que o intérprete fez um pouco o crescendo e diminuendo que estão marcados, mas no 30 , que tem as mesmas marcações, a dinâmica mantém-se constante. No compasso 33, o intérprete iniciou a nota com um pequeno acento, e no início do compasso 34, ele novamente fez um pequeno acento. E depois há um decrescendo até o final da peça.

\section{Gravação 5}

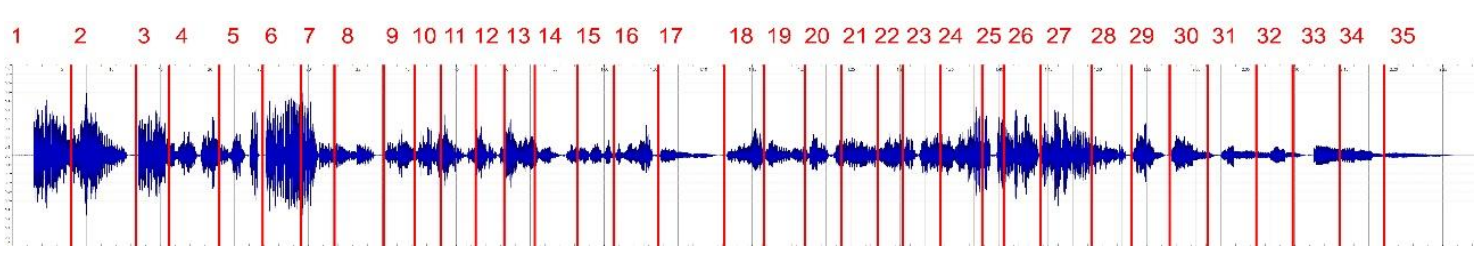

Figura 35: gráfico gravação 5 com barras de compasso

Pela oscilação do desenho criado pelo software, pode-se notar que a intérprete da gravação 5 usou bastante vibrato. No final do compasso 1, há um pequeno diminuendo e a dinâmica volta a fica igual a inicial no compasso 2. A dinâmica do compasso 3 é praticamente igual à do início e o compasso 4 tem a dinâmica mais suave, seguindo o piano marcado. Porém, o crescendo no início do compasso 4 não acontece. $O$ final do compasso 5 já é feito com uma dinâmica mais intensa e no compasso 6 ela fica ainda mais intensa, seguindo o crescendo marcado na parte. No compasso 7 há um decrescendo e no compasso 8 está marcado piano. $O$ decrescendo, nessa gravação, quase não acontece. $O$ que parece acontecer é um piano súbito no meio do compasso 7 , e a dinâmica se mantém até o compasso 8 .

Nos compassos 9, 10 e 11, é possível ver que a intérprete fez o crescendo marcado no final no compasso 10 e o decrescendo no final do compasso 11. No final do compasso 12 há um crescendo e o compasso 13 está marcado com mezzoforte. A dinâmica que aparece no compasso 13 não é muito diferente da dinâmica usada pela intérprete nos compassos 10, 11 e 12, que estão marcados com piano. No final do compasso 13 há um decrescendo e o compasso 14 está 
marcado com piano. Novamente, o que aparenta é que houve uma mudança brusca na dinâmica, e não um decrescendo. $\mathrm{O}$ crescendo do final do compasso 16 acontece, mas o compasso 17 já se inicia numa dinâmica mais suave. No compasso 18, a intérprete seguiu o crescendo marcado, seguido do piano no início do compasso 19.

A dinâmica se mantém mais ou menos constante nos compassos 21, 22, 23 e 24 e no compasso 25, onde há um mezzoforte marcado no fim do compasso, ela aumenta bruscamente. Não há nenhum crescendo marcado antes desse mezzoforte, e pode-se ver que a intérprete da gravação 5 escolheu fazer dele uma surpresa. No compasso 26 , há um crescendo marcado, mas ele praticamente não acontece. O decrescendo do compasso 28 é visível. Pode-se notar que a dinâmica desse trecho é menos intensa que a dinâmica do início da peça, mesmo estando as duas marcadas com mezzoforte.

Nos compassos 29 e 30, é possível ver a oscilação da dinâmica, seguindo os crescendos e decrescendos que estão marcados. No compasso 33, a intensidade da dinâmica aumenta um pouco, que é onde há um marcato na nota longa. Pode-se ver que no compasso 34 , a intérprete escolheu fazer apenas uma pequena ênfase, quase não alterando a dinâmica, que segue em diminuendo até o final da peça.

Analisadas todas as gravações individualmente, a seguir elas serão analisadas em relação uma com a outra. Para facilitar a visualização, os gráficos foram divididos em trechos. 
Trecho 01:

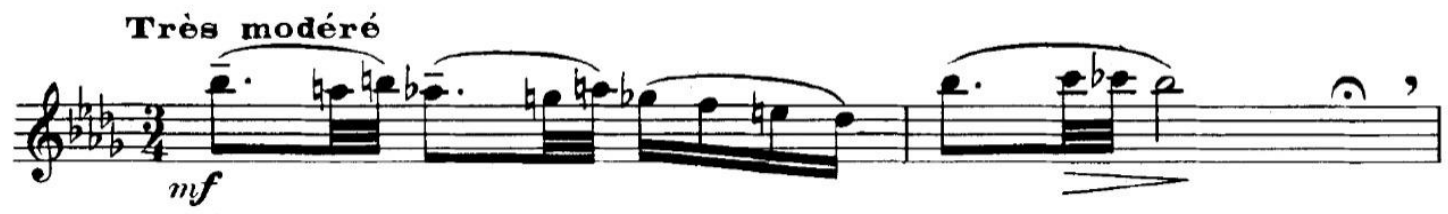

Gravação 1

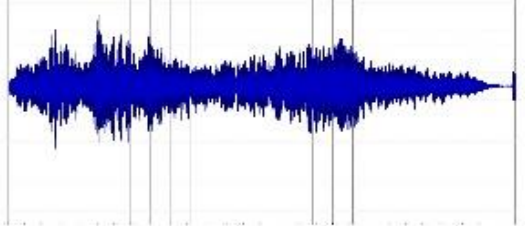

Gravação 2

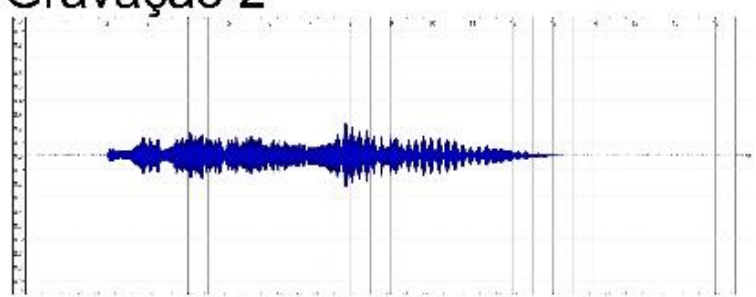

Gravação 3

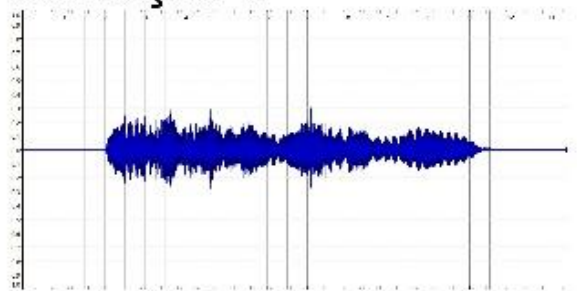

Gravação 4

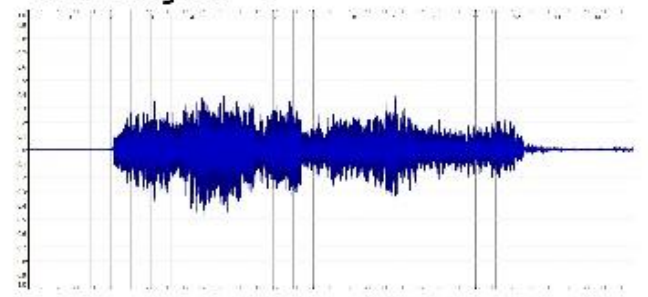

Gravação 5

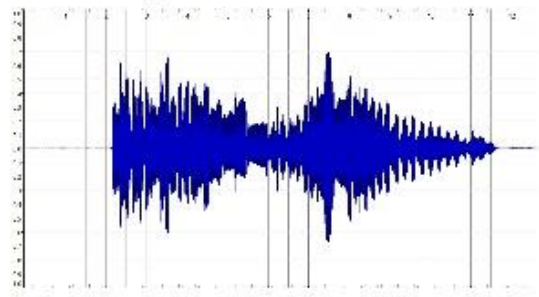

Figura 36: partitura e gráficos compassos 1 e 2 
Pelos gráficos pode-se ver que cada intérprete fez uma amplitude de dinâmica única no início da peça. As gravações 1, 2 e 4 se iniciam com a dinâmica um pouco mais suave e depois aumentam, enquanto as gravações $3 \mathrm{e}$ 5 mantém a dinâmica estável até a metade desse trecho, e depois têm um aumento na intensidade do som. Também é visível que a gravação 5 é a que tem mais vibrato e a gravação 2 inicia o trecho com um vibrato mais sutil.

Todos os intérpretes fizeram o decrescendo marcado. Os intérpretes das gravações 2 e 4 foram os que fizeram a fermata mais longa. 
Trecho 02:

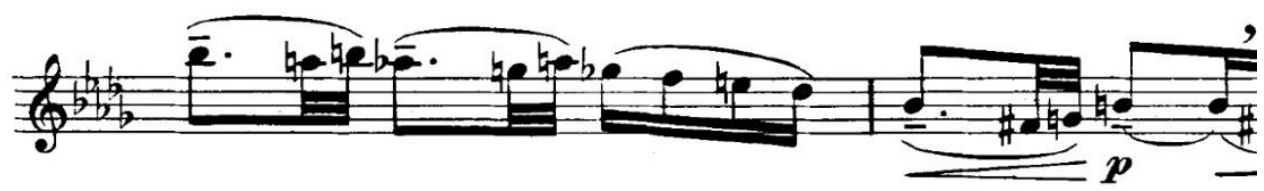

Gravação 1

Gravação 2

Gravação 3

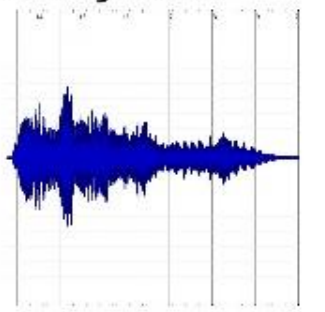

Gravação 4

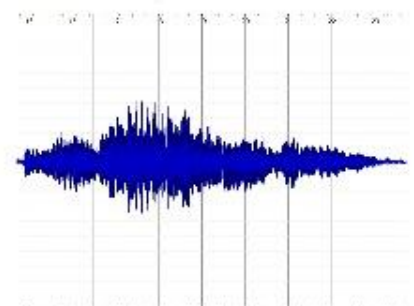

Gravação 5

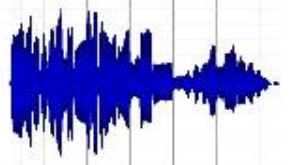

Figura 37: partitura e gráficos compassos 3 e 4 
Em relação ao trecho anterior, todos os intérpretes fizeram esse trecho com a dinâmica mais suave. Apesar de não haver indicação de dinâmica, é possível concluir que os intérpretes escolheram fazer esse trecho mais suave pois ele é repetição do tema inicial.

Pode-se notar que as gravações 1, 3, 4 e 5 iniciaram esse trecho com uma dinâmica mais intensa e depois diminuíram, apesar de não haver nenhuma marcação de dinâmica depois do mezzoforte inicial e de ter um crescendo marcado no segundo compasso desse trecho. Nas gravações 2 e 3, vê-se que os intérpretes fizeram, no final do trecho, o crescendo seguido de piano. Mas, na gravação 3 , esse crescendo surge de uma dinâmica mais suave, que não está marcada. 
Trecho 03:

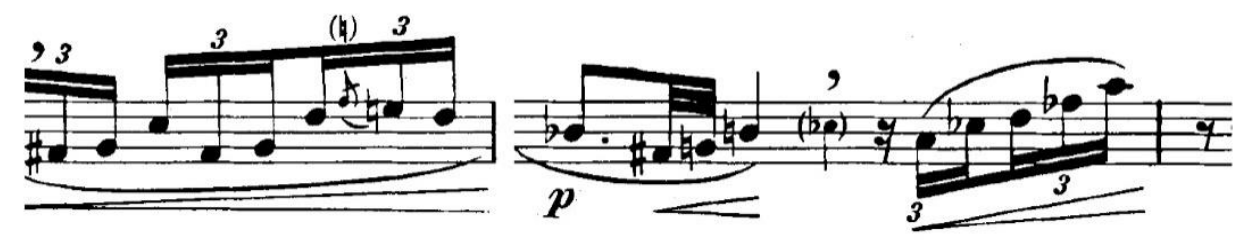

Gravação 1

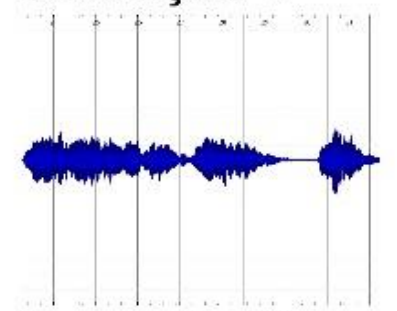

Gravação 2

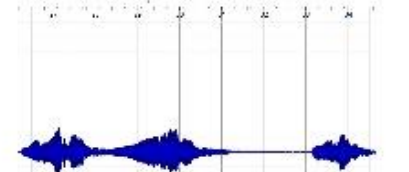

Gravação 3

Gravação 4

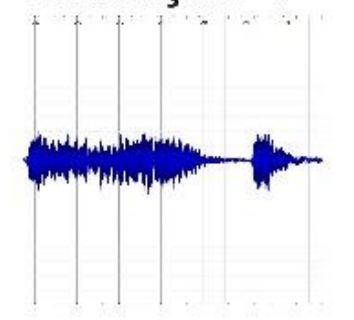

\section{Gravação 5}

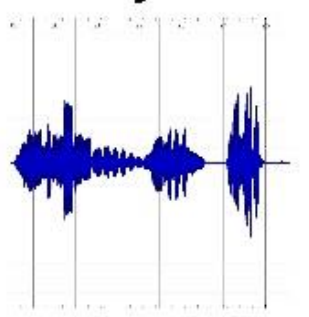

Figura 38: partitura e gráficos compassos 4 e 5 
Nesse trecho, todas as gravações seguiram as dinâmicas indicadas na partitura. A gravação 2 continua tendo a dinâmica mais suave entre todas as gravações. Pode-se ver que o intérprete da gravação 04 foi o que mais usou vibrato nesse trecho e a gravação 05 foi a que mais teve diferença na amplitude da dinâmica. Todos os intérpretes esperaram um momento em silêncio na marcação da fermata. Antes da fermata há um crescendo marcado, mas é possível notar que houve um diminuendo nessa nota em todas as gravações. Talvez tenha sido a finalização da nota (si natural) que causou esse desenho nos gráficos. Pode-se pensar, então, num momento de escolha de interpretação, em cortar essa nota em pleno crescendo, em vez que finalizá-la, fazendo assim um crescendo mais constante durante esse trecho. 
Trecho 04:

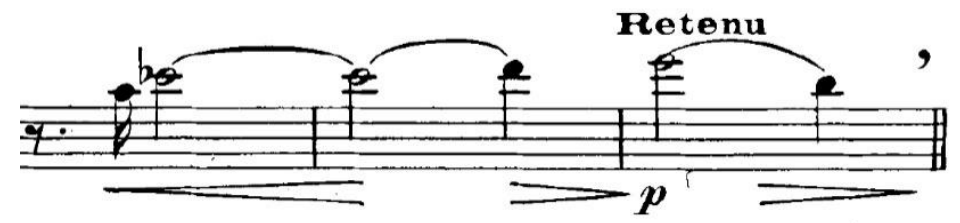

Gravação 1

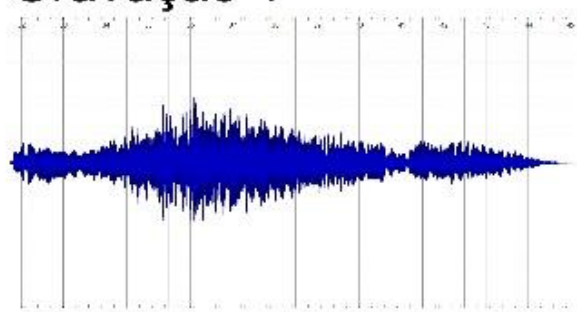

Gravação 2

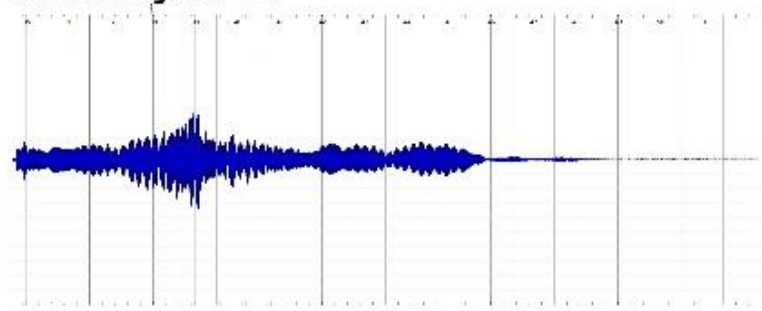

Gravação 3

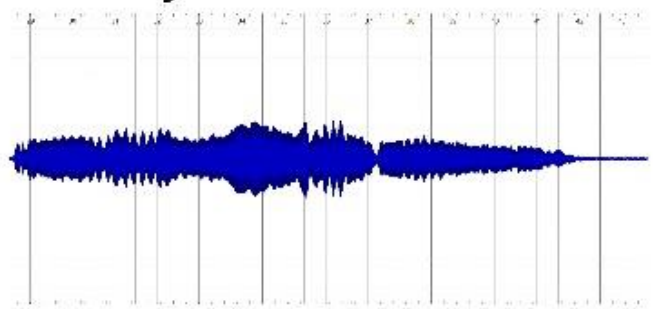

Gravação 4

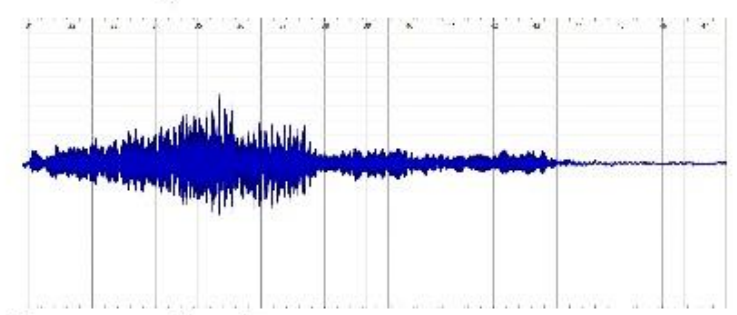

\section{Gravação 5}

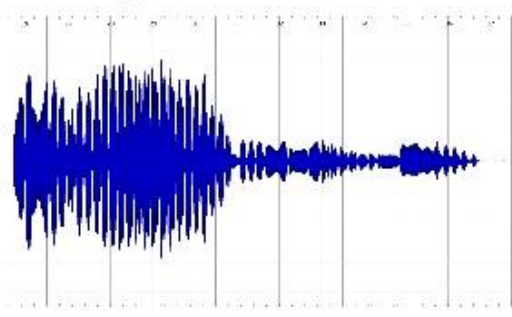

Figura 39: partitura e gráficos compassos 6 a 8 
É possível observar o crescendo e o decrescendo desse trecho em todas as gravações. Apenas a gravação 05 faz o início do trecho com a dinâmica um pouco mais intensa, decresce, volta a crescer e novamente decresce. A gravação 5 também é a que tem mais diferença entre a dinâmica do início do trecho para a do fim do trecho, onde está marcado piano. E também é a que possui o vibrato mais intenso. No gráfico da gravação 1, é possível ver com clareza o crescendo, o decrescendo e o piano. No gráfico da gravação 2 também é possível visualizar todas as nuances de dinâmica indicadas na partitura, porém, a dinâmica da gravação 2 é a mais suave entre todas as gravações. No gráfico da gravação 3 , vê-se também as mudanças de dinâmica, mas não são tão intensas quanto às outras gravações. No gráfico da gravação 4 , pode-se ver que houve uma diminuição da dinâmica com a chegada do piano marcado na parte. 
Trecho 05:

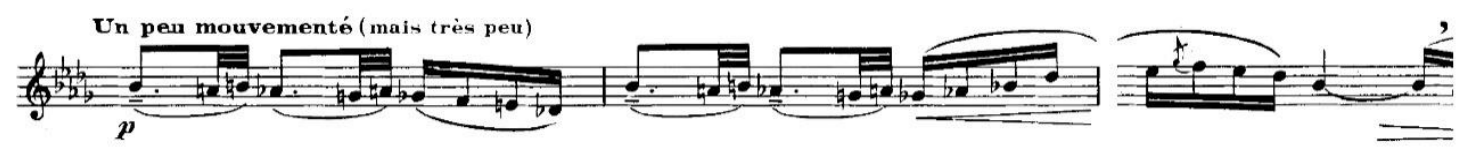

Gravação 1

Gravação 2

Gravação 3

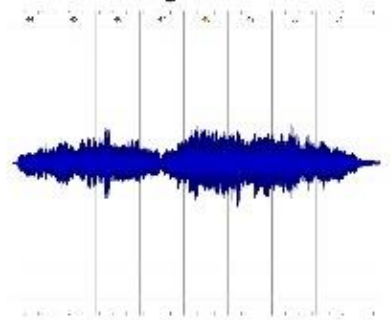

Gravação 4

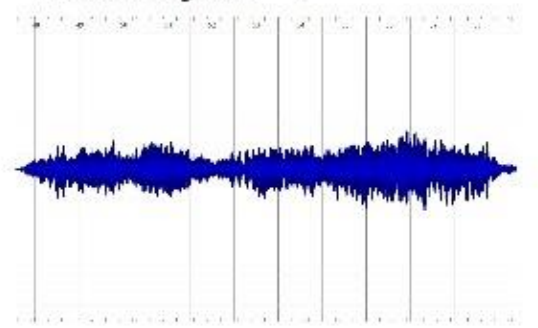

Gravação 5

Figura 40: partitura e gráficos compassos 9 a 11 
A gravação 2 segue tendo a dinâmica mais suave entre todas as gravações. Nesse trecho, há um piano marcado no início e um crescendo seguido de decrescendo no final. Nos gráficos das gravações 2, 3 e 4, essa mudança de dinâmica é visível, apesar de cada uma ter sua amplitude de dinâmica particular. A gravação 1 se mantém na mesma dinâmica no trecho todo, fazendo apenas o decrescendo do final, e não o crescendo anterior. A gravação 5 tem mudanças de dinâmica no início do trecho, mas no fim pode-se ver 0 crescendo e o decrescendo marcados. 
Trecho 06:

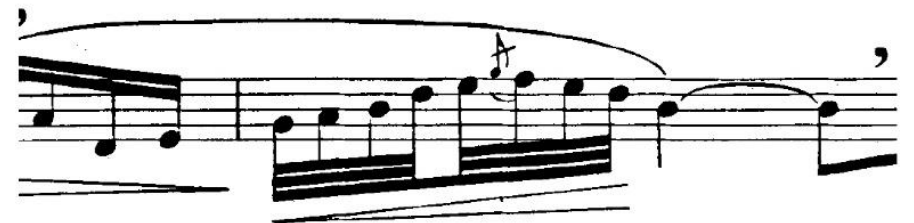

Gravação 1

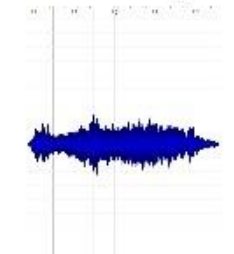

Gravação 2

Gravação 3

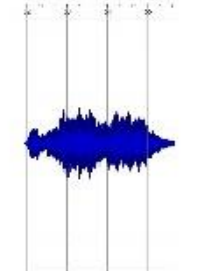

Gravação 4

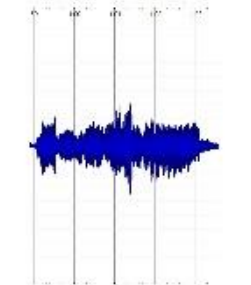

Gravação 5

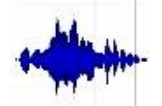

Figura 41: partitura e gráficos compassos 11 e 12 
Os gráficos, nesse trecho, quase não têm semelhança entre si. Além de cada uma ter uma amplitude particular de dinâmica, elas se diferenciam em relação aos crescendos e decrescendos. A gravação 01 faz um pequeno decrescendo no início, depois um pequeno crescendo e mantem a dinâmica estável. A gravação 02 tem um pequeno pico de dinâmica no meio do trecho e no final um pequeno crescendo. A gravação 03 tem um crescendo inicial e depois mantém a mesma dinâmica, com um pequeno decrescendo no final do trecho. $\mathrm{E}$ a gravação 5 começa o trecho numa dinâmica bem suave, cresce no meio, decresce e termina o trecho em dinâmica suave novamente.

Esse trecho é o que antecede o "pico" de dinâmica dessa sessão, e há um crescendo marcado no seu último compasso. Pode-se ver que o intérprete da gravação 2 escolheu não fazer a respiração indicada para dar continuidade ao crescendo e chegar no mezzoforte do próximo trecho. A diminuição de amplitude da dinâmica que vemos no final desse trecho pode, novamente, ser atribuída à finalização da nota longa final (si bemol). 
Trecho 07:
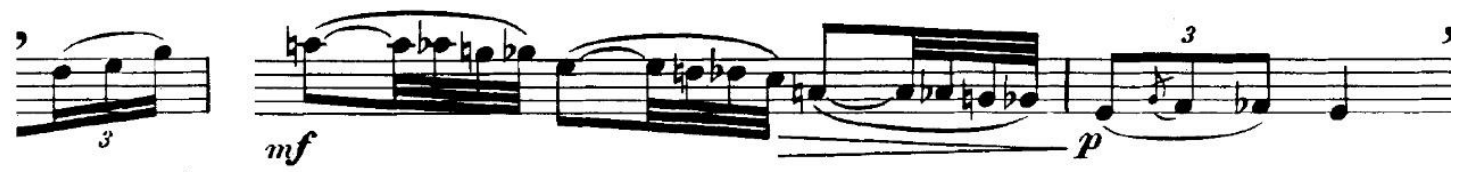

Gravação 1

Gravação 2

Gravação 3
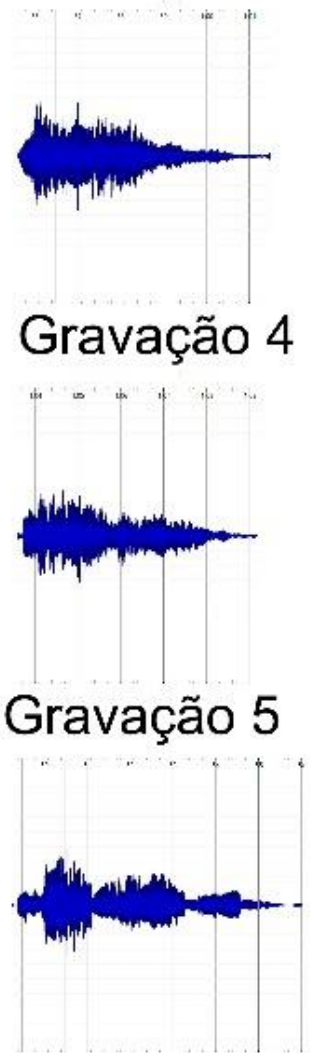

Figura 42: partitura e gráficos compassos 12 a 14 
Esse trecho é o ápice dessa sessão e nele os gráficos têm bastante semelhança entre si. Com exceção do gráfico da gravação 5 , todos começam com a dinâmica mais intensa e decrescem até o fim do trecho. A gravação 2 faz o decrescendo bem gradativamente ao longo do trecho. O decrescendo da gravação 3 também é gradativo, mas chega um pouco mais rápido ao piano que a gravação 2. A gravação parece ter 3 picos de dinâmica, em vez de um grande decrescendo como sugerido pela partitura. A gravação 5 , por sua vez, inicia 0 trecho em uma dinâmica mais suave, aumenta a intensidade bruscamente, diminui um pouco, em seguida diminui mais ainda, praticamente sem decrescendo, e, no final do trecho, faz ainda um pequeno crescendo que diminui rapidamente para uma dinâmica bem suave. 
Trecho 08:

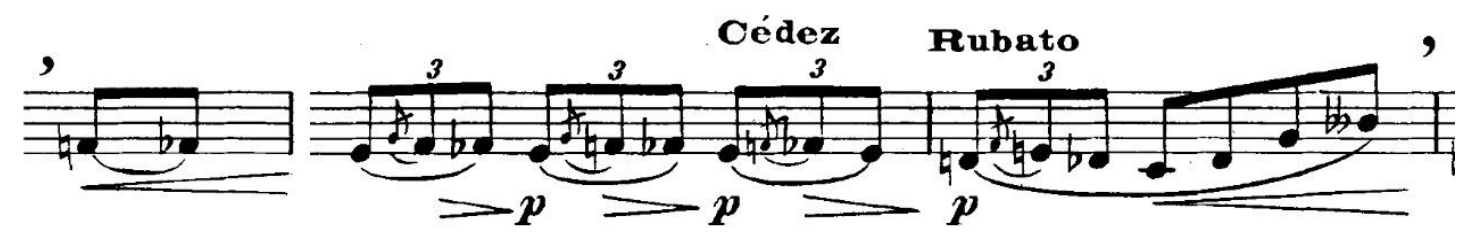

Gravação 1

Gravação 2

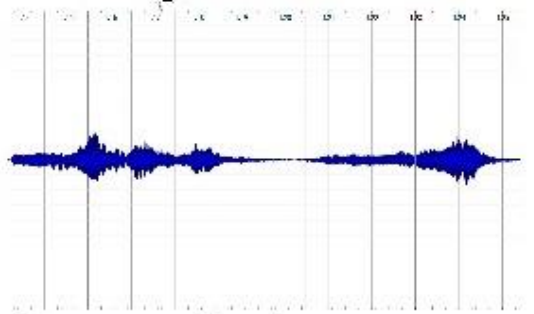

Gravação 3

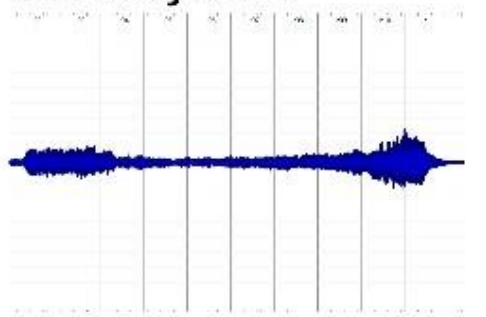

Gravação 4

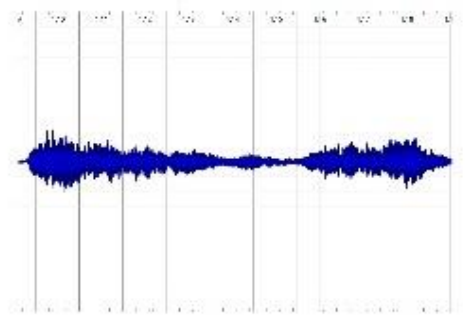

Gravação 5

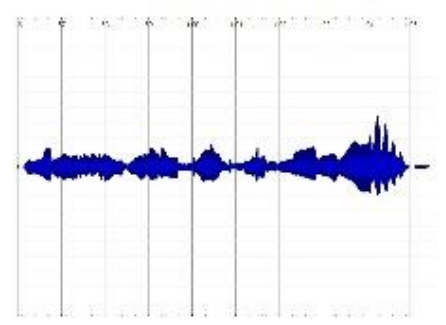

Figura 43: partitura e gráficos compassos 14 a 16 
As marcações de dinâmica desse trecho dão margem à diferentes interpretações. Considerando que a dinâmica marcada no início do primeiro compasso desse trecho (último compasso do trecho 07) é piano, e que há um crescendo, um decrescendo e outro piano, pode-se concluir que se deve voltar a dinâmica na mesma amplitude do início do trecho. Mas, a próxima marcação é outro decrescendo, dessa vez a partir do piano, e no final do decrescendo há outro piano. Pelos gráficos pode-se ver que o intérprete da gravação 2, após fazer o crescendo e o decrescendo do começo do trecho, aumentou um pouco a dinâmica antes dos próximos crescendos e chegou ao piano. A gravação 5 fez algo parecido com isso. A gravação 4, por sua vez, fez um grande decrescendo enquanto a $3 \mathrm{fez}$ um decrescendo no início do trecho e manteve o piano. A gravação 1 praticamente não mudou a dinâmica no trecho todo. $O$ crescendo do final do trecho é visível nas gravações 2, 3, 4 e 5, sendo a 5 a que possui mais vibrato. 
Trecho 09:

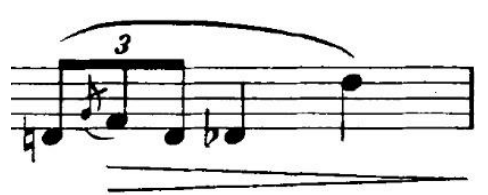

Gravação 1

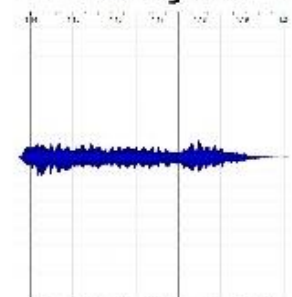

Gravação 2
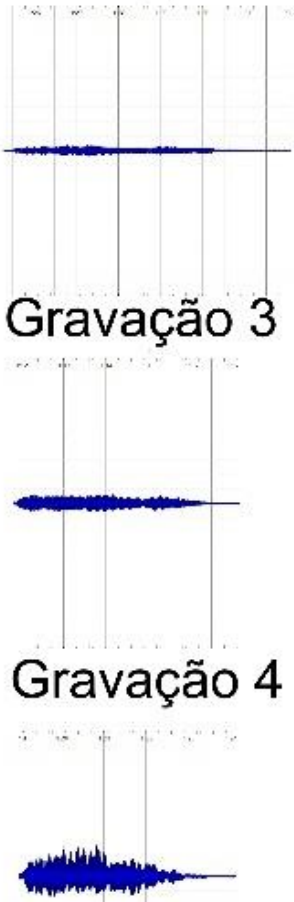

\section{Gravação 5}

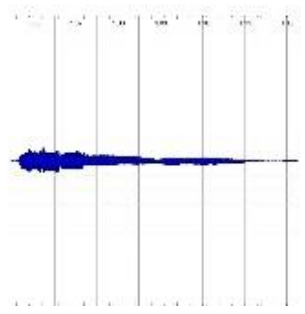

Figura 44: partitura e gráficos compasso 17 
Nesse trecho, a gravação 4 é a que tem a dinâmica mais intensa. A gravação 2 quase não faz o decrescendo marcado pois já está desde o início com uma dinâmica muito suave. A gravação 5 é a que tem mais visível no gráfico o decrescendo marcado no trecho. As gravações 1 e 3 têm o gráfico bem semelhante nesse trecho, em ambas pode-se ver um pequeno aumento da dinâmica na mudança de oitava do Ré Bemol. Apesar de não haver fermata no final desse trecho, todos os intérpretes fizeram um cedendo e esperaram um tempo em silêncio, deixando a nota final (re bemol) morrer e esperando um pouco para retomar a música. 
Trecho 10:

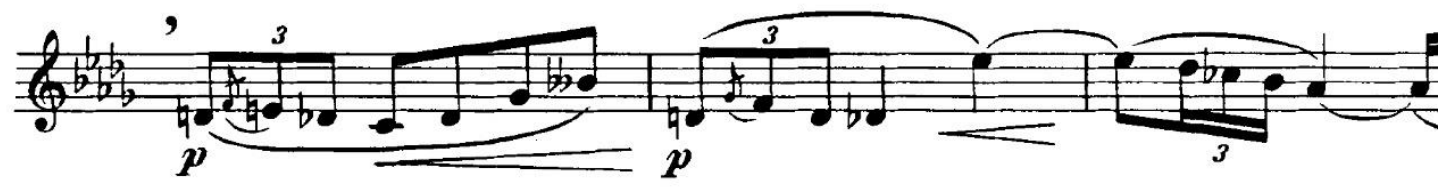

Gravação 1

Gravação 2

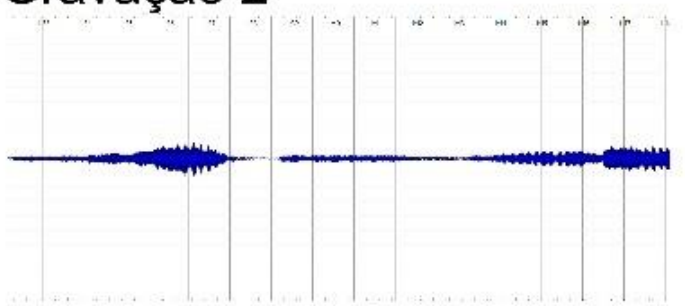

Gravação 3

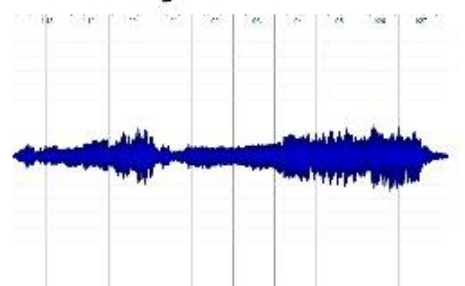

Gravação 4

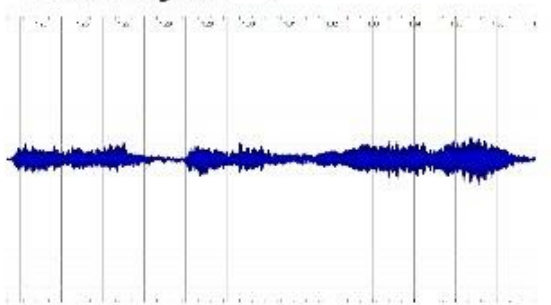

Gravação 5

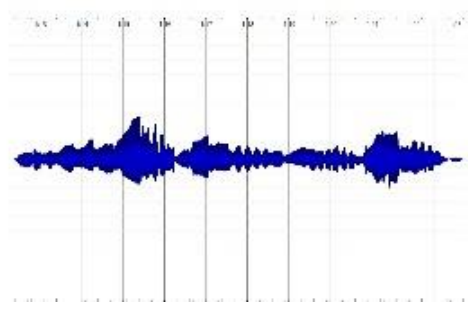

Figura 45: partitura e gráficos compasso 18 a 20 
Apesar da amplitude da dinâmica ser diferente em cada gráfico, é possível notar que nesse trecho todos os intérpretes seguiram as indicações da partitura. Apenas o intérprete da gravação 4, no início do trecho, não faz o crescendo indicado, e sim mantém a dinâmica na mesma amplitude. Na gravação 5, o crescendo do segundo compasso do trecho acontece mais tardiamente. A gravação 2 continua sendo a que tem a dinâmica mais suave entre todas as gravações. Pelo gráfico da gravação 1 , pode-se ver que houve uma interrupção no crescendo do final do trecho, talvez indicando que o intérprete respirou nesse momento. 
Trecho 11:

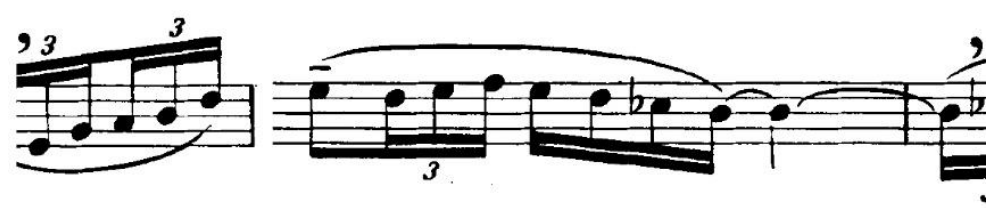

Gravação 1

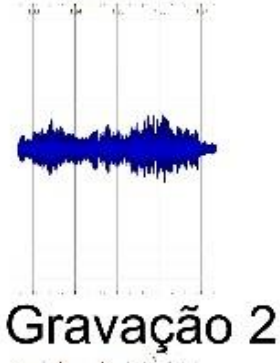

Gravação 3
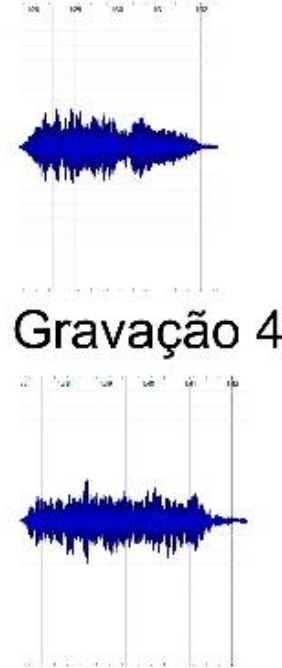

Gravação 5

Figura 46: partitura e gráficos compassos 20 e 21 
Esse trecho não possui indicações de dinâmica escritas na partitura. Porém, pode-se ver que as gravações 3 e 4 fizeram um decrescendo na nota final, sendo o decrescendo da gravação 3 mais longo que o da gravação 4. A gravação 5 manteve a dinâmica praticamente constante em todo o trecho. As gravações 1 e 2 tiveram pequenas variações de dinâmica ao longo do trecho. 
Trecho 12:

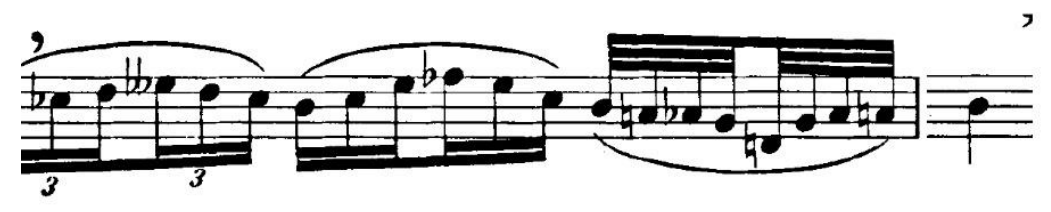

Gravação 1

Gravação 2

Gravação 3

Gravação 4

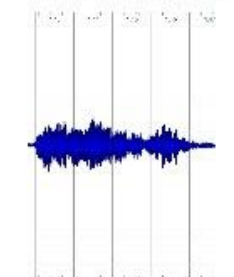

Gravação 5

Figura 47: partitura e gráficos compassos 22 e 23 
Esse trecho não possui grandes variações de dinâmica, apenas o gráfico da gravação 3 mostra algumas mudanças de intensidade. Nos gráficos das gravações 4 e 5 pode-se ver uma diminuição no som um pouco antes do final do trecho, mostrando talvez um final mais acentuado para a ligadura que termina antes da última nota do trecho. 
Trecho 13:

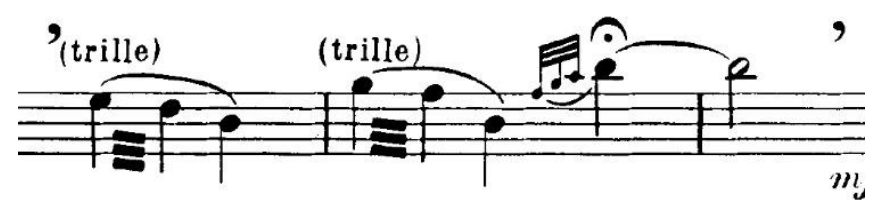

\section{Gravação 1}

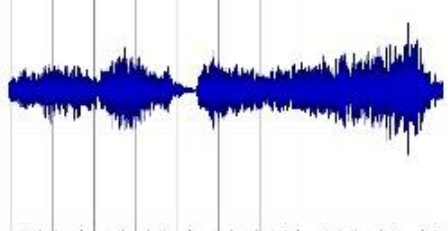

Gravação 2
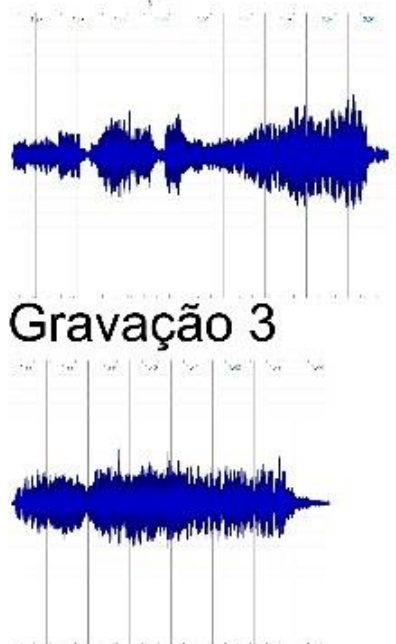

Gravação 4

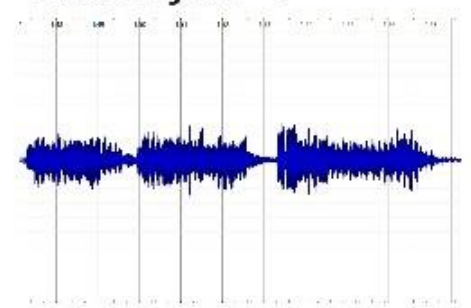

\section{Gravação 5}

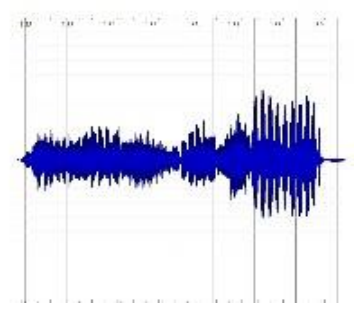

Figura 48: partitura e gráficos compassos 23 a 25 
Esse trecho antecede a volta do tema, que está marcado com mezzoforte. Pode-se ver que houve diferentes escolhas interpretativas entre os intérpretes que estão sendo analisados aqui. $O$ intérprete da gravação $1 \mathrm{fez}$ um pequeno corte antes da nota longa final (e suas apojaturas), talvez para respirar ou mesmo para dividir as ideias musicais. E, na nota longa, ele fez um crescendo.

O intérprete da gravação 2, por sua vez, fez pequenos cortes entre as 3 ligaduras marcadas nesse trecho. A primeira teve dinâmica mais suave, a segunda um pouco mais intensa e na nota longa, ele fez um rápido decrescendo, seguido de um grande crescendo.

Na gravação 3 não houve interrupção do som entre as ligaduras e não houve aumento nem diminuição da dinâmica, apenas no final do trecho o intérprete fez um decrescendo para finalizar a nota longa.

O gráfico da gravação 4 mostra que o intérprete escolheu, assim como o intérprete da gravação 2, separar as ligaduras cortando o som. Mas, por sua vez, esse intérprete não faz um crescendo na nota longa final, e sim a mantém na mesma intensidade até sua finalização.

O intérprete da gravação 5 não faz cesuras entre as ligaduras do trecho, e na nota longa final, aumenta a intensidade da dinâmica e faz um grande vibrato. 
Trecho 14:

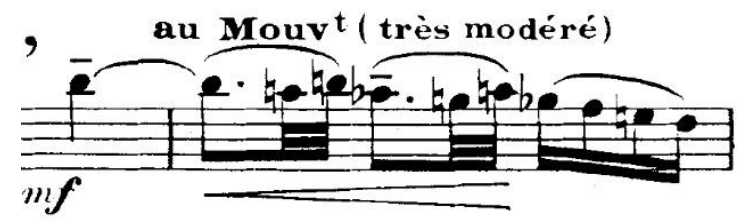

Gravação 1

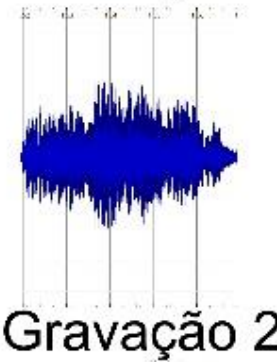

Gravação 3

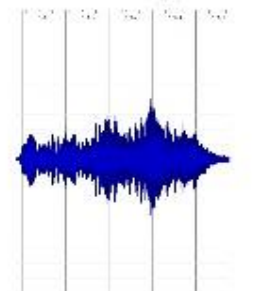

Gravação 4
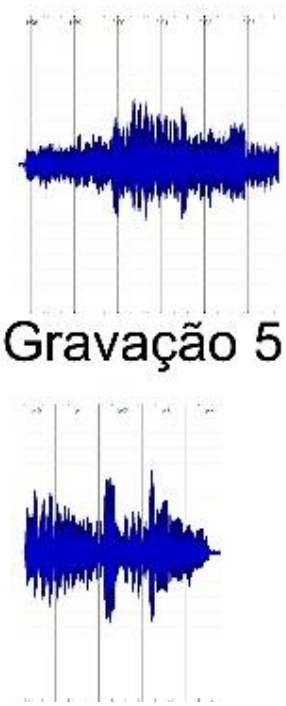

Figura 49: partitura e gráficos compassos 25 e 26 
Apesar de haver um crescendo marcado nesse trecho, vemos que apenas o intérprete da gravação 4 o fez. Os intérpretes das gravações 1 e 2 escolheram manter a dinâmica do trecho toda mais intensa. Na gravação 3, o intérprete faz um pequeno crescendo seguido de decrescendo. No gráfico 4 pode-se ver que houve um crescendo no início do trecho e no gráfico da gravação 5 vemos uma diminuição da dinâmica no meio do trecho. Esse trecho é a volta do tema inicial e pode-se ver que cada intérprete escolheu uma maneira diferente de reapresentá-lo, mesmo não indo de encontro com o que está escrito na partitura. 
Trecho 15:

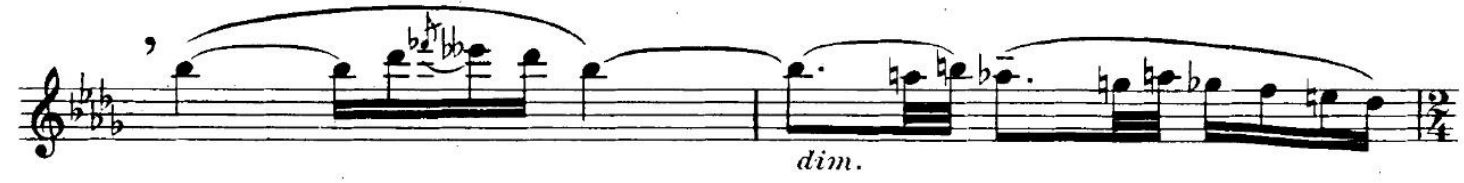

Gravação 1

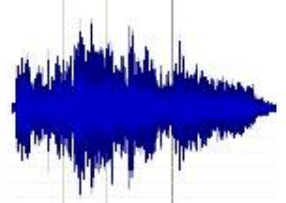

Gravação 2

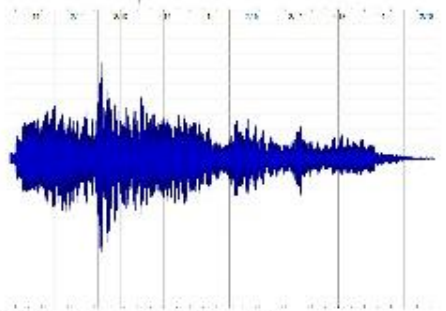

Gravação 3
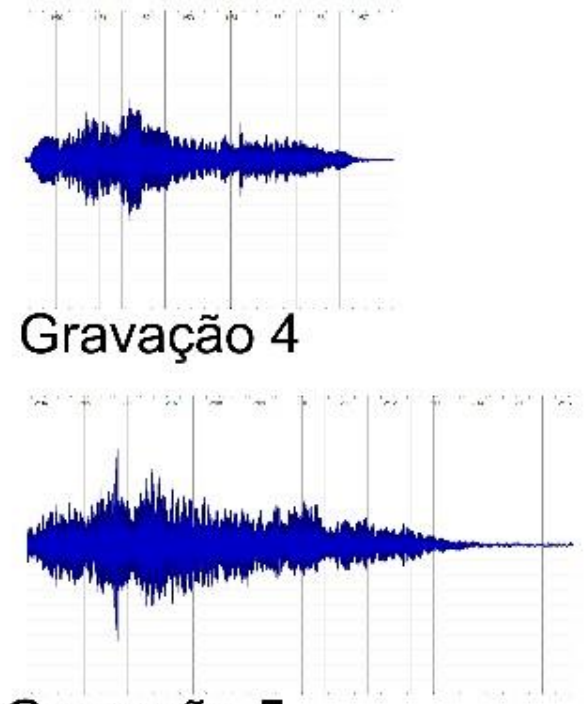

Gravação 5

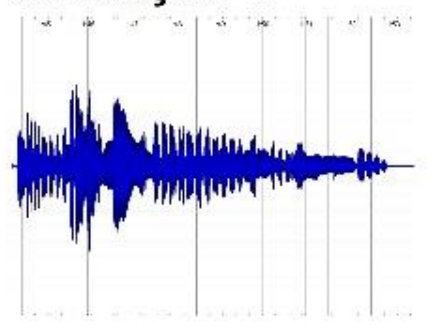

Figura 50: partitura e gráficos compassos 27 e 28 
Esse trecho é a transição entre o momento mais intenso da peça para seus momentos finais. Há um diminuendo marcado e todos os intérpretes analisados aqui o seguiram. É possível ver também que durante o início do trecho, os intérpretes usavam mais vibrato e a intensidade do vibrato diminuiu, assim como a dinâmica. Em todos os gráficos também é possível ver que a intensidade da dinâmica aumentou um pouco nas notas mais agudas do trecho, o que é esperado. As gravações 2 e 4 mantiveram a dinâmica inicial quase no mesmo patamar durante o primeiro compasso. A gravação 5 tem picos de dinâmica e tem o vibrato bem marcado. 
Trecho 16:
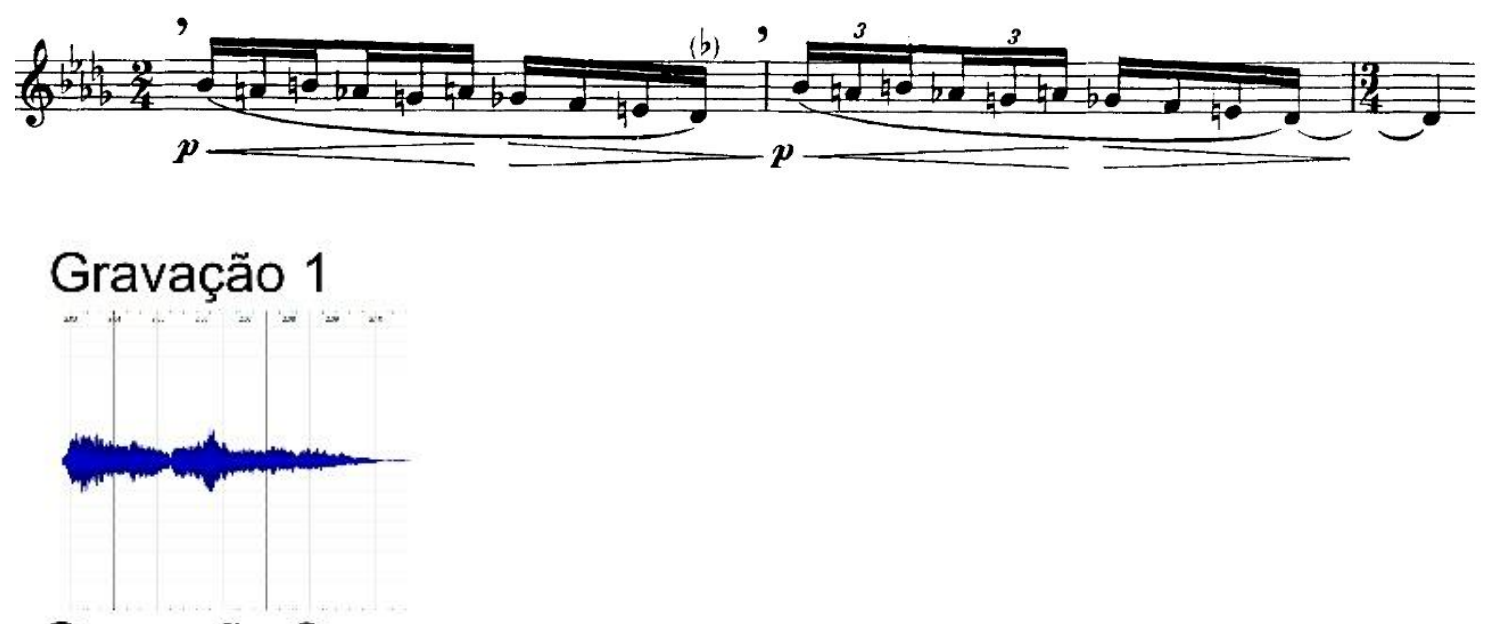

Gravação 2

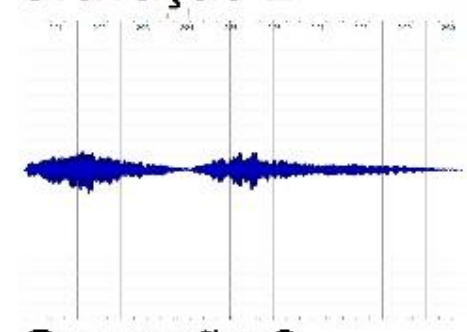

Gravação 3

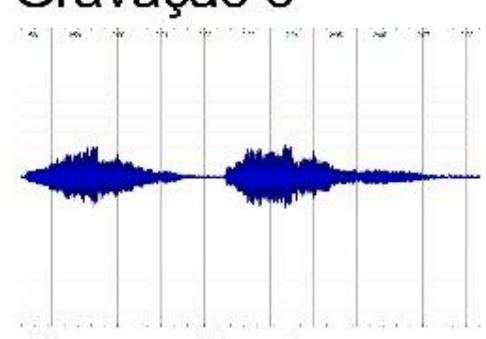

Gravação 4

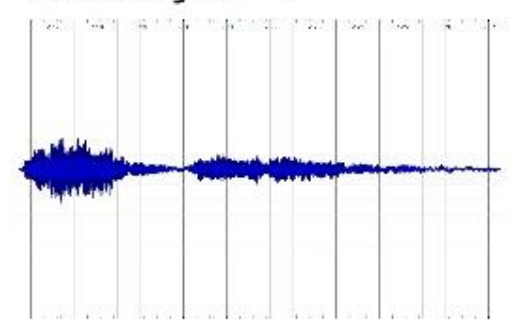

Gravação 5

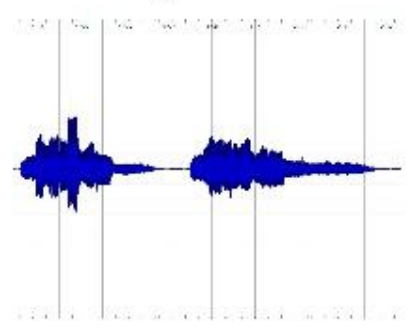

Figura 51: partitura e gráficos compassos 29 e 30

110 
Os dois compassos desse trecho são exatamente iguais: notas, ritmo, ligaduras e indicação de dinâmica. No entanto, é esperado que os intérpretes façam algo de diferente no segundo compasso, justamente para a música não ficar repetitiva. O intérprete da gravação 1 fez, no segundo compasso, uma dinâmica diferente do primeiro: o decrescendo foi mais intenso no segundo compasso e o crescendo também foi mais aparente, visto que no primeiro compasso o crescendo quase não acontece. Pelo gráfico, vemos que o intérprete da gravação 2 fez o segundo compasso bem parecido com o primeiro em questão de dinâmica, porém, com intensidade um pouco menor. Já o intérprete da gravação 3 , além de esperar um pouco mais em silêncio entre um compasso e outro, fez o segundo compasso com a dinâmica diferente do primeiro: no primeiro ele faz o crescendo e o decrescendo marcados, mas, no segundo, o crescendo é feito mais rápido, o decrescendo é mais lento e há uma diminuição da dinâmica no fim do trecho. O intérprete da gravação 4 faz o segundo compasso bem mais piano que o primeiro, e, também, quase sem variação de dinâmica. É possível ver que o segundo compasso se alonga mais que o primeiro. Na gravação 5 , ambos compassos são feitos de maneira parecida em relação à dinâmica, e há um momento de silencio entre um e outro. 
Trecho 17:

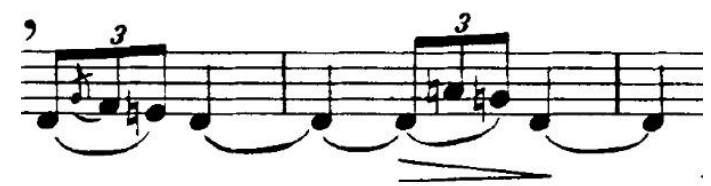

Gravação 1

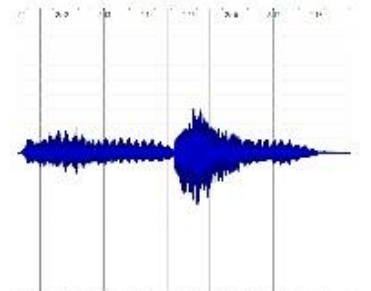

Gravação 2

Gravação 3

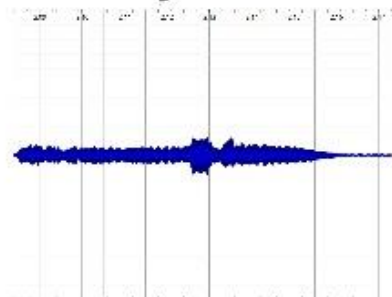

Gravação 4
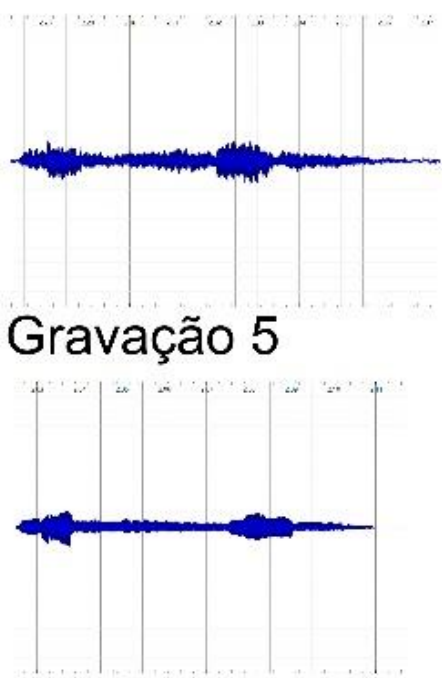

Figura 52: partitura e gráficos compassos 31 e 32 
Na gravação 1, o intérprete aumentou a dinâmica antes do decrescendo que está marcado na partitura. Entre os intérpretes analisados aqui, este foi o único que fez essa diferença tão grande de dinâmica nesse trecho. Em todos os gráficos é possível ver um pequeno aumento na dinâmica no momento em que se toca o La bemol. Talvez, a dinâmica já esteja muito piano e não tenha como fazer mais decrescendo ainda, por isso os intérpretes fizeram um pequeno aumento na dinâmica para depois decrescer novamente. As gravações 4 e 5 decrescem logo no início do trecho, onde não há nenhum decrescendo marcado, mas há uma nota longa. 
Trecho 18:

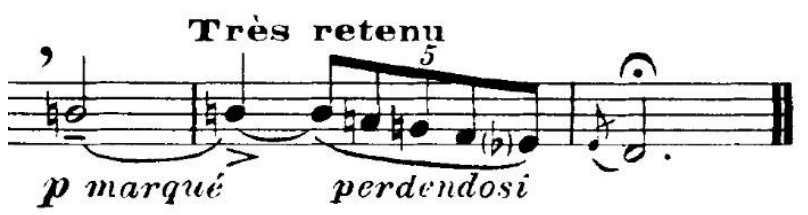

Gravação 1

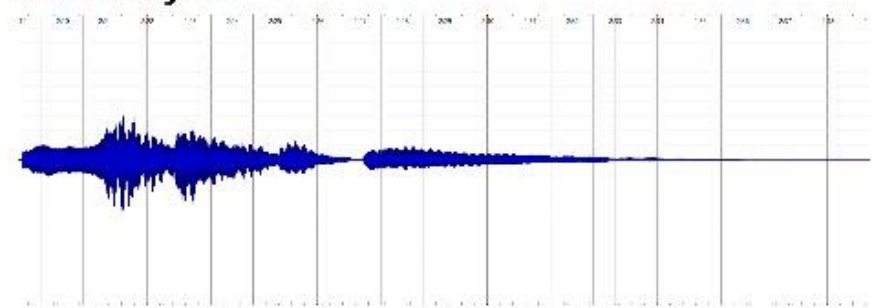

Gravação 2

\section{Gravação 3}

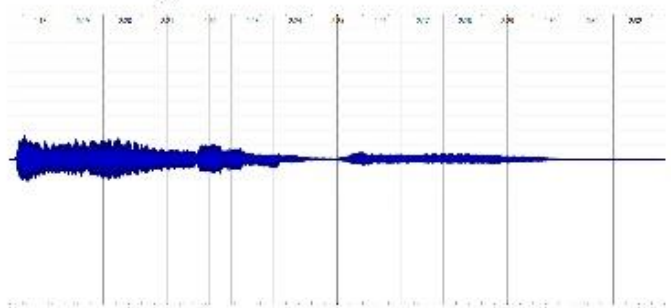

Gravação 4

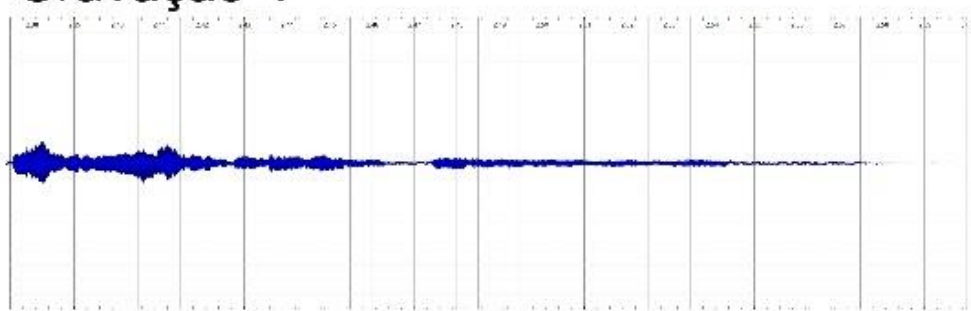

Gravação 5

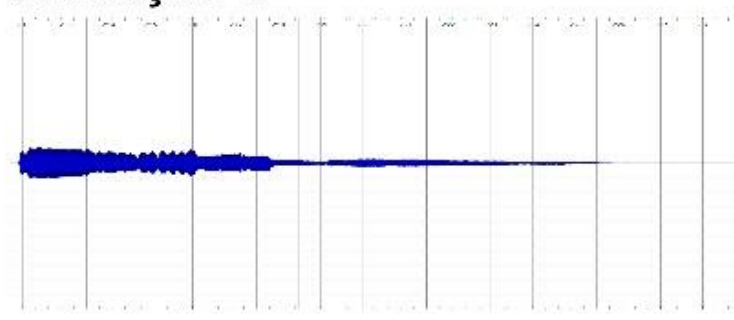

Figura 53: partitura e gráficos compassos 33 a 35 
Esse é o trecho final da música, seus últimos compassos. A primeira nota do trecho é um Si natural, piano, com um marcato e ainda um marquè. A nota segue ligada até o próximo compasso, nele há o acento que no manuscrito de Bruxelas é, na verdade, um decrescendo. Pode-se ver que na gravação 1, o intérprete fez o acento na nota ligada com bastante intensidade. Na gravação 2, está tudo tão piano que quase não se vê diferença alguma de intensidade de dinâmica nesse trecho. $O$ intérprete da gravação 3 faz o acento da nota longa, mas menos "pontudo" que o primeiro intérprete, pois no gráfico vê-se mais uma "barriga" do que um pico nesse momento. Na gravação 4, também há acentuação na nota longa, a dinâmica volta à mesma intensidade do início do trecho. E na gravação 5 não há acentuação, apenas um decrescendo.

$\mathrm{Na}$ última nota, todos os intérpretes decrescem a dinâmica até chegar ao silencio. Não há mudanças de dinâmica na última nota. A gravação 1, entretanto, é a que inicia a nota final com dinâmica mais intensa. 


\section{Capítulo VIII - Quadro Comparativo entre as Gravações}

Dizer que o intérprete deveria criar a música do zero, como se nenhuma performance existisse anteriormente à sua, seria até perverso. (RINK, 2018).

As gravações são uma fonte extensa e de fácil acesso e mesmo sabendo que são geralmente resultado de vários takes, tornando-se "a representação de uma performance que, na realidade, nunca existiu." (COOK 2006, p. 14), a audição de várias interpretações da mesma obra, "é sempre muito válida. Além de adquirirmos referências, as gravações nos instigam a pesquisar e estudar novas possibilidades para interpretação." (D’ÁVILA s/d, p. 7).

Os intérpretes têm liberdade para criar diferentes maneiras de se interpretar uma peça e a personalidade e multiplicidade nas interpretações não são elementos negativos, pois, na verdade, revelam-se como índice de riqueza (ABDO, 2000).

Após todas as considerações feitas através dos gráficos de dinâmica e tempo e ainda dentro do campo da análise da performance, abaixo apresentamse outras comparações entre as gravações na busca de encontrar opções interpretativas variadas. Tais comparações foram feitas através da audição das gravações, comparação das performances com a partitura e entre si.

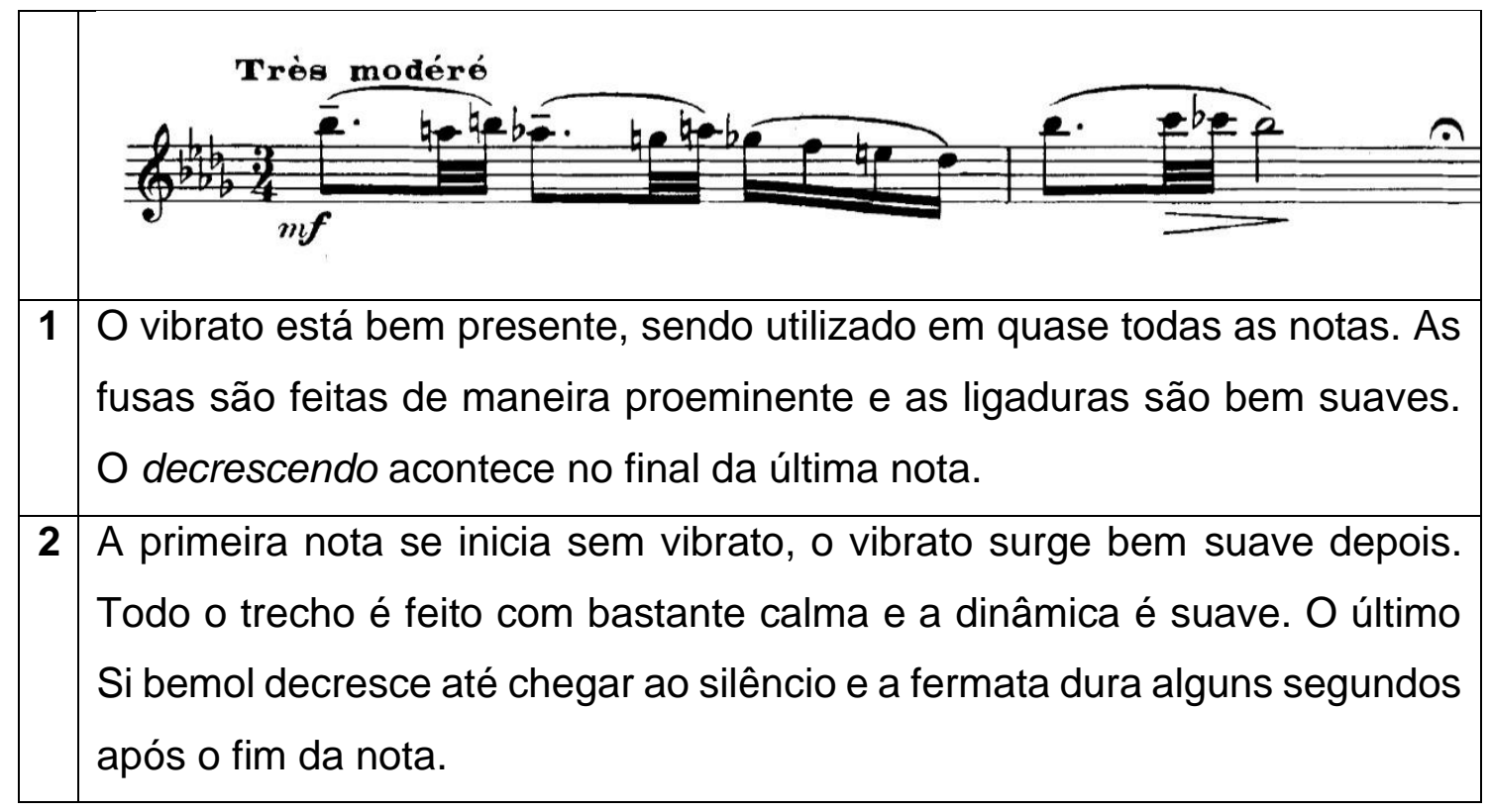


3 O Si bemol inicial e o La bemol seguinte são feitos com vibrato intenso. No segundo compasso, o vibrato fica mais suave, assim como a dinâmica. A última nota é feita quase sem vibrato, em dinâmica mais suave.

4 Todas as notas, inclusive as semicolcheias e fusas, têm um vibrato bem pronunciado. O Si bemol final apresenta um pequeno decrescendo, mas o vibrato segue até o corte da nota.

5 Há vibrato nas notas mais longas do trecho. A nota final é bem longa, o decrescendo acontece juntamente com a diminuição do vibrato e a nota decresce até o silêncio.

\begin{tabular}{|l|l|}
\hline 1 & $\begin{array}{l}\text { O vibrato continua presente. Na marcação de crescendo existe um } \\
\text { pequeno rallentando. O crescendo seguido de piano não acontece. O } \\
\text { mistério dessa parte é mostrado através do rallentando que o intérprete } \\
\text { criou. }\end{array}$ \\
\hline $\mathbf{2}$ & $\begin{array}{l}\text { A dinâmica aqui está um pouco mais intensa que o primeiro trecho. Há um } \\
\text { suave crescendo no primeiro compasso do trecho, culminando no Si bemol } \\
\text { que inicia o segundo compasso. O Si bequadro é feito em piano, seguindo } \\
\text { a sugestão do compositor do crescendo seguido de piano. }\end{array}$ \\
\hline $\mathbf{3}$ & $\begin{array}{l}\text { O vibrato continua muito presente, intenso e rápido. O piano marcado } \\
\text { acontece e o Si bequadro parece durar pouco. }\end{array}$ \\
\hline $\mathbf{4}$ & $\begin{array}{l}\text { Após um pequeno instante de silêncio, o trecho se inicia com a dinâmica } \\
\text { um pouco mais suave que o trecho anterior, mas o vibrato continua bem } \\
\text { presente. O piano marcado após o crescendo não acontece. }\end{array}$ \\
\hline $\mathbf{5}$ & $\begin{array}{l}\text { A dinâmica e o tempo mantem-se praticamente iguais, sendo essa frase } \\
\text { praticamente uma cópia da primeira. O piano marcado no Si bequadro não } \\
\text { acontece. }\end{array}$ \\
\hline
\end{tabular}



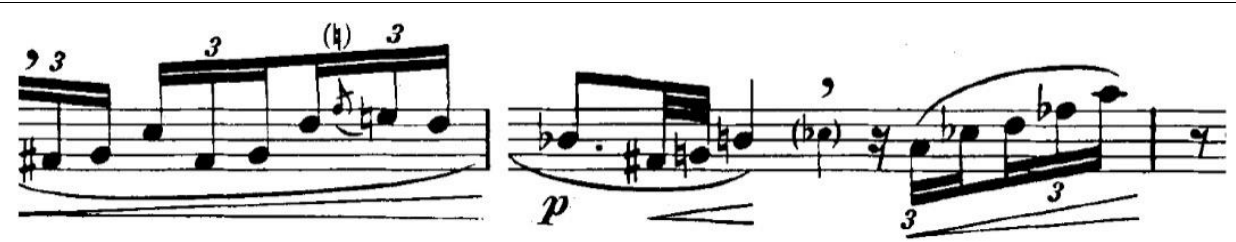

1 O piano não acontece, a dinâmica continua intensa. Há variações de tempo. O último Lá Bemol é feito quase num staccato.

2 A apojatura, o Mi bequadro e o Re são feitos num tempo mais lento e o Re já é feito em dinâmica piano. O Si bemol seguinte, onde há a marcação de piano, é feito numa dinâmica mais intensa e o Si bequadro seguinte, num piano.

3 No Re bemol que finaliza o primeiro compasso do trecho, já existe um decrescendo, para poder chegar no próximo compasso em piano. As tercinas de semicolcheias do final do compasso são feitas em andamento mais lento, bem pronunciadas.

4 Nas tercinas de semicolcheia, o intérprete acelera o tempo um pouco, voltando ao tempo inicial no Si bemol marcado com piano. O acelerando pode ter sido feito para enfatizar o crescendo marcado no início do trecho. O piano marcado no Si bemol não acontece, em vez disso há um aumento na dinâmica de todo o trecho.

5 Após a apojatura há uma redução no andamento e a dinâmica decresce um pouco para chegar no Si bemol marcado em piano.

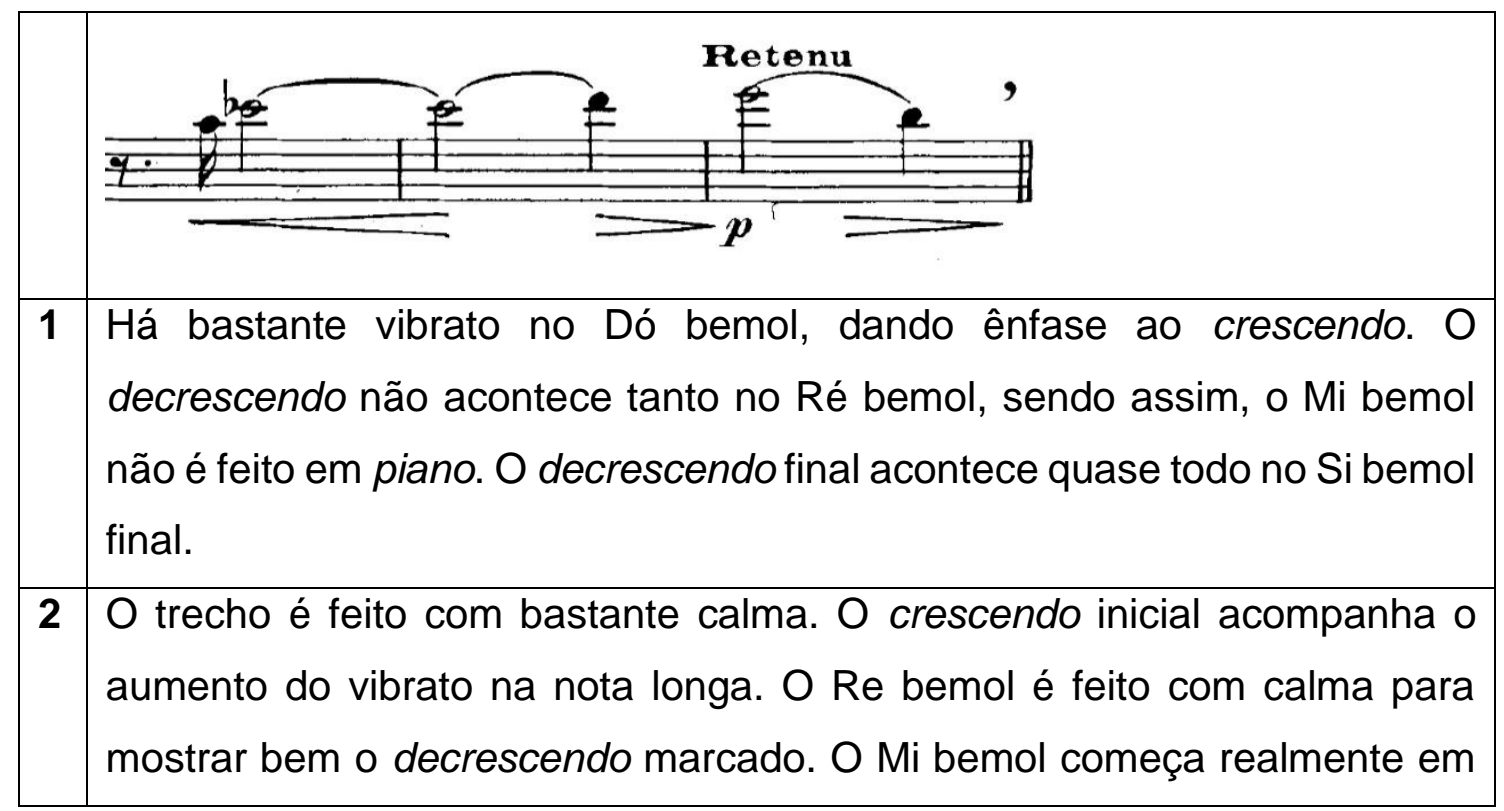




\begin{tabular}{|l|l|}
\hline 3 & $\begin{array}{l}\text { dinâmica piano e o Si bemol final já começa em dinâmica bem suave, } \\
\text { decrescendo até o silêncio. Há uma fermata no silêncio após o final da } \\
\text { última nota. } \\
\text { Antes desse trecho, há uma pequena pausa em silêncio. A dinâmica do Do } \\
\text { bequadro cresce, mas o vibrato não aumenta de intensidade. O } \\
\text { decrescendo marcado no Re bemol quase não acontece, pois ele já } \\
\text { aconteceu antes, no Do bemol. A dinâmica do Mi bemol se mantém como } \\
\text { a do Re bemol anterior, e no Si bemol, ela decresce. }\end{array}$ \\
\hline 4 & \begin{tabular}{l} 
O aumento da intensidade da dinâmica é acompanhado com o aumento \\
na intensidade do vibrato. No Re bemol, a dinâmica diminui e o vibrato \\
perde um pouco sua força, mas continua presente. O Mi bemol começa em \\
dinâmica realmente mais suave, e o decrescendo marcado no final do \\
trecho realmente acontece. \\
\hline 5
\end{tabular} $\begin{array}{l}\text { O crescendo na dinâmica acompanha um aumento do vibrato na primeira } \\
\text { nota longa. O Re bemol é feito quase sem vibrato e no Mi bemol o vibrato } \\
\text { retorna, mais lento, em concordância com a dinâmica mais suave. }\end{array}$ \\
\hline
\end{tabular}

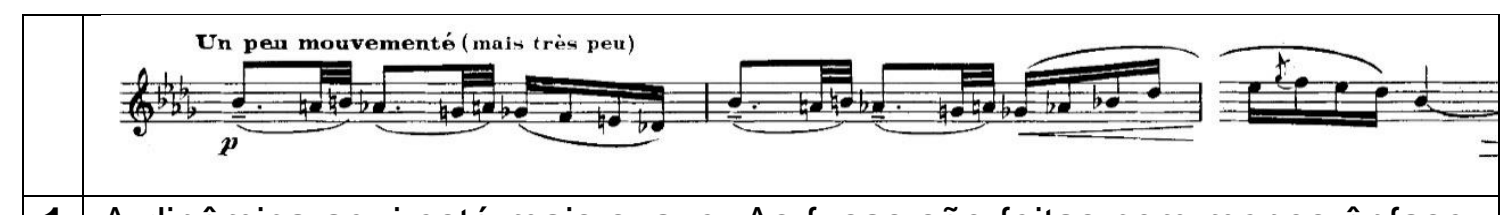

1 A dinâmica aqui está mais suave. As fusas são feitas com menos ênfase. Entre um compasso e outro existe um pequeno rubato. Na marcação de crescendo, há também um acelerando, indo de encontro à agitação criada pelas notas deste trecho.

2 A dinâmica é mais suave e o timbre mais escuro. Todo o trecho é feito com bastante calma, aparentemente o andamento está mais lento que o início da peça. Não há grandes variações de tempo.

3 No segundo compasso do trecho, o intérprete faz a dinâmica mais intensa que no primeiro, talvez buscando uma maneira de diferenciar esses dois compassos que são iguais no começo.

4 Há uma pausa em silêncio antes do início deste trecho. A dinâmica é mais suave, mas o vibrato ainda está presente. O tempo é um pouco mais lento. No segundo compasso do trecho, o intérprete faz a dinâmica ainda mais suave, o que enfatiza o crescendo marcado no final do compasso. 
5 A dinâmica não parece estar tão suave nesse trecho, porém é possível notar que o timbre está um pouco mais escuro.

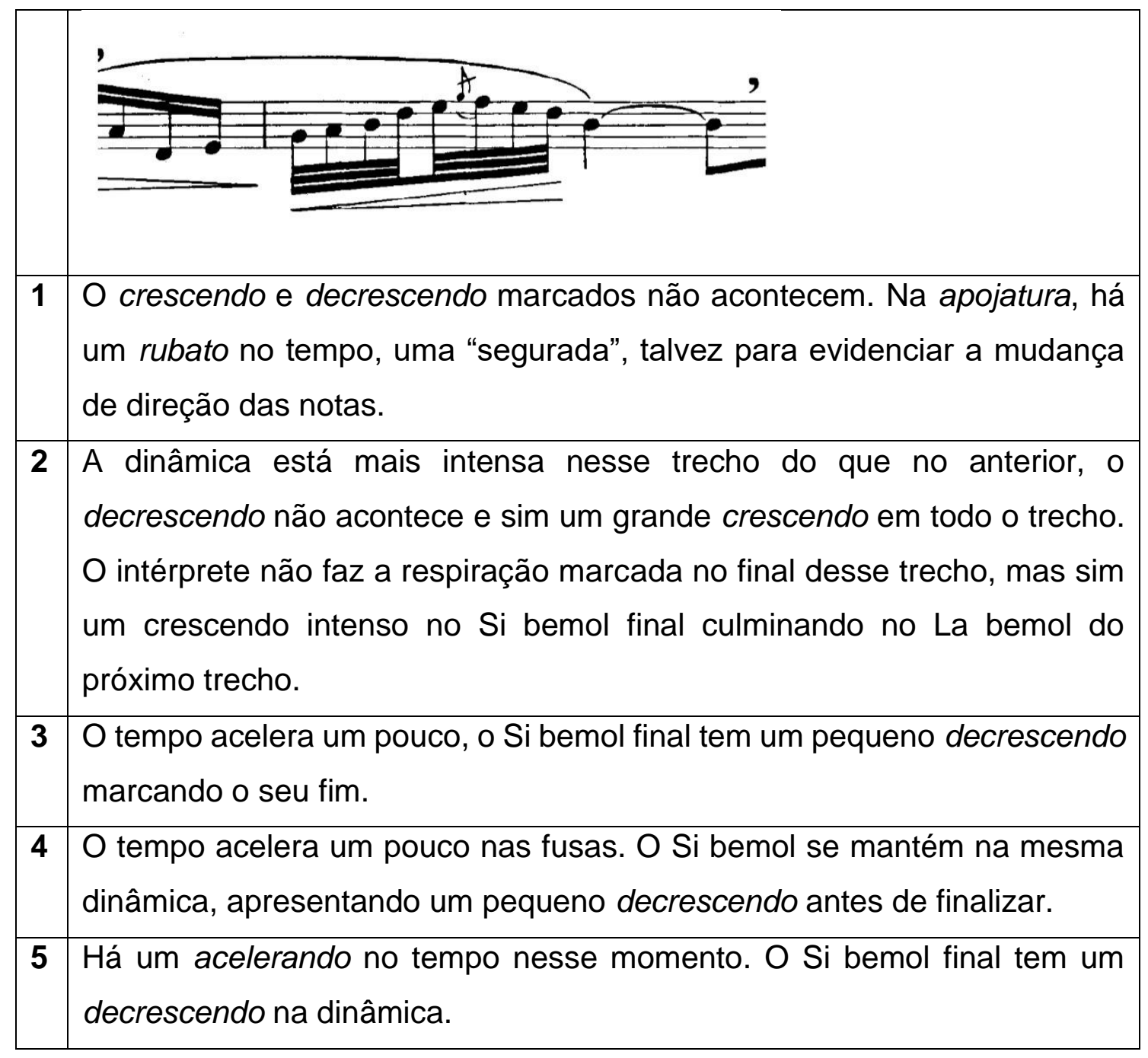

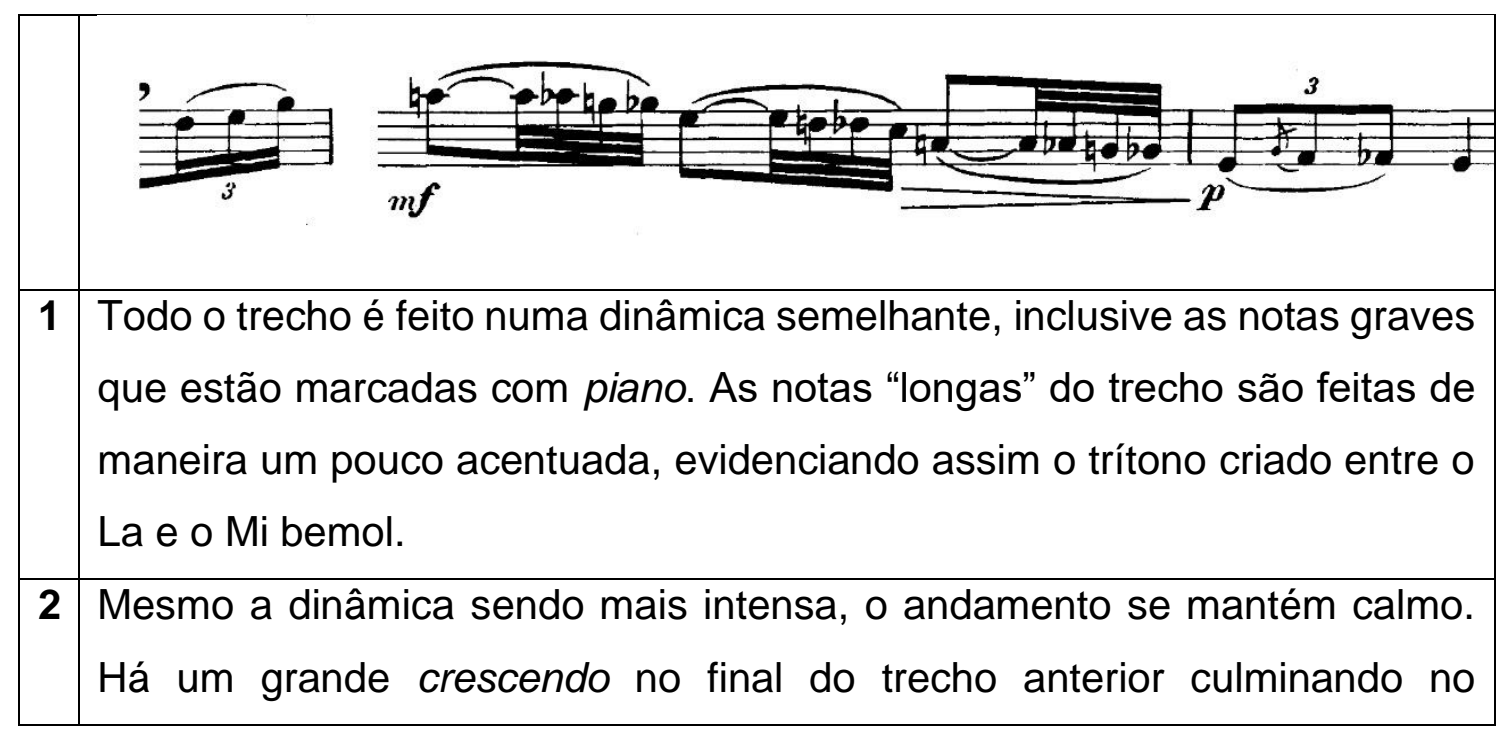




\begin{tabular}{|l|l|}
\hline & $\begin{array}{l}\text { mezzoforte marcado no início desse trecho. O decrescendo marcado } \\
\text { acontece. }\end{array}$ \\
\hline $\mathbf{3}$ & $\begin{array}{l}\text { Nesse trecho, o intérprete segue exatamente as marcações da partitura. O } \\
\text { tempo não varia e as dinâmicas acontecem como marcadas. }\end{array}$ \\
\hline $\mathbf{4}$ & $\begin{array}{l}\text { No segundo tempo do compasso, há um acelerando e no próximo } \\
\text { compasso o tempo volta bruscamente ao que era antes. }\end{array}$ \\
\hline $\mathbf{5}$ & $\begin{array}{l}\text { O tempo aqui está mais lento, as fusas são feitas com calma. As primeiras } \\
\text { notas têm vibrato mas ele diminui junto com a dinâmica no decrescendo. }\end{array}$ \\
\hline
\end{tabular}

\begin{tabular}{|l|l|}
\hline 1 & $\begin{array}{l}\text { As duas primeiras tercinas são feitas de maneira bem rápida e quase não } \\
\text { há mudanças na dinâmica. Na tercina marcada com cédez há uma } \\
\text { mudança de tempo e o compasso marcado com Rubato é feito todo de } \\
\text { maneira mais lenta e em dinâmica mais suave. As quatro últimas } \\
\text { colcheias são lentas, mostrando bem cada nota. }\end{array}$ \\
\hline $\mathbf{2}$ & $\begin{array}{l}\text { Na marcação de Cedez, o andamento fica mais lento e a dinâmica decresce } \\
\text { bastante. O Re marcado com piano no último compasso do trecho é feito } \\
\text { bem piano, sendo a parte mais piano de todo esse trecho. }\end{array}$ \\
\hline 3 & $\begin{array}{l}\text { Nas duas primeiras colcheias há um crescendo e depois disso um grande } \\
\text { decrescendo que dura o segundo compasso do trecho inteiro. As quatro } \\
\text { colcheias finais são feitas num andamento mais lento. }\end{array}$ \\
\hline $\mathbf{4}$ & $\begin{array}{l}\text { Nas duas primeiras tercinas há um pequeno acelerando e na marcação de } \\
\text { Cedez o intérprete segura bastante o tempo em todas as notas da tercina. } \\
\text { Na marcação de Rubato o andamento acelera, mas ainda está mais lento } \\
\text { do que estava no início do trecho. }\end{array}$ \\
\hline $\mathbf{5}$ & $\begin{array}{l}\text { Em cada tercina é possível ouvir um pequeno crescendo e depois um } \\
\text { decrescendo. Não há mudanças no andamento. }\end{array}$ \\
\hline
\end{tabular}




\begin{tabular}{|l|l|}
\hline $\mathbf{1}$ & $\begin{array}{l}\text { As primeiras notas são tocadas em dinâmica intensa, com uso de vibrato. } \\
\text { O primeiro Re bemol também é feito com vibrato intenso e o segundo, } \\
\text { oitava acima, com um vibrato um pouco mais suave. O decrescendo } \\
\text { acontece, mas a nota é cortada antes de se dissolver completamente. }\end{array}$ \\
\hline $\mathbf{2}$ & $\begin{array}{l}\text { A dinâmica desse trecho se inicia mais suave que o final do trecho anterior, } \\
\text { apesar de não haver marcação de piano após o crescendo que finaliza o } \\
\text { trecho anterior. Esse trecho é feito em dinâmica suave e em andamento } \\
\text { mais lento. A última nota decresce até o silêncio e nele há uma fermata. }\end{array}$ \\
\hline $\mathbf{3}$ & $\begin{array}{l}\text { O tempo aqui é um pouco mais lento, mas não muito. Os dois Rés bemóis } \\
\text { têm a presença de vibrato. }\end{array}$ \\
\hline $\mathbf{4}$ & $\begin{array}{l}\text { O intérprete não faz esse trecho em andamento mais lento e deixa para } \\
\text { fazer o decrescendo apenas no final da última nota. O vibrato continua } \\
\text { presente. }\end{array}$ \\
\hline $\mathbf{5}$ & $\begin{array}{l}\text { Esse trecho é feito em dinâmica bem suave e quase sem uso de vibrato. } \\
\text { O andamento diminui um pouco e as duas notas finais são feitas com } \\
\text { calma. }\end{array}$ \\
\hline
\end{tabular}

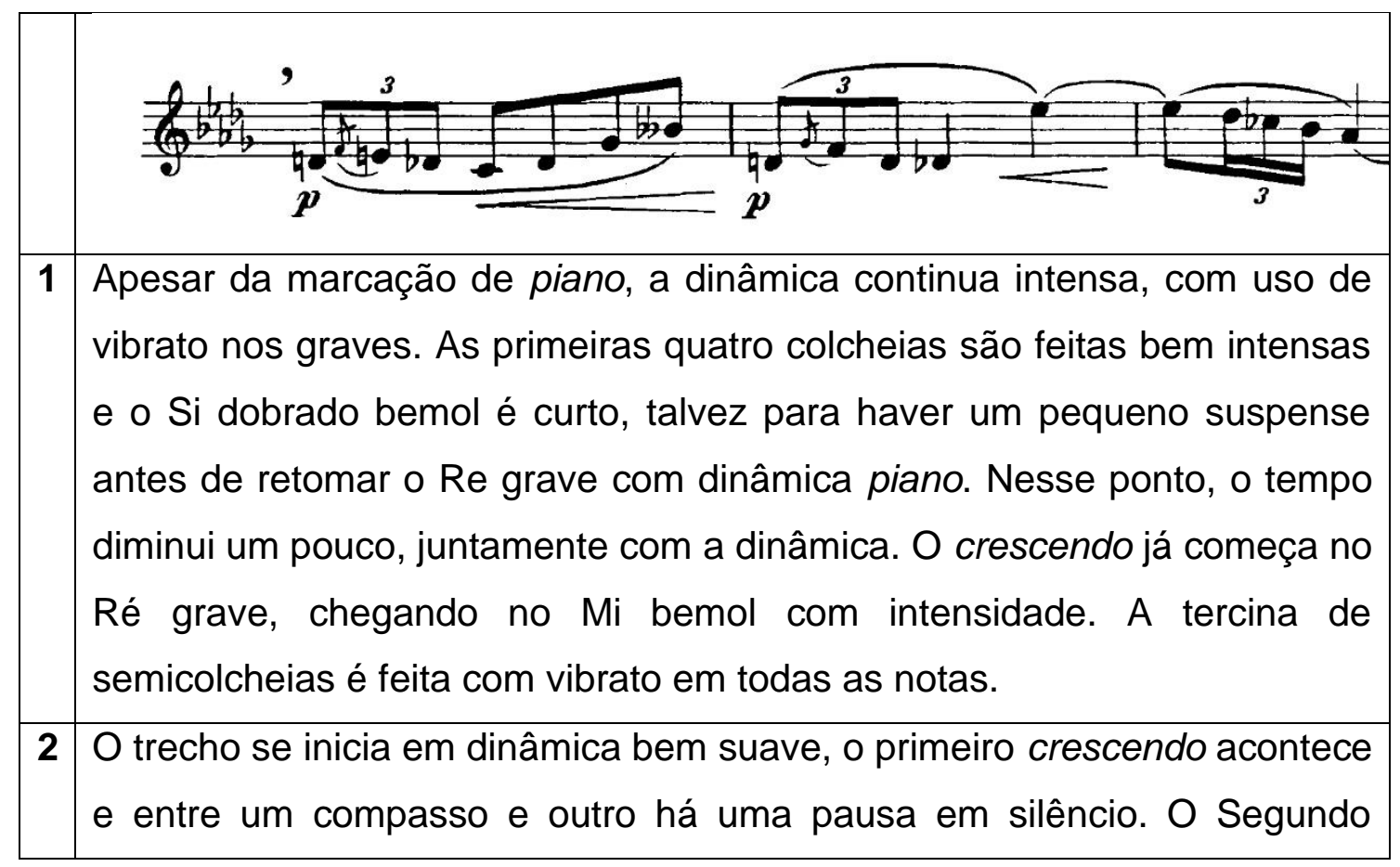




\begin{tabular}{|l|l|}
\hline & $\begin{array}{l}\text { compasso começa em dinâmica ainda mais suave e o crescendo seguinte } \\
\text { não é feito de forma tão rápida quanto o primeiro crescendo do trecho, mas, } \\
\text { acontece. }\end{array}$ \\
\hline $\mathbf{3}$ & $\begin{array}{l}\text { Entre o primeiro compasso do trecho e o segundo, há um pequeno } \\
\text { momento de silêncio, antecedendo o piano marcado. O segundo crescendo } \\
\text { acontece com intensidade. }\end{array}$ \\
\hline $\mathbf{4}$ & $\begin{array}{l}\text { A dinâmica aqui está mais suave, o vibrato aparece apenas no segundo } \\
\text { tempo do segundo compasso, mas some no início do Mi bemol do último } \\
\text { tempo, voltando a aparecer conforme a dinâmica cresce. }\end{array}$ \\
\hline $\mathbf{5}$ & $\begin{array}{l}\text { O crescendo marcado acontece, mas o piano seguinte não, apenas o } \\
\text { vibrato diminui de intensidade. O Mi bemol é mais forte desde o início. }\end{array}$ \\
\hline
\end{tabular}

\begin{tabular}{|l|l|}
\hline 1 & $\begin{array}{l}\text { No segundo Mi bemol, o intérprete segura o tempo, fazendo as quatro } \\
\text { semicolcheias seguintes num tempo mais lento que o início desse trecho. } \\
\text { Novamente, pode-se dizer que ele fez essa escolha para evidenciar a } \\
\text { mudança de direção das notas nesse ponto. }\end{array}$ \\
\hline $\mathbf{2}$ & $\begin{array}{l}\text { Há rubato no tempo desse trecho. Em geral, o andamento está um pouco } \\
\text { mais rápido. }\end{array}$ \\
\hline $\mathbf{3}$ & $\begin{array}{l}\text { O Mi bemol é feito de maneira bem marcada, ouve-se bem a separação } \\
\text { das ligaduras entre um compasso e outro. }\end{array}$ \\
\hline $\mathbf{4}$ & $\begin{array}{l}\text { As tercinas são feitas com rubato, e as quatro últimas semicolcheias com } \\
\text { um pequeno rallentando. }\end{array}$ \\
\hline $\mathbf{5}$ & $\begin{array}{l}\text { A dinâmica está mais intensa. A intérprete não faz a respiração marcada } \\
\text { no fim do trecho e sim um crescendo na nota indo até o próximo compasso. }\end{array}$ \\
\hline
\end{tabular}

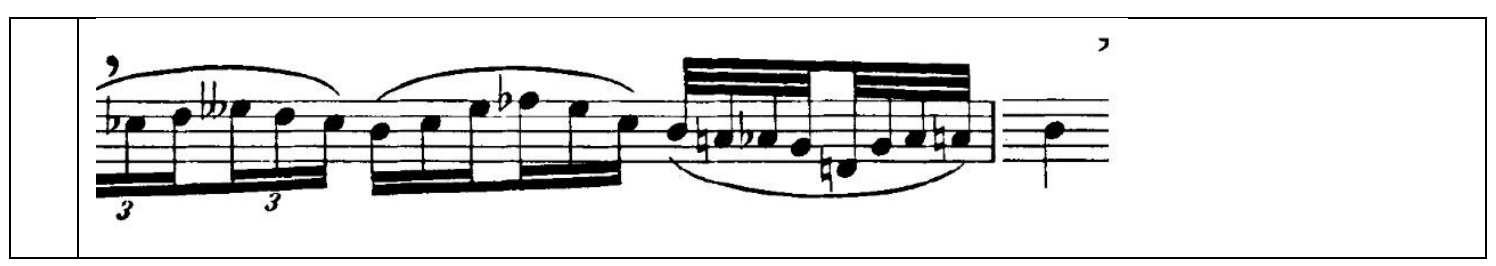




\begin{tabular}{|l|l|}
\hline $\mathbf{1}$ & $\begin{array}{l}\text { Nas primeiras quatro notas desse trecho, o intérprete faz um tempo mais } \\
\text { lento e em seguida faz um acelerando. Essa ideia pode ter surgido pois o } \\
\text { ritmo nesse trecho se agita com o surgimento das fusas. }\end{array}$ \\
\hline $\mathbf{2}$ & O tempo aqui continua acelerando um pouco. \\
\hline $\mathbf{3}$ & $\begin{array}{l}\text { O trecho se inicia em dinâmica mais suave e acontece um crescendo ao } \\
\text { longo do compasso. Há rubato e variações pequenas no tempo. }\end{array}$ \\
\hline $\mathbf{4}$ & Nas fusas há uma diminuição súbita na intensidade da dinâmica. \\
\hline $\mathbf{5}$ & O tempo e a dinâmica mantém-se nesse trecho. \\
\hline
\end{tabular}

\begin{tabular}{|l|l|}
\hline $\mathbf{1}$ & $\begin{array}{l}\text { O primeiro trillo é menos intenso que o segundo. O intérprete faz uma } \\
\text { respiração antes das apojaturas que antecedem o Si bemol e um grande } \\
\text { crescendo nele, muito intenso, com bastante uso de vibrato. A agitação } \\
\text { não aconteceu no trecho todo, e sim na nota longa. }\end{array}$ \\
\hline $\mathbf{2}$ & $\begin{array}{l}\text { O intérprete faz respirações no final de cada ligadura desse trecho, } \\
\text { causando uma impressão de intensidade, desespero. A dinâmica se } \\
\text { intensifica, a apojatura é feita de forma bem rápida e a nota longa final } \\
\text { cresce bastante enquanto a intensidade do vibrato também aumenta. }\end{array}$ \\
\hline $\mathbf{3}$ & $\begin{array}{l}\text { Há um crescendo na dinâmica desse trecho, culminando no Si bemol final, } \\
\text { que cresce e antes de haver a finalização, decresce rapidamente. }\end{array}$ \\
\hline $\mathbf{4}$ & $\begin{array}{l}\text { Há pausas feitas com calma entre cada ligadura. O Si bemol quase não } \\
\text { apresenta o crescendo, sua dinâmica já está intensa desde seu início e o } \\
\text { vibrato também. }\end{array}$ \\
\hline $\mathbf{5}$ & $\begin{array}{l}\text { O Si bemol final desse trecho não dura muito tempo. O andamento não } \\
\text { muda, não há nenhum acelerando, mesmo assim a nota final é feita de } \\
\text { maneira rápida e sem crescendo. }\end{array}$ \\
\hline
\end{tabular}

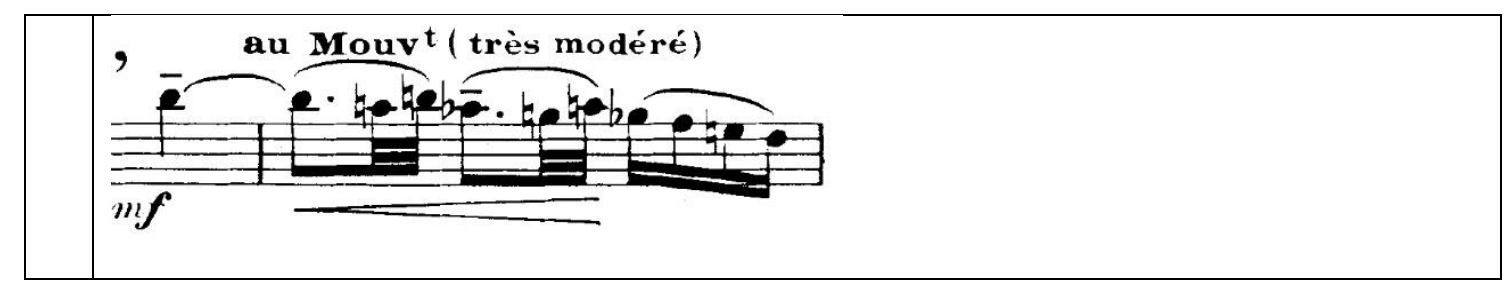


1 O primeiro Si bemol é feito numa dinâmica intensa, com bastante vibrato, dando continuidade ao $\mathrm{Si}$ bemol anterior a esse trecho. Não há espaço para o crescendo marcado, pois a dinâmica de todo o trecho já está extremamente intensa. As fusas são feitas com ênfase, demonstrando o caráter agitado que o intérprete está sugerindo.

2 Apesar da dinâmica estar bem intensa, o tempo aqui não acelera. $\mathrm{O}$ crescendo marcado não acontece muito, pois todo o trecho já está numa dinâmica intensa.

3 Não se ouve o crescendo marcado e após as quatro semicolcheias finais, existe uma pequena pausa em silêncio.

4 A dinâmica está mais intensa e o tempo parece um pouco mais lento. As fusas são bem pronunciadas. $O$ crescendo parece conduzir a frase até o próximo compasso.

5 A primeira nota é feita com bastante vibrato, a dinâmica está mais intensa, após as quatro semicolcheias há uma respiração.

\begin{tabular}{|l|l|}
\hline & $\begin{array}{l}\text { A dinâmica continua intensa, no Mi dobrado bemol há uma queda brusca } \\
\text { na velocidade do tempo, talvez para evidenciar a nota mais aguda da peça. } \\
\text { No diminuendo seguinte, o tempo subitamente acelera. }\end{array}$ \\
\hline $\mathbf{2}$ & $\begin{array}{l}\text { Há uma ênfase no Mi dobrado bemol, tanto em dinâmica quanto em tempo. } \\
\text { Na marcação de diminuendo, a dinâmica realmente diminui, juntamente } \\
\text { com o andamento, que se torna mais lento. }\end{array}$ \\
\hline $\mathbf{3}$ & $\begin{array}{l}\text { A dinâmica aqui está mais suave que no trecho anterior e no início do } \\
\text { segundo Si bemol já é possível ouvir o diminuendo. }\end{array}$ \\
\hline $\mathbf{4}$ & $\begin{array}{l}\text { O diminuendo marcado acontece acompanhado de um desacelerando do } \\
\text { tempo. }\end{array}$ \\
\hline $\mathbf{5}$ & $\begin{array}{l}\text { Após a fermata o tempo diminui e as notas são feitas com calma. O } \\
\text { dinimuendo marcado é feito juntamente com um desacelerando no tempo. }\end{array}$ \\
\hline
\end{tabular}




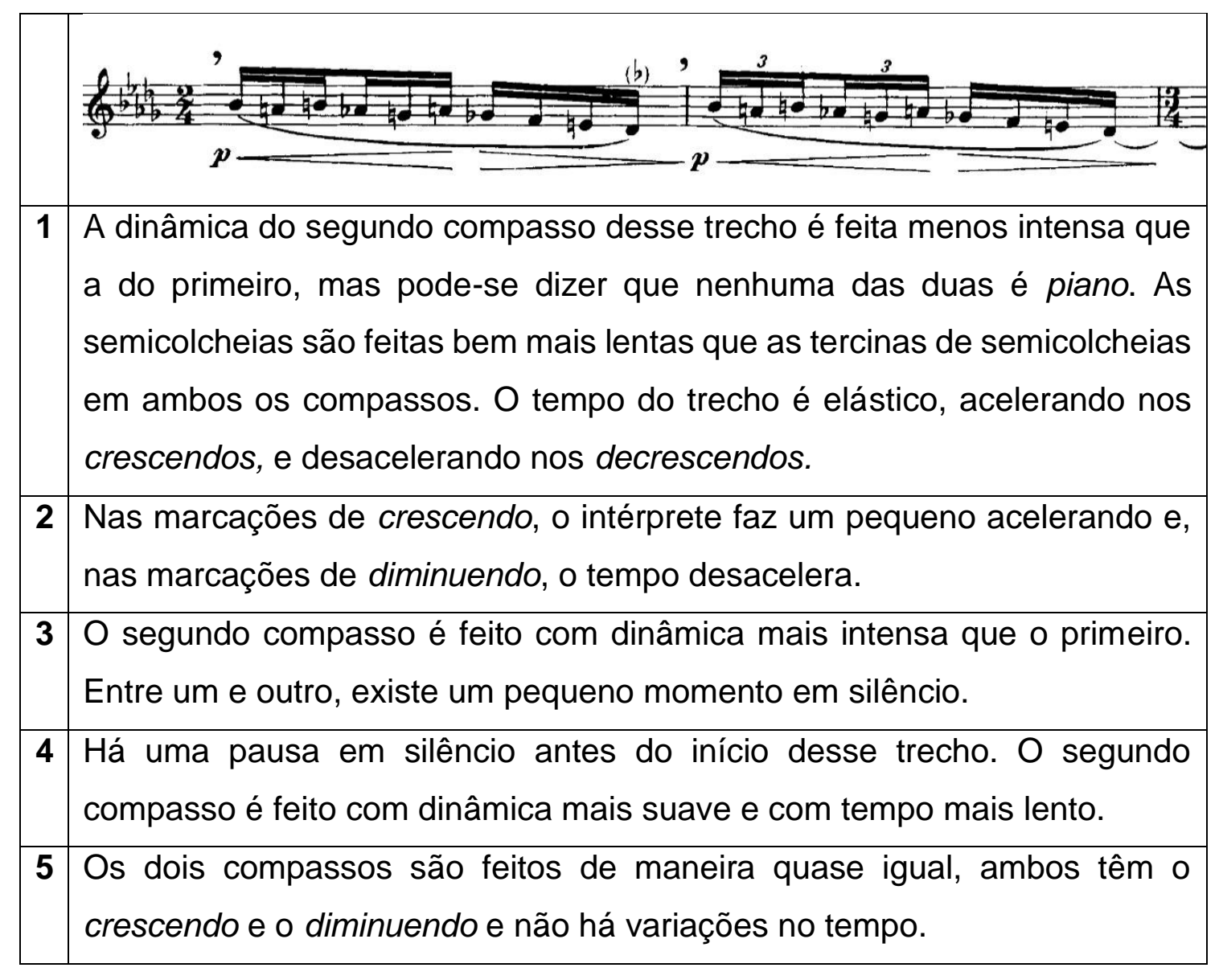

\begin{tabular}{|l|l|}
\hline 1 & $\begin{array}{l}\text { As tercinas são feitas lentas, mas a nota longa não acompanha a lentidão } \\
\text { sugerida por elas. A nota longa deveria ter sido muito mais longa } \\
\text { considerando o tempo lento que o intérprete iniciou o trecho. O La e o Sol } \\
\text { não são feitos com decrescendo. Todas as notas têm vibrato. }\end{array}$ \\
\hline $\mathbf{2}$ & $\begin{array}{l}\text { O andamento aqui está lento, as notas longas são realmente longas. No } \\
\text { Re bemol há um crescendo, culminando no La bequadro para depois haver } \\
\text { o diminuendo. }\end{array}$ \\
\hline $\mathbf{3}$ & $\begin{array}{l}\text { Todas as notas têm vibrato. Não existem grandes variações na dinâmica, } \\
\text { nem no tempo. }\end{array}$ \\
\hline $\mathbf{4}$ & $\begin{array}{l}\text { Parece haver um crescendo no Re bemol antes do decrescendo marcado. } \\
\text { Mesmo após o decrescendo, o Re bemol é feito com a dinâmica mais } \\
\text { intensa e com a presença de vibrato. }\end{array}$ \\
\hline
\end{tabular}


5 O Ré bemol grave é feito com um pouco de vibrato, as outras notas não. Há um diminuendo grande em todo esse trecho.

\begin{tabular}{|l|l|}
\hline 1 & $\begin{array}{l}\text { O início do Si bequadro é feito sem vibrato e o vibrato surge depois junto } \\
\text { com um crescendo. Depois disso, a dinâmica se mantém e as notas da } \\
\text { quintina são feitas todas com vibrato. O Re bemol final descrece, mas não } \\
\text { perde o vibrato, o vibrato acompanha o decrescendo até chegar no } \\
\text { silêncio. }\end{array}$ \\
\hline $\mathbf{2}$ & $\begin{array}{l}\text { O timbre inicial do Si bequadro é escuro, há um pouco de vibrato, mas não } \\
\text { muito. Logo após, a dinâmica decresce e o vibrato some. A escala } \\
\text { descendente é feita sem vibrato, lenta e a dinâmica bem suave. Na última } \\
\text { nota, a dinâmica decresce tanto, que quase não se consegue identificar o } \\
\text { final dela. }\end{array}$ \\
\hline $\mathbf{3}$ & $\begin{array}{l}\text { O Si bequadro se inicia com acento, dinâmica um pouco mais intensa que } \\
\text { o trecho anterior e sem vibrato. O vibrato aparece depois, talvez numa } \\
\text { maneira de se mostrar o acento marcado no início do segundo compasso } \\
\text { do trecho. O tempo diminui de andamento das duas colcheias que } \\
\text { antecedem a última nota e esta é feita com vibrato, em dinâmica suave, } \\
\text { com diminuendo. }\end{array}$ \\
\hline $\mathbf{4}$ & $\begin{array}{l}\text { A dinâmica aqui é mais suave, o timbre está mais escuro e não há a } \\
\text { presença de vibrato. Ele apenas aparece um pouco no Si bequadro, talvez } \\
\text { para evidenciar o acento marcado. A nota final decresce até o silêncio. }\end{array}$ \\
\hline $\mathbf{5}$ & $\begin{array}{l}\text { O Si bemol se inicia sem vibrato e depois o vibrato surge, mas não há um } \\
\text { aumento na dinâmica. Na quintina não há mais vibrato, a última nota é feita } \\
\text { também sem vibrato e diminui até chegar ao silêncio. }\end{array}$ \\
\hline
\end{tabular}

Tabela 3: quadro comparativo entre as gravações 


\section{Conclusão}

Interpretações de obras musicais não são únicas e definitivas e dependem de escolhas feitas pelo intérprete. As análises fornecem elementos que fundamentam novos aspectos de abordagem de uma obra, culminando em novas formas de interpretação. Uma interpretação não embasada por análises poderia deixar de lado alguns elementos importantes da obra musical.

As análises, porém, não impõem formas de interpretação, e sim sugestões, cabendo ao intérprete avaliar quais dessas sugestões ele pretende seguir e como pretende formular meios para praticá-las.

A escolha de timbres, o fraseado, a dinâmica, e até mesmo aspectos mais gerais da obra, como, por exemplo, o caráter, podem ser decididos através das análises. Certas passagens podem ser mais ou menos evidenciadas na execução de acordo com o modo que o intérprete entende as análises. Alguns pontos podem ter timbre mais claro ou escuro e pode haver variações no tempo, usando-se de recursos como rubatos para melhor salientar um elemento descoberto pelas análises.

A análise da performance, assim como análises para performance, evidencia diferentes maneiras de se interpretar uma obra, podendo assim, apontar sugestões para a formulação de uma interpretação. A audição de várias interpretações da mesma obra, se adicionada a outros tipos de análise, pode trazer benefícios na construção de uma nova interpretação, pois a observação de como diferentes intérpretes resolvem questões interpretativas funcionaria como um meio de criar um leque de opções para a escolha do intérprete.

Apesar de ter em mente que não é possível explicitar todos os dados colhidos através de análises em uma execução, cada análise demonstra um novo elemento, e, tendo esses elementos em mãos, o intérprete formularia mais coerentemente sua interpretação. 


\section{Referenciais Bibliográficos}

ABDO, S. Execução/Interpretação musical: uma abordagem filosófica. Per Musi. Belo Horizonte, v.1, p. 16-24. 2000.

ALMEIDA, A. Por uma visão de música como performance. Opus, Porto Alegre, v. 17, n. 2, p. 63-76. 2011.

ALMEIDA, G. A Análise Timbrística de Quatro Violões Através do Software Sonic Visualizer. Uberlândia. 2018.

BELLO, J.; CANNAN, C.; LANDONE, C.; SANDLER, M. The Sonic Visualiser: A Visualisation Platform for Semantic Descriptors from Musical Signals. Centre for Digital Music, Queen Mary University of London. Mile End Road, London, UK. 2006.

BOWEN, J. The History of Remembered Innovation: Tradition and Its Role in the Relationship between Musical Works and Their Performances. The Journal of Musicology, Vol. 11, n. 2, p. 139 - 173. 1993.

BULFINCH, T. Bulfinch's Mythology: The age of fable -- The age of chivalry Legends of Charlemagne. Public domain in the USA. (s/d).http://www.gutenberg.org/ebooks/4928

BULFINCH, Thomas. O Livro de Ouro da Mitologia - Histórias de Deuses e Heróis. Ediouro Publicações S/A, Rio de Janeiro, 2002.

CANNAN, C.; LANDONE, C.; SANDLER, M. Sonic Visualiser: An Open Source Application for Viewing, Analysing, and Annotating Music Audio Files. Copyright 2010 ACM 978-1-60558-933-6/10/10. 2010.

CARDOSO, A. Comparação de dinâmicas através do Sonic Visualiser. II Congresso da Associação Brasileira de Performance Musical Vitória/ES // ABRAPEM - UFES - FAMES. 2014.

CHADA, S. O Uso de Fontes Audiovisuais na Etnomusicologia: dois relatos de pesquisa. Associação Brasileira de Pesquisadores de História da Mídia ALCAR. Universidade Federal do Pará - Belém, PA. 2012.

COOK, N. Guide to Musical Analysis. Oxford University Press. 1994. 
COOK, N. Entre o Processo e o Produto: Música e/enquanto Performance. Per Musi, Belo Horizonte, n 14, p. 05 - 22. 2006.

D'AVILA, R. Syrinx. (s/d).<http://www.oocities.org/vienna/7787/syrinx.html>

DUNSBY, J. Execução e análise musical. Tradução de Cristina Magaldi. 1988.

EWELL, L. A Symbolist Melodrama: The Confluence of Poem and Music in Debussy's La Flûte de Pan. Morgantown, West Virginia. 2004.

LIEBMAN, E. ORNOY, E. CHOR, B. A Phylogenetic Approach to Music Performance Analysis. Journal of New Music Research. Vol. 41, nº 2, p. 215 242. 2012.

OVID. The Metamosphoses: Selected Stories in Verse. Dover Publications, INC, Mineola, New York, 2003.

PERSICHETTI, V. Twentieth century harmony: Creative aspects and practice. Nova York: Norton \& Company, 1961.

PLUTACH. Moralia. Kessinger Publishing, 2005.

RINK, J. Chopin's Ballades and the Dialectic: Analysis in Historical Perspective. Music Analysis, Vol. 13, No. 1, p. 99-115. Wiley. 1994.

RINK, J. Playing in time: rhythm, metre and tempo in Brahm's Fantasien Op. 116. 1995.

RINK, J. The Line of Argument in Chopin's E Minor Prelude. Early Music, Vol. 29, No. 3, p. 434-444. Oxford University Press. 2001.

RINK, J. Análise e (ou?) Performance. Cognição \& Artes Musicais / Cognition \& Musical Arts 2, p. 25-43. 2007.

RINK, J. Sobre a Performance, O Ponto De Vista Da Musicologia. Revista Música, v. 13, n 1, p. $32-60.2012$. 
RINK, J. The Work of the Performer. Virtual Works - Actual Things. Leuven University Press, p. $89-114.2018$

SALZMAN, E. Introdução à música do século XX. Zahar Editores, Rio de Janeiro, 1970.

SANTIAGO, D. Construção da performance musical: uma investigação necessária. Performance Online 2(1). 2006.

SCHMALFELDT, J. On Performance, Analysis, and Schubert. Per Musi, Belo Horizonte, v 5/6, p. 38 - 54. 2002.

STILLMAN, M. Debussy, Painter of Sound and Image. Flutist Quarterly, National Flute Association, Inc. 2007.

WINTER, L.; SILVEIRA, F. Interpretação e execução: reflexões sobre a prática musical. Per Musi, Belo Horizonte, n.13, p.63-71. 2006. 